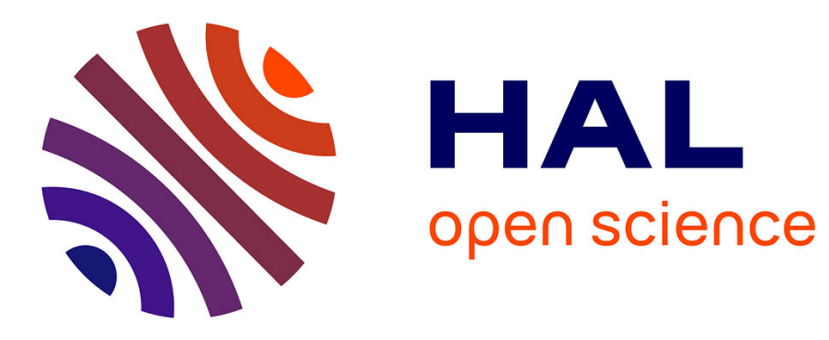

\title{
Endoplasmic reticulum dysfunction in neurological disease
}

\author{
Benoit D. Roussel, Antonina J Kruppa, Elena Miranda, Damian C Crowther, \\ David A Lomas, Stefan J Marciniak
}

\section{- To cite this version:}

Benoit D. Roussel, Antonina J Kruppa, Elena Miranda, Damian C Crowther, David A Lomas, et al. Endoplasmic reticulum dysfunction in neurological disease. The Lancet Neurology, 2013, 12 (1), pp.105 - 118. 10.1016/S1474-4422(12)70238-7 . inserm-01296824

\section{HAL Id: inserm-01296824 https://www.hal.inserm.fr/inserm-01296824}

Submitted on 1 Apr 2016

HAL is a multi-disciplinary open access archive for the deposit and dissemination of scientific research documents, whether they are published or not. The documents may come from teaching and research institutions in France or abroad, or from public or private research centers.
L'archive ouverte pluridisciplinaire HAL, est destinée au dépôt et à la diffusion de documents scientifiques de niveau recherche, publiés ou non, émanant des établissements d'enseignement et de recherche français ou étrangers, des laboratoires publics ou privés. 
Elsevier Editorial System(tm) for The Lancet Neurology

Manuscript Draft

Manuscript Number: THELANCETNEUROLOGY-D-12-00012R3

Title: IMPLICATIONS OF ENDOPLASMIC RETICULUM DYSFUNCTION IN NEUROLOGICAL DISEASE

Article Type: Review

Corresponding Author: Dr Benoit D Roussel, Ph.D.

Corresponding Author's Institution: INSERM U919

First Author: Benoit D Roussel, Ph.D.

Order of Authors: Benoit D Roussel, Ph.D.; Antonina J Kruppa, Ph.D.; Elena Miranda, Ph.D.; Damian C Crowther, Ph.D.; David A Lomas, Ph.D.; Stefan J Marciniak, Ph.D.

Abstract: Endoplasmic reticulum (ER) dysfunction is important in the pathogenesis of many neurological diseases. In this review, we examine the evidence for ER dysfunction in a range of neurological conditions including cerebral ischaemia, sleep apnoea, Alzheimer's disease, multiple sclerosis, amyotrophic lateral sclerosis, the prion diseases and Familial Encephalopathy with Neuroserpin Inclusion Bodies (FENIB). Protein misfolding in the endoplasmic reticulum initiates a well-studied 'Unfolded Protein Response' in energy-starved neurones during stroke that is relevant to the toxicity of reperfusion. The toxic peptide $A \beta$ induces 'ER stress' in Alzheimer's disease leading to activation of similar pathways, while the accumulation of polymeric neuroserpin in the neuronal ER triggers a poorly understood 'ER overload response'. In other neurological disorders such as Parkinson's and Huntington's diseases ER dysfunction is well recognised but the mechanisms for this are less clear. By targeting components of these signalling responses, it may prove possible to ameliorate their toxic effects and treat a range of neurodegenerative conditions. 


\section{IMPLICATIONS OF ENDOPLASMIC RETICULUM DYSFUNCTION IN NEUROLOGICAL DISEASE}

Benoit D. Roussel ${ }^{1,4} \mathrm{PhD}$, Antonina J. Kruppa ${ }^{1} \mathrm{PhD}$, Elena Miranda ${ }^{2} \mathrm{PhD}$, Damian C. Crowther ${ }^{3} \mathrm{PhD}$, David A. Lomas ${ }^{1} \mathrm{PhD}$ and Stefan J. Marciniak ${ }^{1} \mathrm{PhD}$

1'Department of Medicine, University of Cambridge, Cambridge Institute for Medical Research (CIMR), Wellcome Trust/MRC Building, Hills Road, Cambridge CB2 0XY, UK

2Department of Biology and Biotechnology 'Charles Darwin' and Pasteur Institute-Cenci Bolognetti Foundation, University of Rome 'La Sapienza', piazzale Aldo Moro 5, 00185 Rome, Italy

${ }^{3}$ Department of Genetics, University of Cambridge, Downing Site, Cambridge, CB2 3EH, UK

${ }^{4}$ INSERM U919, University Caen Basse Normandie, Serine Proteases and Pathophysiology of the Neurovascular Unit, Public Interest Group CYCERON, F-14074 Caen, France ( ${ }^{*}$ actual address)

Correspondence should be addressed to:

Dr Benoit D Roussel \& Dr Stefan J Marciniak

Cambridge Institute for Medical Research, Wellcome Trust/MRC Building,

Hills Road, Cambridge CB2 OXY, United Kingdom

Email: broussel@cyceron.fr, sjm20@cam.ac.uk 
Key words: ER stress, Neurodegeneration, Cerebral ischaemia, Alzheimer's disease, Parkinson's disease, FENIB

Running title: ER dysfunction in the CNS

Word count: 5,988 (excluding references and legends) 


\section{ABSTRACT}

Endoplasmic reticulum (ER) dysfunction is important in the pathogenesis of many neurological diseases. In this review, we examine the evidence for ER dysfunction in a range of neurological conditions including cerebral ischaemia, sleep apnoea, Alzheimer's disease, multiple sclerosis, amyotrophic lateral sclerosis, the prion diseases and Familial Encephalopathy with Neuroserpin Inclusion Bodies (FENIB). Protein misfolding in the endoplasmic reticulum initiates a well-studied 'Unfolded Protein Response' in energy-starved neurones during stroke that is relevant to the toxicity of reperfusion. The toxic peptide $A \beta$ induces 'ER stress' in Alzheimer's disease leading to activation of similar pathways, while the accumulation of polymeric neuroserpin in the neuronal ER triggers a poorly understood 'ER overload response'. In other neurological disorders such as Parkinson's and Huntington's diseases ER dysfunction is well recognised but the mechanisms for this are less clear. By targeting components of these signalling responses, it may prove possible to ameliorate their toxic effects and treat a range of neurodegenerative conditions.

Word count: 157 


\section{Introduction}

It can be argued that most neurodegenerative disorders arise from defective protein folding. This is clearly true for those rare disorders caused by the misfolding of mutated neuronal proteins such as Huntington's disease, but it is also the case for common disorders such as cerebral ischaemia where the lack of energy can impair normal protein folding ${ }^{1}$ and sporadic Alzheimer's disease where protein aggregation causes cellular stress ${ }^{2-4}$. Even some infectious neurodegenerative disorders such as the prionopathies arise from abnormal

protein folding ${ }^{5-9}$. Consequently, the processes for disposing of misfolded proteins are the focus of much research. Although the subcellular location of protein misfolding may differ between these disorders, it appears that the interdependence of protein folding throughout the cell results in ER dysfunction being the final common pathway for many, if not all, of these diseases (Table 1).

\section{ER Dysfunction}

The endoplasmic reticulum (ER) is required for folding of all secreted and membrane proteins and insults that impair its function induce a pathological state termed 'ER stress' ${ }^{10}$. This triggers an adaptive programme called the Unfolded Protein Response (UPR), which combines the early inhibition of protein synthesis with a later upregulation of genes that promote protein folding or disposal ${ }^{10}$. Both the translational and transcriptional components of the UPR protect the neurone from becoming overwhelmed by misfolded ER proteins; however, when the insult is too great, apoptotic cell death frequently ensues. While many cells 
are relatively protected from accumulating misfolded protein through continued dilution of their ER by cell replication, this process is unavailable to post-mitotic neurones, which depend exclusively on the UPR. Even glial cells, which can replicate, are susceptible to ER stress owing to their highly developed secretory pathway.

It is important that the UPR be distinguished from the less well-understood ER Overload Response (EOR) ${ }^{11}$. The former is triggered by protein misfolding within the ER lumen, while the latter occurs when well-folded or misfolded proteins accumulate and distend the ER. In this review, we will discuss the relevance of these forms of ER dysfunction to neurological disease, since a better understanding of each is likely to identify novel therapeutic strategies (Panel 1). We will focus on ischaemic stroke, Alzheimer's disease and Parkinson's disease to discuss ER stress, while using Familial Encephalopathy with Neuroserpin Inclusion Bodies (FENIB) to illustrate ER overload, since these are the diseases for which the most evidence currently exists. In addition, we will discuss the evidence for ER dysfunction in multiple sclerosis, amyotrophic lateral sclerosis and the prion disorders. Some neurological disorders provoke ER stress signalling despite being caused by the accumulation of protein within the cytoplasm, for example Huntington's disease ${ }^{12}$. Such disorders emphasise the interdependence of protein folding networks in the neurone and so shall be discussed as examples of disordered protein homeostasis or 'proteostasis'. 


\section{ER stress signalling}

The signalling pathways triggered by ER stress comprise the UPR ${ }^{10}$ (Figure 1 ). Although it may seem tiresome to dwell on individual molecular components, this is unavoidable when studying a phenomenon as complex as ER stress. Not least, because many of the measures commonly used to detect and quantify ER stress are themselves components of the UPR. Some of these are activated transiently and so their absence cannot be used as evidence for a lack of ER stress ${ }^{10,13}$; conversely, certain components can be activated by stresses other than ER protein misfolding and so need to be interpreted with caution. We shall therefore begin with a review of the major mediators of ER stress signalling with an emphasis on their role in neurones before moving on to considering specific examples of neuropathology mediated by ER dysfunction.

\section{- PERK}

Whenever misfolded protein accumulates in the ER lumen, new protein synthesis is rapidly inhibited ${ }^{14}$. This occurs because ER stress activates the PKR-like Endoplasmic Reticulum elF2 $\alpha$ Kinase (PERK), also know as Pancreatic elF2 $\alpha$ kinase (Pek) because of the tissue in which it was first discovered ${ }^{14}$. This kinase is ubiquitously expressed but is most important in highly secretory tissues such as the brain where it functions to match protein synthesis with the efficiency of protein folding in the ER ${ }^{15}$. When protein folding is progressing well PERK is inactive, but when misfolded ER proteins accumulate the kinase is activated and phosphorylates eukaryotic translation initiation factor $2 \alpha\left(\right.$ elF2 $\alpha$ ) (Figure 1) ${ }^{16}$. 
This substrate is a subunit of the heterotrimeric GTP-binding complex elF2 that regulates the initiation of protein synthesis ${ }^{14}$. EIF2 recruits the methionyl-tRNA to the ribosome at the onset of protein translation, but when its elF2 $\alpha$ subunit is phosphorylated this activity is lost and translation ceases. The load of proteins entering the ER is thus reduced following PERK activation preventing the accumulation of more misfolded proteins.

\section{- ATF4}

Despite the inhibition of protein translation that accompanies phosphorylation of elF2 $\alpha$, a small subset of mRNAs is translated more efficiently under these conditions ${ }^{17}$. The best characterised of these is Activating Transcription Factor 4 (ATF4), which triggers a transcriptional programme of stress-responsive genes

17. Other members of the elF2 $\alpha$ kinase family can inhibit translation and activate these genes; for example PKR responds to viral infection, HRI to iron deficiency and GCN2 to amino acid starvation ${ }^{18}$. This ability of elF2 $\alpha$ phosphorylation to mediate a response to multiple stresses led to this pathway being named the Integrated Stress Response ${ }^{19}$. Surprisingly, within the brain this can provoke specific behavioural responses. A lack of essential dietary amino acids triggers the phosphorylation of elF2 $\alpha$ in the anterior piriform cortex by GCN2, which alters feeding behaviour in rodents ${ }^{20,21}$. Thus, phosphorylation of elF2 $\alpha$ is not synonymous with ER stress and multiple lines of evidence should always be sought when attributing phosphorylation of elF2 $\alpha$ to ER dysfunction. 
Phosphorylation of elF2 $\alpha$ is particularly important for the maintenance of axonal myelination in the human central nervous system (Table 1); indeed mutations that disrupt the regulation of elF2 $\alpha$ result in white matter hypomyelination

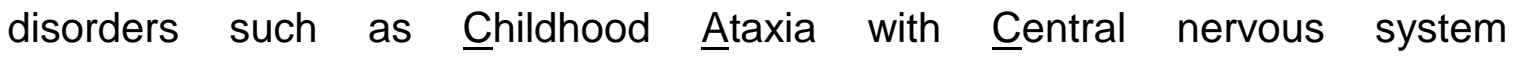
Hypomyelination (CACH syndrome) and Vanishing White Matter (VWM) ${ }^{22}$. This family of autosomal recessive conditions constitutes a spectrum of severity from congenital to adult-onset, involving the progressive loss of mental and motor function due to a loss of brain white matter. In all cases, the causative mutations are found within subunits of elF2B, a guanine nucleotide exchange factor (GEF) responsible for recharging the elF2 complex with GTP ${ }^{23,24}$ (Figure 1). These mutations interfere with the GEF activity of elF2B and enhance the synthesis of ATF4. This deregulates many target genes including components of a negative feedback system, including CHOP and GADD34, that normally recover protein translation following its initial inhibition by PERK ${ }^{13,25}$.

\section{- $\mathrm{CHOP}$}

The transcription factor CHOP is induced by ATF4 and has widely been thought to be pro-apoptotic during ER stress, since Chop-/- animals are resistant to ER stress-induced cell death ${ }^{13}$. However, this is inconsistent with observations made in neurological diseases. For example, CHOP expression is clearly antiapoptotic in mouse models of the X-linked disorder Pelizaeus-Merzbacher leukodystrophy caused by abnormalities of the proteolipid protein 1 (PLP1) gene

${ }^{26}$. Indeed, identification of the target genes of CHOP failed to reveal a link with 
apoptosis but instead identified genes that promote protein secretion ${ }^{13}$. This led us to suggest that in models of severe ER stress the promotion of protein secretion by $\mathrm{CHOP}$ might increase the intensity of stress and thus induce cell death ${ }^{13}$. By contrast, during conditions of milder ER stress, for example in Pelizaeus-Merzbacher leukodystrophy, it is likely that CHOP does not enhance ER stress sufficiently to trigger cell death ${ }^{26}$. These observations highlight the need to model not only the nature of the stress, but also its intensity and duration since differences in either can significantly affect the outcome and thus lead to beneficial or deleterious effects depending upon the context. There may also be cell type specific consequences of expressing CHOP. For example, while deletion of Chop worsens the central hypomyelination seen in PelizaeusMerzbacher leukodystrophy ${ }^{26}$, Chop-/- animals are protected against the peripheral hypomyelination caused by mutant myelin protein zero (P0) in mouse models of Charcot Marie Tooth type $1 \mathrm{~B}^{27}$.

\section{- GADD34}

A critical target gene of CHOP encodes Growth Arrest and DNA Damageinducible protein 34 (GADD34), which is a regulatory subunit of protein phosphatase $1(\mathrm{PP} 1)^{13}$. This dephosphorylates elF2 $\alpha$ and thus brings about the recovery of protein translation after its initial inhibition. It has been shown in mice that inactivation of the Gadd34 gene can protect animals from tissue damage during ER stress by reducing the accumulation of misfolded proteins ${ }^{13}$. Subsequently, a small molecule called salubrinal was identified that increases 
the level of elF2 $\alpha$ phosphorylation and promotes survival of ER-stressed cells ${ }^{28}$. It has been suggested that salubrinal may be an inhibitor of the elF2 $\alpha$ phosphatases ${ }^{28}$, but direct evidence for this is lacking. Recently, however, a selective inhibitor of GADD34, guanabenz, has been identified confirming the beneficial effects of GADD34 inhibition during ER stress at least in cultured cells 29. It is therefore likely that future therapies involving the inhibition of GADD34 will be able to modulate ER stress.

\section{- ATF6}

In addition to the Integrated Stress Response genes regulated by PERK and ATF4, many additional genes are induced during the UPR by two further ER stress sensors, Inositol-Requiring Enzyme 1 (IRE1) and Activating Transcription Factor 6 (ATF6) ${ }^{10}$ (Figure 1). Like PERK, both are ER membrane proteins that are held inactive under normal conditions by the binding of the ER chaperone Binding Immunoglobulin Protein (BiP; also known as GRP78). During stress, misfolded proteins sequester BiP, freeing ATF6 to traffic to the Golgi apparatus where it is cleaved to release a soluble transcription factor. Of note, astrocytes express an ATF6-related protein called OASIS (Old Astrocyte Specifically Induced Substance) whose functions appear to overlap partially with those of ATF6 ${ }^{30}$. This might enable astrocytes to respond to ER stress in a tissuespecific manner. 
While cleavage of ATF6 is strong evidence of ER stress, this is difficult to detect. Consequently, many studies fail to measure this arm of the UPR, but the use of sensitive reporters that measure the binding of ATF6 to specific DNA sequences can circumvent this problem in vitro ${ }^{11}$.

\section{- IRE1}

The activation of IRE1 closely resembles that of PERK but, unlike PERK, IRE1 triggers splicing of the mRNA encoding the transcription factor X-box Binding Protein $1(\mathrm{XBP} 1)^{31}$. This induces a frame shift that generates the active form of this protein. Like phosphorylation of elF2 $\alpha$, the splicing of XBP1 mRNA is transient ${ }^{13}$. Following the alleviation of ER stress by the induction of UPR target genes, spliced $X B P 1$ mRNA is rapidly lost from the cell to be replaced by the unspliced form ${ }^{13}$. In laboratory studies, supra-physiological levels of ER stress can cause complete splicing of XBP1 mRNA, but in vivo stresses are frequently subtler and so it is rare to observe complete splicing and careful quantification is therefore necessary ${ }^{32}$.

If proteins fail to fold in the ER, they are prevented from progressing along the secretory pathway and eventually are targeted for degradation ${ }^{33}$. This 'ERassociated protein degradation' (or ERAD) returns terminally misfolded proteins to the cytosol where they are ubiquitinated by ER-associated ubiquitin ligases for degradation by the proteasome ${ }^{34}$. Many components of the ERAD machinery 
are target genes of XBP1 and so the capacity for ERAD is increased by activation of IRE1 ${ }^{35}$.

\section{ER dysfunction in neurological disease}

\section{Cerebral hypoxia}

In industrialized countries stroke is the third biggest killer and the leading cause of disability in adults. Acute ischaemia is the main cause of neuronal loss and, although its pathology is complex, appears to involve ER stress ${ }^{1,15,36-38}$. During cerebral ischaemia, neuronal depolarization due to energy depletion causes the uncontrolled release of glutamate. The consequent activation of NMDA receptors on nearby neurones generates further glutamate release and causes an ischaemic depolarization wave to spread outward from the initial site of damage leading to widespread disturbance of calcium homeostasis ${ }^{39}$. Unsurprisingly, many studies implicate ER calcium store release in the resulting excitotoxic death (reviewed in reference ${ }^{39}$ ).

The ER is the main site for calcium storage within the cell and so its chaperones have evolved to function efficiently in this high calcium environment; indeed many require high calcium to function ${ }^{40}$. Calcium is pumped into the ER by the sarcoendoplasmic reticular calcium-ATPase (SERCA) and released back into the cytosol by the inositol trisphosphate receptor (IP3R) in response to extracellular signals and by the ryanodine receptor during calcium-induced calcium release ${ }^{39}$. Inhibition of the SERCA pump by thapsigargin induces apoptosis in many cell 
types including neuroblastoma cells and is often used to induce ER stress in the experimental setting ${ }^{41}$. During cerebral ischaemia, energy depletion leads to failure of the SERCA pump and thus redistribution of ER calcium into the cytosol. This delivers a double blow with combined toxicity from uncontrolled cytosolic calcium and ER stress due to chaperone dysfunction (Figure 2$)^{39}$.

The UPR is activated in many rodent models of cerebral ischaemia ${ }^{1,36}$. In these models, protein synthesis is rapidly inhibited and accompanies the phosphorylation of elF2 $\alpha$. Although the inhibition of translation has been attributed to aggregation of components of the translation machinery ${ }^{42}$, the primary mechanism appears to be through phosphorylation of elF $2 \alpha^{43}$, which can remain phosphorylated for up to twelve hours following ischaemia ${ }^{44}$. PERK is the sole elF2 $\alpha$ kinase activated by cerebral ischaemia and predictably Perk-/mice fail to show elF2 $\alpha$ phosphorylation following transient cerebral ischaemia and fail to reduce protein translation during the reperfusion period ${ }^{15}$. Even with the far milder recurrent cerebral hypoxia seen in obstructive sleep apnoea, activation of PERK has been described and has been suggested to play a role in the loss of upper airway motor neurones in this condition ${ }^{45}$.

IRE1 is also activated during cerebral ischaemia leading to the induction of UPR target genes ${ }^{37,38}$. It appears to promote activation of pro-apoptotic caspase-12 in cultured rodent cells and this has been detected in ischaemic rodent brains ${ }^{46}$. However, caspase-12 is non-functional in the majority of humans, except those 
from sub-Saharan Africa, owing to a common truncating mutation ${ }^{47}$. For this reason, it has been proposed that during ER stress in humans, caspase-4 might serve an analogous function to that of caspase-12 in rodents ${ }^{48}$.

Due to the problems of detection referred to earlier, the role of ATF6 during ischaemia is unclear. ATF6 gene expression is elevated following transient middle cerebral artery occlusion in rats ${ }^{36}$, but its activation has not been detected in rat brain following cardiac arrest and resuscitation ${ }^{49}$. OASIS is also upregulated and appears to play a neuroprotective role in response to kainate excitotoxicity ${ }^{50}$.

$\mathrm{CHOP}$ is induced following forebrain ischaemia in a variety of rodent models including bilateral common carotid ${ }^{51,52}$ or middle cerebral artery occlusion in mice ${ }^{44}$ and global cerebral ischaemia in rats ${ }^{53}$. The location within the brain of $\mathrm{CHOP}$ induction appears to correlate well with subsequent cell death ${ }^{53,54}$ and deletion of the Chop gene protects mice during bilateral common carotid artery occlusion ${ }^{52}$. Similarly, depletion of CHOP using RNA interference partially prevents the death of astrocyte cultures stressed by oxygen-glucose depletion ${ }^{55}$. As discussed, some of the toxicity attributable to $\mathrm{CHOP}$ reflects increased protein translation mediated by GADD34 ${ }^{13}$. Indeed, GADD34 induction is wellrecognised to accompany cerebral ischaemia ${ }^{56}$ being detected at the peri-infarct penumbra within two to twenty-four hours ${ }^{57}$ and accounts for the transient nature of elF2 $\alpha$ phosphorylation during stroke ${ }^{15}$. Attenuation of translation protects the 
cell from accumulating misfolded proteins, thus treatment with salubrinal (a drug that enhances elF2 $\alpha$ phosphorylation) reduces ER stress and promotes cellular survival in kainate-induced neurotoxicity ${ }^{58}$. Indeed, salubrinal has been shown to limit infarct size in a murine model of stroke ${ }^{1}$.

In addition to attenuating protein translation, the UPR leads to upregulation of ER molecular chaperones, the most abundant being BiP ${ }^{10}$. Following transient forebrain ischaemia, BiP expression in the hippocampus and cortex peaks between twelve to seventy-two hours after reperfusion ${ }^{54,59}$, but can remain elevated for up to two weeks ${ }^{36}$. This is protective, since suppression of BiP enhances apoptosis in hippocampal neurones exposed to excitotoxic and oxidative insults ${ }^{60}$, while its overexpression in primary astrocyte cultures is protective against oxygen-glucose deprivation ${ }^{61}$. Indeed, higher levels of BiP induction correlate with neuronal protection ${ }^{37,62}$.

Induction of the ER chaperone ORP150 (150-kDa oxygen-regulated protein) is also seen in ischaemic neurones, and over-expression of ORP150 protects mice from cerebral ischaemia ${ }^{63}$. ORP150 modulates the activity of BiP, which exists in either an ATP- or ADP-bound form, each with different substrate-binding affinity. ORP150 functions as a nucleotide exchange factor for BiP to replace its bound ADP with ATP. Interesting, another BiP nucleotide exchange factor, SIL1, is mutated in the Marinesco-Sjogren syndrome of cerebellar ataxia in which homozygous loss of SIL1 leads to ER stress and selective loss of cerebellar 
Purkinje cells ${ }^{64}$. When ATP-BiP binds its substrate protein, a co-chaperone of the DnaJ family is required to stimulate BiP's ATPase activity and so promote high affinity substrate binding. The relative levels of ADP-BiP and ATP-BiP appear to be important for neuronal survival, since the toxicity of SIL1 loss can be ameliorated by the deletion of an ER luminal DnaJ co-chaperone called p58 $8^{\mathrm{IPK}}$ 65. While loss of SIL1 would be predicted to reduce the level of ATP-BiP through impaired nucleotide exchange, loss of $\mathrm{p} 58^{\mathrm{IPK}}$ is likely to restore balance by lessening BiP's ATPase activity.

When taken together, these observations suggest that ER stress is induced by cerebral ischaemia and that the UPR limits cerebral infarct size. There is good evidence to suggest that manipulation of ER stress signalling by increasing phosphorylation of elF2 $\alpha$ may have important therapeutic effects as an acute intervention for cerebral ischaemia.

\section{Alzheimer's disease}

Often presenting with failing memory, Alzheimer's disease (AD) is a relentlessly progressive neurodegenerative disorder and the most common cause of dementia in adults. The classic histopathological features consist of extracellular plaques of the $\beta$-amyloid $(A \beta)$ peptide and intracellular neurofibrillary tangles of hyperphosphorylated aggregates of the microtubule-associated protein tau. Studies of familial AD demonstrate that the disorder is caused by overproduction of the more aggregation-prone $A \beta_{1-42}$ peptide ${ }^{66}$ (Figure 3). Despite decades of 
study, the molecular pathology of this disease remains unclear. However, increasing evidence suggests that ER stress may represent a new paradigm for understanding this condition.

Studies using post-mortem tissue from the brains of individuals with AD have provided evidence for ER dysfunction in this disease. But when looking at a single marker of ER stress, such studies can generate confusing results. For example, when BiP is examined in isolation it can show no change ${ }^{3}$, a decrease ${ }^{67}$ or even an increase ${ }^{2,68}$, although BiP expression does seem to be higher in brains with histologically more advanced disease ${ }^{68,69}$. However, whilst often a useful indicator, the level of $\mathrm{BiP}$ expression is inadequate alone to assess the activation of UPR signalling, especially in a chronic disorder in which histological features evolve over time. It has therefore proved more useful to include additional markers of the UPR in such studies. For example, protein disulphide isomerase, another target of the UPR, is elevated in the temporal lobes of the brains of individuals with $A D^{3}$, associated with neurofibrillary tangles in the hippocampus and frontal lobes and in dystrophic neurites of senile plaques ${ }^{4}$. When one looks for more proximal markers of UPR signalling, there is activation of PERK in the hippocampus of AD brains, which appears to co-localise with staining for phosphorylated tau and correlates with histological staging ${ }^{70,71}$. Yet phosphorylated PERK is barely detectable in tangle-bearing neurones themselves, suggesting that PERK is activated at the pre-tangle stage in neurones of the hippocampus ${ }^{71}$. In addition, there are elevated levels of spliced 
$X B P 1$ mRNA in the temporal cortex of $A D$ patients when compared to agematched controls ${ }^{3}$. Congruently, a marked increase in the number of neurones immunoreactive for phosphorylated (active) IRE1 $\alpha$ has been detected in the hippocampus of individuals with $A D^{71}$.

There is good evidence for activation of PERK in laboratory models of AD. Increased BiP expression observed upon application of exogenous $A \beta$ to primary cortical neurones suggests that accumulation of the peptide may directly activate ER stress signalling ${ }^{72,73}$. Moreover, exogenous $A \beta$ has been found to increase the phosphorylation of PERK and elF2 $\alpha$ in cultured neuronal cells ${ }^{73,74}$, while silencing of PERK by siRNA in $A \beta_{42}$-treated cells limits elF2 $\alpha$ phosphorylation and enhances cell death ${ }^{73}$. In addition, $A \beta_{42}$ treatment induces $\mathrm{CHOP}$ expression both in cultured cells and in rabbit hippocampus ${ }^{75,76}$, while prior treatment of cells with $\mathrm{CHOP}$ anti-sense RNA improves survival following exposure to the $A \beta$ peptide, suggesting a role for $C H O P$ in $A \beta$-mediated death ${ }^{77}$. In Drosophila neurones or mammalian PC-12 cells, exposure to $A \beta$ induces XBP1 mRNA splicing and in both models overexpression of spliced XBP1 is protective, while knockdown of XBP1 exacerbates $A \beta$ toxicity ${ }^{78}$.

PC-12 cells overexpressing mutant forms of presenilin 1 (PS1), a component of the $\gamma$-secretase, that has been linked to familial $A D$, show increased levels of phosphorylated elF2 $\alpha$, as do hippocampal homogenates from PS1 mutant knock-in mice ${ }^{79}$. PC-12 cells expressing mutant PS1 have elevated levels of 
CHOP, as do knock-in mice expressing mutant PS1 ${ }^{79}$. The nature of the interaction between PS1 and ER stress has yet to be fully elucidated, although it is known that PS1 and the SERCA calcium pump physically interact with one another ${ }^{80}$. As discussed, disordered calcium homeostasis is a potent cause of ER stress and much evidence suggests that calcium signalling is perturbed in Alzheimer's disease ${ }^{81}$ (reviewed in reference ${ }^{82}$ ). Interestingly, ER stress induced by tunicamycin, a glycosylation inhibitor frequently used to induce ER stress in vitro, increases PS1 expression in multiple cell lines including neuroblastoma ${ }^{80}$. Recent evidence suggests that phosphorylation of elF2 $\alpha$ by PERK during ER stress can increase the level of $\beta$-site APP cleaving enzyme-1 (BACE) and thereby promoting amyloid formation ${ }^{83}$. This suggests that the interaction between $A D$ and ER stress may prove to be bi-directional.

ER stress has been shown to alter APP localization, processing and degradation by the ERAD machinery ${ }^{84}$ (Figure 4). During ER stress, immature forms of APP bind to $\mathrm{BiP}$ and when $\mathrm{BiP}$ is overexpressed $\mathrm{A} \beta$ generation is reduced as APP is retained in earlier compartments of the secretory pathway ${ }^{84}$. The ERAD ubiquitin ligase HRD1 promotes APP ubiquitination and degradation in HEK293 cells reducing the generation of both $A \beta_{40}$ and $A \beta_{42}{ }^{2}$. In addition, an intronic polymorphism (IVS3-88A $>$ G) of $S E L 1 L$, another component of the ERAD system, has been associated with $A D$ in an Italian population ${ }^{85}$. These hints that ERAD is important in the pathogenesis of $A D$ still require further validation. But there is accumulating evidence for elevated UPR signalling in AD and, combined with the 
support from model systems, provides a potential mechanism by which the $A \beta$ peptide and mutants of PS1 might induce ER stress. This offers the potential to identify new therapeutic targets in an otherwise incurable disease.

\section{Parkinson's disease}

With age, $2 \%$ of the population suffer the loss of dopaminergic neurones in their nigrostriatal pathway and so develop Parkinson's disease (PD) characterised by hypokinesia, rigidity and tremor. Post-mortem studies identify characteristic Lewy body inclusions in many affected brains, suggesting aberrant protein disposal as a possible cause, while toxins that cause Parkinsonism, such as MPTP, rotenone and 6OHDA, impair mitochondrial function and promote ER stress ${ }^{86-90}$.

Multiple lines of evidence point towards a role for ER stress in the pathogenesis of PD. For example, excess levels of dopamine are toxic to PC-12 cells, which correlates with their induction of ER chaperones ${ }^{91}$. The brains of patients suffering from sporadic PD, but not controls, have elevated levels of phosphorylated PERK and elF2 $\alpha{ }^{92}$. Perk-/- sympathetic neurones are hypersensitive to $6 \mathrm{OHDA}{ }^{92}$, while overexpression of spliced XBP1 is protective both in cultured cells and animals treated with MMP+/MPTP ${ }^{87}$. CHOP expression is increased both by 6OHDA and MPTP, and knockout of the Chop gene is protective in mice treated with 6OHDA ${ }^{93}$. 
In Japanese and European families with the juvenile onset autosomal recessive variant of PD (ARPD), classical genetic mapping identified the diseaseassociated gene PARK2 ${ }^{94}$. This encodes an ubiquitin ligase Parkin, whose activity is lost with disease-associated mutations ${ }^{95}$. Parkin was suggested to localize to the ER and to be upregulated during the UPR ${ }^{96}$. A major function of Parkin appears to involve targeting defective mitochondria for destruction by autophagy ${ }^{97}$. It is possible that impaired mitochondrial function in patients with PARK2 mutations manifests as ER stress owing to defects in energy supply during ER protein folding. However, another component of Lewy bodies, $\alpha-$ synuclein, can be found throughout the cell including the ER lumen and may also be a target of Parkin ${ }^{98}$. Mutations of $\alpha$-synuclein cause an autosomal dominant form of PD ${ }^{99}$, while the glycosylated ER-form of $\alpha$-synuclein has been shown to be ubiquitinated by Parkin and to accumulate in a non-ubiquitinated form in the brains of individuals with Parkin deficiency ${ }^{98}$. Overexpression of $\alpha$-synuclein induces ER stress ${ }^{100}$, perhaps through binding to $\mathrm{BiP}{ }^{101}$, while PDI appears to impair $\alpha$-synuclein fibril formation ${ }^{100}$. Recently, oligomers of mutant $\alpha$-synuclein were shown to accumulate within the ER in an animal model and to trigger the UPR, albeit with relatively little PERK activation ${ }^{102}$. When elF2 $\alpha$ phosphorylation was augmented with salubrinal, the accumulation of $\alpha$-synuclein oligomers was ameliorated and disease onset was delayed. There is further evidence that modulating the levels of ER stress may be beneficial in PD, since 4-PBA, which has been shown to possess 'chemical chaperone activity' that can protect cells from ER stress, rescues cells from the neurotoxicity of rotenone ${ }^{103}$ and 'pre- 
conditioning' neuroblastoma cells with ER stress to up-regulate chaperone levels can protect the cells from subsequent challenge with 6OHDA ${ }^{104}$.

\section{Huntington disease}

Huntington disease (HD) is an inherited autosomal dominant disorder characterised by motor dysfunction, psychiatric disturbances and intellectual decline. It is caused by expansions of CAG repeats within the HTT gene encoding huntingtin and so represents an archetypal poly-Q disease. In health, the normal HTT gene contains 6 to 35 repeats, while in patients affected by HD there may be more than 40 , which generates a protein prone to aggregation. Although this aggregation takes place in the cytosol this has been shown to provoke ER stress ${ }^{105}$.

It is now appreciated that perturbations of protein folding within one organelle can be propagated to another. This concept of cell-wide protein homeostasis, or 'proteostasis', may be especially relevant to HD and other poly-Q disorders wherein cytoplasmic aggregates trigger the UPR ${ }^{106}$. The precise mechanism linking aggregation in the cytosol with malfunction of the ER is poorly understood; however, expression of poly-Q proteins and mutant huntingtin in cells has been shown to bind components of the ERAD machinery and impair their function ${ }^{12}$, 107. It is possible that huntingtin is a target of the ERAD ubiquitin ligase HRD1,

since HRD1 can ameliorate the toxicity of the poly-Q protein ${ }^{107}$. By sequestering HRD1 and other components, huntingtin might reduce the capacity of a neurone 
to cope with misfolded proteins by ERAD, thereby rendering them more vulnerable to ER stress ${ }^{12}$. In addition, while chronic ER stress is known to induce cell death in some circumstances, it might also impair intracellular signalling in viable cells. Recent data suggest that ER calcium release via the IP3R1 channel is impaired by ER stress in HD owing to the loss of a stimulatory interaction between $\mathrm{BiP}$ and this channel ${ }^{108}$.

\section{Amyotrophic lateral sclerosis}

Amyotrophic lateral sclerosis (ALS) involves the progressive loss of motor neurones causing an irreversible decline of muscle power and death usually within five years. The aetiology remains largely unknown, although $5-10 \%$ of cases display a dominant pattern of inheritance suggestive of a toxic-gain-offunction, so-called Familial ALS (FALS). Of these, a fifth are caused by mutations in the copper-zinc superoxide dismutase 1 (SOD1) that accumulates as fibrils in Lewy Body-like hyaline inclusions, the histological hallmark of FALS.

Post-mortem brains from ALS patients show elevated levels of markers of ER stress ${ }^{109}$. Furthermore, disease models of FALS implicate ER stress in its pathogenesis. Although SOD1 was thought to be an abundant cytosolic protein, it is also secreted by multiple cell types and co-localises with ER markers ${ }^{110}$. When expressed in cultured cells or in animal neuronal tissue, mutant SOD1 accumulates within the ER and upregulates targets of the UPR ${ }^{111-113}$. 
Activation of PERK can be detected in animals prior to the development of overt disease ${ }^{114}$ and it has been shown in three models of FALS that a subset of motor neurones are more sensitive to the toxic effects of mutant SOD1 and show evidence of ER stress at a younger age ${ }^{115}$. When one allele of Perk is deleted in mice expressing a mutant form of SOD1, onset of disease is accelerated, suggesting that phosphorylation of elF2 $\alpha$ is protective in this disorder ${ }^{116}$. This is supported by the protection of vulnerable neurones in animals treated with salubrinal ${ }^{115}$.

Surprisingly, deletion of neuronal XBP1 has been shown to delay the onset of disease extending the lives of FALS mice ${ }^{117}$. In cultured neurones depletion of XBP1 reduces SOD1 aggregates and toxicity through enhanced autophagy, which might plausibly explain this apparent neuroprotection through increased clearance of aggregated protein. Similarly, enhanced degradation of SOD1 by overexpression of ERAD protein derlin1 ameliorates SOD1-induced cell death 118. Though mutant SOD1 has been shown to interact with derlin1 and so impair ERAD to promote ER stress ${ }^{119}$.

\section{Multiple sclerosis}

Regulated phosphorylation of elF2 $\alpha$ is important for the health of myelinated neurones within the central nervous system as illustrated by the $\mathrm{CACH} / \mathrm{VWD}$ syndrome and Pelizaeus-Merzbacher leukodystrophy as mentioned previously. This holds true in multiple sclerosis (MS), although the timing of elF2 $\alpha$ 
phosphorylation relative to the onset of disease determines its consequences. In the experimental autoimmune encephalitis (EAE) model of MS, ER stress can hasten or delay disease progression if induced after of before disease onset respectively ${ }^{120,121}$; a phenomenon previously seen with interferon treatment. Indeed, both EAE and interferon cause phosphorylation of elF2 $\alpha$ by PERK. Only when animals are exposed to interferon prior to EAE is a protective 'preconditioning' seen and, importantly, the protection is lost if one allele of Perk is deleted ${ }^{120}$. In contrast, interferon treatment of animals with established EAE exacerbates their ER stress and worsens demyelination through impaired oligodendrocyte survival.

\section{FENIB}

Ten years ago, the first cases of a new familial encephalopathy with inclusion bodies (FENIB) were described in two families living in the USA ${ }^{122}$. The primary symptom of this autosomal dominant neurodegenerative disease was pre-senile dementia. In each family, eosinophilic neuronal inclusions were observed in the deeper layers of the cerebral cortex and in the substantia nigra (Figure 5). After isolation and sequencing of these inclusions, it was demonstrated that they were composed of a single protein, neuroserpin. When expressed in neurones, the mutants of neuroserpin accumulate to form acid-Schiff-positive diastase-resistant inclusions in the ER, also called Collins' bodies ${ }^{122}$. 
Neuroserpin is a member of the serine protease inhibitor (serpin) superfamily. Serpins are capable of polymerisation under certain circumstances and many examples of naturally occurring mutations exist that promote polymerisation leading to disease ${ }^{123,124}$. The retention of polymerised neuroserpin within the ER causes neurotoxicity through a toxic gain-of-function, while the lack of secretion causes the activation of proteolysis and hence disease through a lossof-function ${ }^{123}$.

Despite being retained in the ER, the polymerised mutants of neuroserpin fail to activate the UPR ${ }^{11}$. Instead, these polymers induce NFKB signalling in a calcium-dependent manner ${ }^{11}$. This is reminiscent of the ER overload response (EOR), which is activated by the accumulation of well-folded protein as happens, for example, in some viral infections ${ }^{125}$. The degradation of mutant neuroserpin involves the co-ordinated activity of both the ERAD and autophagic pathways ${ }^{124}$. Since these pathways have successfully been targeted in preclinical studies of a related serpinopathy using the drug carbamazepine ${ }^{126}$, there is hope for pharmacological treatment of this and other ER overload disorders. Indeed, it is likely that similar strategies will prove beneficial in other diseases of protein accumulation, such as those described in the sections concerning ER stress.

\section{Prion diseases}

The nature of the ER dysfunction observed in prion diseases remains less clear. While ER stress pathways were activated in a cell model of Creutzfeldt-Jakob 
disease (CJD), UPR signalling was not detected in a transgenic mouse model for prion disease ${ }^{5}$. Nevertheless, both primary neuronal cultures and PC-12 cells expressing PrP mutants develop dramatic ER swelling suggesting that ER homeostasis is perturbed ${ }^{6}$. The failure to detect splicing of XBP1 mRNA or differences in BiP levels in prion disease models suggests that prion proteins might not elicit classical ER stress ${ }^{5}$. However, pharmacological induction of ER stress in neuronal cell lines expressing mutant PrP can decrease PrP levels ${ }^{7}$. Recently it was shown that prion replication causes prolonged repression of protein translation leading to synaptic failure of neuronal loss ${ }^{9}$. In contrast to many ER stress-related disorders in which enhanced phosphorylation of elF2 $\alpha$ is protective, prion-induced neurodegeneration is enhanced by salubrinal while overexpression of GADD34 is protective. The relationship between the prionopathies and ER dysfunction therefore requires further examination.

\section{Concluding remarks and therapeutic potential}

The evidence for activation of ER stress responsive pathways in a range of neurological conditions is strong. What remains to be determined is how successful strategies that target these responses will be in treating these

diseases. The UPR signalling field has matured to a point at which small molecular inhibitors of its components are now being developed.

The muscle relaxant dantrolene targets IP3R channels of the ER to prevent the release of calcium. This provides neuroprotection in models of HD ${ }^{127}$ and of 
cerebral hypoxia-reperfusion injury, where its action is associated with reduced levels of ER stress ${ }^{128}$. Prolonging the phosphorylation of elF2 $\alpha$ and thus delaying the recovery of protein translation with agents such as salubrinal or guanabenz is another promising approach ${ }^{28,29}$. Salubrinal has already been shown to reduce the accumulation of $\alpha$-synuclein in models of $A L S^{102,129}$, reduce the toxicity of $A \beta$ to primary neurones ${ }^{73}$, and lessen the ER stress associated with cerebral ischemia/reperfusion and models of $\mathrm{HD}{ }^{1,}{ }^{130}$. More recently, agents have been developed that inhibit IRE1, including quinotrierixin ${ }^{131}$ and $4 \mu 8 \mathrm{C}{ }^{132}$. Both selectively inhibit the splicing of XBP1 mRNA and the latter prevents expansion of the ER without obvious toxicity, which might have therapeutic utility to impede the formation of protein inclusions in neurones.

The list of neurological disorders with impaired ER protein folding is already long and appears set to grow further for some time to come (Table 1). It will therefore aid the neurologist and neuroscientist alike to appreciate the signalling pathways that communicate this failure of ER function to the rest of the cell, since it is likely these insights will inform research, diagnosis and ultimately therapy.

\section{Acknowledgements}

Our labs are funded by grants from the MRC and ART and by Papworth NHS Trust. AJK is a Wellcome Trust PhD student and SJM is an MRC Senior Clinical Fellow (MRC Ref G1002610). DCC is an Alzheimer's Research UK Senior Research Fellow and is supported by the MRC and EPSRC (MRC Ref 
G0700990). EM is funded by the Pasteur Institute-Cenci Bolognetti Foundation and by the Telethon Foundation.

\section{Contributions and conflicts of interest}

BDR and SJM planned and wrote the review. All authors commented on the final manuscript. BDR performed the literature search for and wrote the stroke, Parkinson's and Huntington's disease, multiple sclerosis and prionopathy sections and prepared figure 1. AJK performed the literature search for Alzheimer's disease, and contributed to drafting the Alzheimer's disease section and figure. EM helped draft the FENIB section. DCC helped draft the Alzheimer's section. DAL helped draft the FENIB section. SJM performed the literature search for ER stress and supervised the review project. 


\section{Panel 1}

\section{Search Strategy}

We set out by searching the PubMed database with the terms "(endoplasmic reticulum) AND (brain OR neurological) AND disease" including only articles in English. These titles and abstracts were screened and relevant papers were obtained for detailed assessment. Their bibliographies were also screened for additional sources. Papers published prior to September 2012 are included. Where possible, emphasis is given to articles published within the last 5 years.

\section{Figure legends}

Figure 1. Endoplasmic reticulum stress signalling In health, newly synthesised secretory proteins are translocated into the ER lumen co-translationally. They fold with the aid of chaperones, for example BiP. When recognised as correctly folded they exit the ER in COPII-coated vesicles and traffic along the secretory pathway. During ER stress, misfolded proteins accumulate in the ER lumen and sequester BiP from the sensor molecules PERK, IRE1 and ATF6. PERK phosphorylates elF2 $\alpha$, which binds and inhibits its guanine nucleotide exchange factor elF2B. This blocks new secretory protein synthesis and triggers the integrated stress response (ISR) through increased levels of ATF4. Activation of IRE1 leads to generation of active XBP1, while 
cleavage of ATF6 generates ATF6c. These transcription factors co-operate to induce target genes of the unfolded protein response (UPR).

\section{Figure 2. ER stress during cerebral ischaemia}

During an ischaemic stroke, the lack of glucose and oxygen supply in neurones induces a dramatic fall in ATP production. Without energy, BiP binds to unfolded proteins less efficiently resulting in the accumulation of misfolded ER client proteins and subsequent activation of the UPR. In parallel, failure of the SERCA pump depletes ER calcium and worsens chaperone function still further. Extracellular tPA (tissue-type plasminogen activator) cleaves the NMDA receptor allowing calcium influx into the cytosol. The resultant elevation of cytosolic calcium triggers calcium-induced calcium release via ryanodine receptors located in the ER membrane leading to calcium depletion from the ER. In severely affected neurones, elevated cytosolic calcium ultimately induces cell death. In surviving neurones, induction of the elF2 $\alpha$ phosphatase GADD34 by ATF4 in a CHOP-dependent manner enables the eventual recovery of protein translation. This can contribute to reperfusion injury through increasing the level of ER protein load.

\section{Figure 3. Alzheimer's disease and ER stress}

(A) In health, amyloid precursor protein (APP) is cleaved sequentially by $\beta$ secretase followed by $\gamma$-secretase in the TGN and early endosomes mainly 
generating non-toxic $A \beta_{40}$. APP is recycled via the endosomal pathway. (B) In Alzheimer's disease, toxic $A \beta_{42}$ is generated and secreted. Exogenous $A \beta_{42}$ causes ER stress via a poorly understood mechanism. In some cases of familial Alzheimer's disease, mutations in PS1 impair trafficking of APP, thereby enhancing $A \beta_{42}$ secretion. Mutated PS1 may also lead to APP processing within the ER.

\section{Figure 4: ERAD of amyloid precursor protein}

Newly synthesised proteins, for example amyloid precursor protein (APP), interact with ER chaperones during multiple folding cycles until they reach their native folded state. Overexpression of BiP can increase retention of APP in the ER. If protein folding fails, the terminally misfolded client is targeted for degradation via ERAD. The interaction of glycoprotein substrates with both the folding machinery and the ERAD machinery is governed by cycles of demannosylation and re-mannosylation. Eventually, low mannose species can interact with EDEM and be targeted for dislocation from the ER lumen into the cytosol. This process is incompletely understood and displays substrate specific differences, but for APP involves a complex containing Hrd1 and Sel1L. Once in the cytosol, the ERAD substrate is ubiquitinated and eventually degraded by the proteasome. 
Figure 5: FENIB and the ER overload response

(A) Eosin staining of cerebral cortex from individuals with wild-type neuroserpin (WT) and the S52R or G392E mutations. Mutant protein is retained as polymers within the ER to form Collins bodies (red). The rate of polymer formation correlates with the age at which symptoms develop and the amount of Collins' bodies that can be detected. (B) Monomeric serpins, for example neuroserpin, present a reactive centre loop (red) that functions as a pseudosubstrate for their target protease. However, point mutations in the shutter domain (purple circle) open $\beta$-sheet $A$ (green) to allow the insertion of the reactive centre loop belonging to a second serpin molecule. If allowed to propagate, this loop-sheet linkage generates large stable pathological polymers that are retained in the ER to form Collins' bodies. (C) These polymers are formed of folded neuroserpin and therefore fail to activate the UPR. Instead they cause the release of ER calcium into the cytosol, which causes $\mathrm{NF \kappa B}$ activation and target gene induction. 


\begin{tabular}{|c|c|c|c|c|}
\hline Disease & Neurological phenotype & Cause & $\begin{array}{l}\text { Proposed mechanism for } \\
\text { ER dysfunction }\end{array}$ & $\begin{array}{c}\text { Selected } \\
\text { references }\end{array}$ \\
\hline $\begin{array}{l}\mathrm{CACH} / \mathrm{VWM} \\
\text { leukodystrophy }\end{array}$ & $\begin{array}{l}\text { Cerebellar ataxia } \\
\text { Central hypomyelination } \\
\text { Autosomal recessive }\end{array}$ & elF2B mutations & Enhanced ATF4 synthesis & $22-24$ \\
\hline $\begin{array}{l}\text { Pelizaeus- } \\
\text { Merzbacher } \\
\text { leukodystrophy }\end{array}$ & $\begin{array}{l}\text { Cerebellar ataxia } \\
\text { Central hypomyelination } \\
\text { X-linked }\end{array}$ & PLP1 gene duplication & $\begin{array}{l}\text { Accumulation of PLP1 } \\
\text { within the ER }\end{array}$ & 26 \\
\hline $\begin{array}{l}\text { Charcot-Marie } \\
\text { tooth type } 1 \mathrm{~A}\end{array}$ & $\begin{array}{l}\text { Peripheral sensory neuropathy } \\
\text { Peripheral demyelination } \\
\text { Autosomal dominant }\end{array}$ & $\begin{array}{l}\text { PMP22 mutation or } \\
\text { duplication }\end{array}$ & $\begin{array}{l}\text { Accumulation of myelin } \\
\text { protein PMP22 within the } \\
\text { ER }\end{array}$ & 133 \\
\hline $\begin{array}{l}\text { Charcot-Marie } \\
\text { tooth type 1B }\end{array}$ & $\begin{array}{l}\text { Peripheral sensory neuropathy } \\
\text { Peripheral demyelination } \\
\text { Autosomal dominant }\end{array}$ & MPZ mutation & $\begin{array}{l}\text { Presumed accumulation of } \\
\text { myelin protein PO within } \\
\text { the ER }\end{array}$ & 27 \\
\hline Multiple sclerosis & $\begin{array}{l}\text { Progressive motor and } \\
\text { cognitive impairment } \\
\text { Patchy central demyelination } \\
\text { Sporadic }\end{array}$ & $\begin{array}{l}\text { Inflammatory loss of } \\
\text { myelination }\end{array}$ & $\begin{array}{l}\text { Inflammation-driven } \quad \text { ER } \\
\text { stress }\end{array}$ & 120,121 \\
\hline $\begin{array}{l}\text { Marinesco- } \\
\text { Sjögren syndrome }\end{array}$ & $\begin{array}{l}\text { Cerebellar ataxia } \\
\text { Purkinje cell loss } \\
\text { Autosomal recessive }\end{array}$ & SIL1 gene mutation & $\begin{array}{l}\text { BiP dysfunction due to } \\
\text { impaired SIL1 nucleotide } \\
\text { exchange activity }\end{array}$ & 64,65 \\
\hline Alzheimer disease & $\begin{array}{ll}\text { Loss of cortical } & \begin{array}{l}\text { neurones } \\
\text { cognitive }\end{array} \\
\text { Progressive } & \\
\text { impairment } & \\
\text { Sporadic } & \\
\& & \end{array}$ & $\begin{array}{l}\text { Poorly understood } \\
\beta \text {-amyloid accumulation } \\
\text { hyperphosphorylation of } \\
\text { tau }\end{array}$ & $\begin{array}{l}\text { Impaired ER calcium } \\
\text { homeostasis } \\
\text { Direct } A \beta \text { toxicity }\end{array}$ & $\begin{array}{l}2-4,71-73,75,80, \\
81,83\end{array}$ \\
\hline
\end{tabular}




\begin{tabular}{|c|c|c|c|c|}
\hline & Autosomal dominant & & & \\
\hline $\begin{array}{l}\text { Parkinson } \\
\text { disease }\end{array}$ & $\begin{array}{l}\text { Progressive motor and } \\
\text { cognitive dysfunction } \\
\text { Sporadic } \\
\text { Autosomal Recessive } \\
\text { Autosomal Dominant }\end{array}$ & 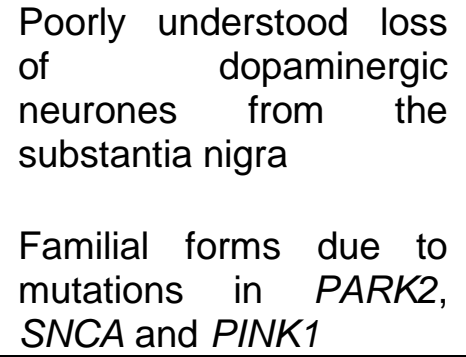 & $\begin{array}{l}\text { Impaired mitochondrial } \\
\text { ATP generation causing } \\
\text { secondary ER failure } \\
\text { ER accumulation of } \\
\text { aggregated synuclein }\end{array}$ & $\begin{array}{l}87,91,93,96,101- \\
104\end{array}$ \\
\hline $\begin{array}{l}\text { Huntington } \\
\text { disease }\end{array}$ & $\begin{array}{l}\text { Progressive motor and } \\
\text { cognitive dysfunction } \\
\text { Autosomal Dominant }\end{array}$ & $\begin{array}{l}\text { Expansion of CAG } \\
\text { repeats in the HTT gene } \\
\text { leading to selective } \\
\text { neuronal loss in caudate } \\
\text { and putamen }\end{array}$ & $\begin{array}{l}\begin{array}{l}\text { Failure of } \\
\text { likely due }\end{array} \text { to cytosolic } \\
\text { aggregates } \\
\text { impairing }\end{array}$ & $12,106-108$ \\
\hline $\begin{array}{l}\text { Amyotrophic } \\
\text { lateral sclerosis }\end{array}$ & $\begin{array}{l}\text { Progressive motor impairment } \\
\text { Sporadic } \\
\& \\
\text { Autosomal Dominant }\end{array}$ & $\begin{array}{l}\text { Poorly understood loss } \\
\text { of motor neurones } \\
\text { Some familiar forms due } \\
\text { to mutations in SOD1 } \\
\text { gene }\end{array}$ & $\begin{array}{l}\text { Accumulation of mutant } \\
\text { SOD1 within the ER }\end{array}$ & $109,111-116,119$ \\
\hline Prion diseases & $\begin{array}{l}\text { Spongiform encephalopathy } \\
\text { Infective } \\
\& \\
\text { Autosomal Dominant }\end{array}$ & $\begin{array}{l}\text { Propagation of infective } \\
\text { prion conformation of } \\
\text { PrP protein }\end{array}$ & $\begin{array}{l}\text { Impaired cellular } \\
\text { proteostasis } \\
\text { Possible direct ER toxicity }\end{array}$ & $5-7,9$ \\
\hline FENIB & $\begin{array}{l}\text { Progressive dementia and } \\
\text { epilepsy } \\
\text { Autosomal Dominant }\end{array}$ & Mutations of SERPINI1 & $\begin{array}{l}\text { Polymerised neuoserpin } \\
\text { accumulates within the ER } \\
\text { activating the ER overload } \\
\text { response }\end{array}$ & 11,124 \\
\hline $\begin{array}{l}\text { Tuberous } \\
\text { sclerosis complex }\end{array}$ & $\begin{array}{l}\text { Central hamartomas cause } \\
\text { epilepsy often with cognitive } \\
\text { and behavioural defects }\end{array}$ & $\begin{array}{l}\text { TSC1 and } \\
\text { mutations }\end{array}$ & $\begin{array}{l}\text { mTORC-mediated } \\
\text { impairment of ER stress } \\
\text { signalling }\end{array}$ & 134 \\
\hline
\end{tabular}




\begin{tabular}{|c|c|c|c|c|}
\hline & Autosomal Dominant & & & \\
\hline Epilepsy & $\begin{array}{l}\text { Progressive neuronal loss } \\
\text { Sporadic }\end{array}$ & Repeated seizure activity & $\begin{array}{l}\text { Incompletely understood } \\
\text { Likely involves disturbed } \\
\text { ER calcium homeostasis } \\
\end{array}$ & 135 \\
\hline $\begin{array}{c}\text { Wolfram } \\
\text { syndrome } 1\end{array}$ & $\begin{array}{l}\text { Diabetes insipidus, optic } \\
\text { atrophy, deafness } \\
\text { Autosomal Recessive }\end{array}$ & $\begin{array}{l}\text { Mutations of WFS1 } \\
\text { gene. }\end{array}$ & $\begin{array}{l}\text { WFS1 encodes an ER ion } \\
\text { channel whose dysfunction } \\
\text { induces ER stress }\end{array}$ & 136 \\
\hline Torsion dystonia 1 & $\begin{array}{l}\text { Involuntary sustained muscle } \\
\text { contraction } \\
\text { Autosomal Dominant }\end{array}$ & $\begin{array}{l}\text { Mutations in TOR1A } \\
\text { gene }\end{array}$ & $\begin{array}{l}\text { Impairment of Torsin A, an } \\
\text { AAA ATPase chaperone in } \\
\text { the ER }\end{array}$ & 137 \\
\hline $\begin{array}{l}\text { Lipid storage } \\
\text { disorders (e.g. } \\
\text { Gaucher disease) }\end{array}$ & $\begin{array}{l}\text { Progressive ataxia, mental } \\
\text { and motor deficiency } \\
\text { Autosomal Recessive }\end{array}$ & Mutations in GBA & $\begin{array}{l}\text { Disturbed ER calcium } \\
\text { homeostasis and } \\
\text { accumulation of mutated } \\
\text { protein within the ER }\end{array}$ & 138 \\
\hline $\begin{array}{l}\text { Cerebral } \\
\text { ischaemia }\end{array}$ & $\begin{array}{l}\text { Neuronal death } \\
\text { Sporadic }\end{array}$ & $\begin{array}{l}\text { Ischaemia causing } \\
\text { impaired protein folding }\end{array}$ & $\begin{array}{l}\text { Energy deficiency causing } \\
\text { ER chaperone and enzyme } \\
\text { dysfunction }\end{array}$ & $1,51,54,59,61,62$ \\
\hline Sleep apnoea & $\begin{array}{l}\text { Neuronal death } \\
\text { Sporadic. }\end{array}$ & $\begin{array}{l}\text { Ischaemia causing } \\
\text { impaired protein folding }\end{array}$ & $\begin{array}{l}\text { Energy deficiency causing } \\
\text { ER chaperone and enzyme } \\
\text { dysfunction }\end{array}$ & 45 \\
\hline Trauma & $\begin{array}{l}\text { Neuronal death } \\
\text { Sporadic }\end{array}$ & $\begin{array}{l}\text { Neuronal trauma and } \\
\text { impaired perfusion }\end{array}$ & $\begin{array}{l}\text { Incompletely understood } \\
\text { Likely involves disturbed } \\
\text { energy metabolism and ER } \\
\text { calcium homeostasis }\end{array}$ & 139 \\
\hline
\end{tabular}




\section{Table1: Neurodegenerative diseases and ER stress: an overview.}

$\mathrm{CACH}$ : Childhood ataxia with central hypomyelination; VWM: vanishing white matter; elF2: eukaryotic translation initiation factor 2; ATF4: activating transcription factor 4; PLP1: proteolipid protein 1; CHOP: CCAAT/enhancer binding protein; IRE1: Inositolrequiring enzyme-1; Bip: Binding immunoglobulin protein; PMP22: peripheral myelin protein 22; PS1: presenilin 1; ERAD: ERassociated protein degradation; SOD1: Cu/Zn superoxide dismutase enzyme; SERCA: sarco/endoplasmic reticulum Ca2+ATPase; PLP1: proteolipid protein 1; MPZ: myelin protein zero 


\section{References}

1. Nakka VP, Gusain A, Raghubir R. Endoplasmic reticulum stress plays critical role in brain damage after cerebral ischemia/reperfusion in rats. Neurotox Res. 2010; 17(2): 189-202.

2. Kaneko M, Koike H, Saito R, Kitamura Y, Okuma Y, Nomura Y. Loss of HRD1-mediated protein degradation causes amyloid precursor protein accumulation and amyloid-beta generation. J Neurosci. 2010; 30(11): 3924-32. 3. Lee JH, Won SM, Suh J, Son SJ, Moon GJ, Park UJ, et al. Induction of the unfolded protein response and cell death pathway in Alzheimer's disease, but not in aged Tg2576 mice. Exp Mol Med. 2010; 42(5): 386-94.

4. Honjo Y, Ito H, Horibe T, Takahashi R, Kawakami K. Protein disulfide isomerase-immunopositive inclusions in patients with Alzheimer disease. Brain Res. 2010; 1349: 90-6.

5. Quaglio E, Restelli E, Garofoli A, Dossena S, De Luigi A, Tagliavacca L, et al. Expression of mutant or cytosolic PrP in transgenic mice and cells is not associated with endoplasmic reticulum stress or proteasome dysfunction. PLoS ONE. $2011 ;$ 6(4): e19339.

6. Dossena S, Imeri L, Mangieri M, Garofoli A, Ferrari L, Senatore A, et al. Mutant prion protein expression causes motor and memory deficits and abnormal sleep patterns in a transgenic mouse model. Neuron. 2008; 60(4): 598-609.

7. Nunziante M, Ackermann K, Dietrich K, Wolf H, Gadtke L, Gilch S, et al. Proteasomal dysfunction and endoplasmic reticulum stress enhance trafficking of 
prion protein aggregates through the secretory pathway and increase accumulation of pathologic prion protein. J Biol Chem. 2011; 286(39): 33942-53. 8. Rane NS, Kang SW, Chakrabarti O, Feigenbaum L, Hegde RS. Reduced translocation of nascent prion protein during ER stress contributes to neurodegeneration. Dev Cell. 2008; 15(3): 359-70.

9. Moreno JA, Radford H, Peretti D, Steinert JR, Verity N, Martin MG, et al. Sustained translational repression by elF2alpha-P mediates prion neurodegeneration. Nature. 2012; 485(7399): 507-11.

10. Marciniak SJ, Ron D. Endoplasmic reticulum stress signaling in disease. Physiol Rev. 2006; 86(4): 1133-49.

11. Davies MJ, Miranda E, Roussel BD, Kaufman RJ, Marciniak SJ, Lomas DA. Neuroserpin polymers activate NF-kappaB by a calcium signalling pathway that is independent of the unfolded protein response. J Biol Chem. 2009; 284(27): 18202-9.

12. Duennwald ML, Lindquist S. Impaired ERAD and ER stress are early and specific events in polyglutamine toxicity. Genes Dev. 2008; 22(23): 3308-19.

13. Marciniak SJ, Yun CY, Oyadomari S, Novoa I, Zhang Y, Jungreis R, et al. $\mathrm{CHOP}$ induces death by promoting protein synthesis and oxidation in the stressed endoplasmic reticulum. Genes Dev. 2004; 18: 3066-77.

14. Harding $\mathrm{H}$, Zhang $\mathrm{Y}$, Ron D. Translation and protein folding are coupled by an endoplasmic reticulum resident kinase. Nature. 1999; 397(6716): 271-4.

15. Owen CR, Kumar R, Zhang P, McGrath BC, Cavener DR, Krause GS. PERK is responsible for the increased phosphorylation of elF2alpha and the 
severe inhibition of protein synthesis after transient global brain ischemia. $\mathrm{J}$ Neurochem. 2005; 94(5): 1235-42.

16. Marciniak SJ, Garcia-Bonilla L, Hu J, Harding HP, Ron D. Activationdependent substrate recruitment by the eukaryotic translation initiation factor 2 kinase PERK. J Cell Biol. 2006; 172(2): 201-9.

17. Harding $\mathrm{H}$, Zhang $\mathrm{Y}$, Zeng $\mathrm{H}$, Novoa I, Lu $\mathrm{P}$, Calfon $\mathrm{M}$, et al. An integrated stress response regulates amino acid metabolism and resistance to oxidative stress. Mol Cell. 2003; 11: 619-33.

18. Dalton LE, Healey E, Irving J, Marciniak SJ. Phosphoproteins in stressinduced disease. Prog Mol Biol TransI Sci. 2012; 106: 189-221.

19. Harding HP, Zhang Y, Zeng H, Novoa I, Lu PD, Calfon M, et al. An integrated stress response regulates amino acid metabolism and resistance to oxidative stress. Mol Cell. 2003; 11(3): 619-33.

20. Hao S, Sharp JW, Ross-Inta CM, McDaniel BJ, Anthony TG, Wek RC, et al. Uncharged tRNA and sensing of amino acid deficiency in mammalian piriform cortex. Science. 2005; 307(5716): 1776-8.

21. Maurin AC, Jousse C, Averous J, Parry L, Bruhat A, Cherasse Y, et al. The GCN2 kinase biases feeding behavior to maintain amino acid homeostasis in omnivores. Cell Metab. 2005; 1(4): 273-7.

22. Kantor L, Harding HP, Ron D, Schiffmann R, Kaneski CR, Kimball SR, et al. Heightened stress response in primary fibroblasts expressing mutant elF2B genes from $\mathrm{CACH} / \mathrm{VWM}$ leukodystrophy patients. Hum Genet. 2005; 118(1): 99 106. 
23. Leegwater PA, Vermeulen G, Konst AA, Naidu S, Mulders J, Visser A, et al. Subunits of the translation initiation factor elF2B are mutant in leukoencephalopathy with vanishing white matter. Nat Genet. 2001; 29(4): 383-8. 24. Richardson JP, Mohammad SS, Pavitt GD. Mutations causing childhood ataxia with central nervous system hypomyelination reduce eukaryotic initiation factor 2B complex formation and activity. Mol Cell Biol. 2004; 24(6): 2352-63. 25. Harding HP, Calfon M, Urano F, Novoa I, Ron D. Transcriptional and translational control in the mammalian unfolded protein response. Annu Rev Cell Dev Biol. 2002; 18: 575-99.

26. Southwood CM, Garbern J, Jiang W, Gow A. The unfolded protein response modulates disease severity in Pelizaeus-Mezbacher Disease. Neuron. 2002; 36: 585-96.

27. Pennuto M, Tinelli E, Malaguti M, Del Carro U, D'Antonio M, Ron D, et al. Ablation of the UPR-mediator CHOP restores motor function and reduces demyelination in Charcot-Marie-Tooth 1B mice. Neuron. 2008; 57(3): 393-405.

28. Boyce M, Bryant KF, Jousse C, Long K, Harding HP, Scheuner D, et al. A Selective inhibitor of elF2a dephosphorylation protects cells from ER stress. Science. 2005; 307: 935-9.

29. Tsaytler P, Harding HP, Ron D, Bertolotti A. Selective inhibition of a regulatory subunit of protein phosphatase 1 restores proteostasis. Science. 2011; 332(6025): 91-4. 
30. Kondo S, Murakami T, Tatsumi K, Ogata M, Kanemoto S, Otori K, et al. OASIS, a CREB/ATF-family member, modulates UPR signalling in astrocytes. Nat Cell Biol. 2005; 7(2): 186-94.

31. Calfon M, Zeng H, Urano F, Till JH, Hubbard SR, Harding HP, et al. IRE1 couples endoplasmic reticulum load to secretory capacity by processing the XBP-1 mRNA. Nature. 2002; 415: 92-6.

32. Hosoi T, Ogawa K, Ozawa K. Homocysteine induces X-box-binding protein 1 splicing in the mice brain. Neurochem Int. 2010; 56(2): 216-20.

33. Meusser B, Hirsch C, Jarosch E, Sommer T. ERAD: the long road to destruction. Nat Cell Biol. 2005; 7(8): 766-72.

34. Haynes CM, Titus EA, Cooper AA. Degradation of misfolded proteins prevents ER-derived oxidative stress and cell death. Mol Cell. 2004; 15(5): 76776.

35. Yoshida H, Matsui T, Hosokawa N, Kaufman RJ, Nagata K, Mori K. A time-dependent phase shift in the Mammalian unfolded protein response. Dev Cell. 2003; 4(2): 265-71.

36. Rissanen A, Sivenius J, Jolkkonen J. Prolonged bihemispheric alterations in unfolded protein response related gene expression after experimental stroke. Brain Res. 2006; 1087(1): 60-6.

37. Morimoto N, Oida Y, Shimazawa M, Miura M, Kudo T, Imaizumi K, et al. Involvement of endoplasmic reticulum stress after middle cerebral artery occlusion in mice. Neuroscience. 2007; 147(4): 957-67. 
38. Hayashi T, Hamakawa K, Nagotani S, Jin G, Li F, Deguchi K, et al. HMG CoA reductase inhibitors reduce ischemic brain injury of Wistar rats through decreasing oxidative stress on neurons. Brain Res. 2005; 1037(1-2): 52-8. 39. Szydlowska K, Tymianski M. Calcium, ischemia and excitotoxicity. Cell Calcium. 2010; 47(2): 122-9.

40. Coe H, Michalak M. Calcium binding chaperones of the endoplasmic reticulum. Gen Physiol Biophys. 2009; 28 Spec No Focus: F96-F103.

41. Nguyen HN, Wang C, Perry DC. Depletion of intracellular calcium stores is toxic to SH-SY5Y neuronal cells. Brain Res. 2002; 924(2): 159-66.

42. Zhang F, Liu CL, Hu BR. Irreversible aggregation of protein synthesis machinery after focal brain ischemia. J Neurochem. 2006; 98(1): 102-12.

43. Althausen S, Mengesdorf T, Mies G, Olah L, Nairn AC, Proud CG, et al. Changes in the phosphorylation of initiation factor elF-2alpha, elongation factor eEF-2 and p70 S6 kinase after transient focal cerebral ischaemia in mice. J Neurochem. 2001; 78(4): 779-87.

44. Qi X, Okuma Y, Hosoi T, Nomura Y. Edaravone protects against hypoxia/ischemia-induced endoplasmic reticulum dysfunction. J Pharmacol Exp Ther. 2004; 311(1): 388-93.

45. Zhu Y, Fenik P, Zhan G, Sanfillipo-Cohn B, Naidoo N, Veasey SC. Eif-2a protects brainstem motoneurons in a murine model of sleep apnea. J Neurosci. 2008; 28(9): 2168-78. 
46. Shibata M, Hattori H, Sasaki T, Gotoh J, Hamada J, Fukuuchi Y.

Activation of caspase-12 by endoplasmic reticulum stress induced by transient middle cerebral artery occlusion in mice. Neuroscience. 2003; 118(2): 491-9.

47. Xue Y, Daly A, Yngvadottir B, Liu M, Coop G, Kim Y, et al. Spread of an inactive form of caspase-12 in humans is due to recent positive selection. Am J Hum Genet. 2006; 78(4): 659-70.

48. Hitomi J, Katayama T, Eguchi Y, Kudo T, Taniguchi M, Koyama Y, et al. Involvement of caspase-4 in endoplasmic reticulum stress-induced apoptosis and Abeta-induced cell death. J Cell Biol. 2004; 165(3): 347-56.

49. Kumar R, Krause GS, Yoshida H, Mori K, DeGracia DJ. Dysfunction of the unfolded protein response during global brain ischemia and reperfusion. J Cereb Blood Flow Metab. 2003; 23(4): 462-71.

50. Chihara K, Saito A, Murakami T, Hino S, Aoki Y, Sekiya H, et al. Increased vulnerability of hippocampal pyramidal neurons to the toxicity of kainic acid in OASIS-deficient mice. J Neurochem. 2009; 110(3): 956-65.

51. Osada N, Kosuge Y, Kihara T, Ishige K, Ito Y. Apolipoprotein E-deficient mice are more vulnerable to ER stress after transient forebrain ischemia. Neurochem Int. 2009; 54(7): 403-9.

52. Tajiri S, Oyadomari S, Yano S, Morioka M, Gotoh T, Hamada JI, et al. Ischemia-induced neuronal cell death is mediated by the endoplasmic reticulum stress pathway involving CHOP. Cell Death Differ. 2004; 11(4): 403-15.

53. Hayashi T, Saito A, Okuno S, Ferrand-Drake M, Dodd RL, Chan PH. Damage to the endoplasmic reticulum and activation of apoptotic machinery by 
oxidative stress in ischemic neurons. J Cereb Blood Flow Metab. 2005; 25(1): 41-53.

54. Oida Y, Shimazawa M, Imaizumi K, Hara H. Involvement of endoplasmic reticulum stress in the neuronal death induced by transient forebrain ischemia in gerbil. Neuroscience. 2008; 151(1): 111-9.

55. Benavides A, Pastor D, Santos P, Tranque P, Calvo S. CHOP plays a pivotal role in the astrocyte death induced by oxygen and glucose deprivation. Glia. 2005; 52(4): 261-75.

56. Paschen W, Hayashi T, Saito A, Chan PH. GADD34 protein levels increase after transient ischemia in the cortex but not in the CA1 subfield: implications for post-ischemic recovery of protein synthesis in ischemia-resistant cells. J Neurochem. 2004; 90(3): 694-701.

57. McCaig D, Imai H, Gallagher L, Graham DI, Harland J, Moira Brown S, et al. Evolution of GADD34 expression after focal cerebral ischaemia. Brain Res. 2005; 1034(1-2): 51-61.

58. Sokka AL, Putkonen N, Mudo G, Pryazhnikov E, Reijonen S, Khiroug L, et al. Endoplasmic reticulum stress inhibition protects against excitotoxic neuronal injury in the rat brain. J Neurosci. 2007; 27(4): 901-8.

59. Osada N, Kosuge Y, Ishige K, Ito Y. Characterization of neuronal and astroglial responses to ER stress in the hippocampal CA1 area in mice following transient forebrain ischemia. Neurochem Int. 2010; 57(1): 1-7.

60. Yu Z, Luo H, Fu W, Mattson MP. The endoplasmic reticulum stressresponsive protein GRP78 protects neurons against excitotoxicity and apoptosis: 
suppression of oxidative stress and stabilization of calcium homeostasis. Exp Neurol. 1999; 155(2): 302-14.

61. Ouyang YB, Xu LJ, Emery JF, Lee AS, Giffard RG. Overexpressing GRP78 influences $\mathrm{Ca} 2+$ handling and function of mitochondria in astrocytes after ischemia-like stress. Mitochondrion. 2011; 11(2): 279-86.

62. Kudo T, Kanemoto S, Hara H, Morimoto N, Morihara T, Kimura R, et al. A molecular chaperone inducer protects neurons from ER stress. Cell Death Differ. 2008; 15(2): 364-75.

63. Tamatani M, Matsuyama T, Yamaguchi A, Mitsuda N, Tsukamoto Y, Taniguchi M, et al. ORP150 protects against hypoxia/ischemia-induced neuronal death. Nature medicine. 2001; 7(3): 317-23.

64. Zhao L, Longo-Guess C, Harris BS, Lee JW, Ackerman SL. Protein accumulation and neurodegeneration in the woozy mutant mouse is caused by disruption of SIL1, a cochaperone of BiP. Nat Genet. 2005; 37(9): 974-9.

65. Zhao L, Rosales C, Seburn K, Ron D, Ackerman SL. Alteration of the unfolded protein response modifies neurodegeneration in a mouse model of Marinesco-Sjogren syndrome. Hum Mol Genet. 2010; 19(1): 25-35.

66. Luheshi LM, Tartaglia GG, Brorsson AC, Pawar AP, Watson IE, Chiti F, et al. Systematic in vivo analysis of the intrinsic determinants of amyloid Beta pathogenicity. PLoS Biol. 2007; 5(11): e290.

67. Katayama T, Imaizumi K, Sato N, Miyoshi K, Kudo T, Hitomi J, et al. Presenilin-1 mutations downregulate the signalling pathway of the unfoldedprotein response. Nat Cell Biol. 1999; 1(8): 479-85. 
68. Hoozemans JJ, Veerhuis R, Van Haastert ES, Rozemuller JM, Baas F, Eikelenboom $\mathrm{P}$, et al. The unfolded protein response is activated in Alzheimer's disease. Acta Neuropathol. 2005; 110(2): 165-72.

69. Hoozemans JJ, Stieler J, van Haastert ES, Veerhuis R, Rozemuller AJ, Baas $F$, et al. The unfolded protein response affects neuronal cell cycle protein expression: implications for Alzheimer's disease pathogenesis. Exp Gerontol. 2006; 41(4): 380-6.

70. Unterberger U, Hoftberger R, Gelpi E, Flicker H, Budka H, Voigtlander T. Endoplasmic reticulum stress features are prominent in Alzheimer disease but not in prion diseases in vivo. J Neuropathol Exp Neurol. 2006; 65(4): 348-57. 71. Hoozemans JJ, van Haastert ES, Nijholt DA, Rozemuller AJ, Eikelenboom $\mathrm{P}$, Scheper $\mathrm{W}$. The unfolded protein response is activated in pretangle neurons in Alzheimer's disease hippocampus. Am J Pathol. 2009; 174(4): 1241-51. 72. Resende R, Ferreiro E, Pereira C, Oliveira CR. ER stress is involved in Abeta-induced GSK-3beta activation and tau phosphorylation. J Neurosci Res. 2008; 86(9): 2091-9.

73. Lee do Y, Lee KS, Lee HJ, Kim do H, Noh YH, Yu K, et al. Activation of PERK signaling attenuates Abeta-mediated ER stress. PLoS ONE. 2010; 5(5): e10489.

74. Seyb KI, Ansar S, Bean J, Michaelis ML. beta-Amyloid and endoplasmic reticulum stress responses in primary neurons: effects of drugs that interact with the cytoskeleton. J Mol Neurosci. 2006; 28(2): 111-23. 
75. Song S, Lee H, Kam TI, Tai ML, Lee JY, Noh JY, et al. E2-25K/Hip-2 regulates caspase-12 in ER stress-mediated Abeta neurotoxicity. J Cell Biol. 2008; 182(4): 675-84.

76. Ghribi O, Herman MM, DeWitt DA, Forbes MS, Savory J. Abeta(1-42) and aluminum induce stress in the endoplasmic reticulum in rabbit hippocampus, involving nuclear translocation of gadd 153 and NF-kappaB. Brain Res Mol Brain Res. 2001; 96(1-2): 30-8.

77. Schapansky J, Olson K, Van Der Ploeg R, Glazner G. NF-kappaB activated by ER calcium release inhibits Abeta-mediated expression of $\mathrm{CHOP}$ protein: enhancement by AD-linked mutant presenilin 1. Exp Neurol. 2007; 208(2): 169-76.

78. Casas-Tinto S, Zhang Y, Sanchez-Garcia J, Gomez-Velazquez M, Rincon-Limas DE, Fernandez-Funez P. The ER stress factor XBP1s prevents amyloid-beta neurotoxicity. Hum Mol Genet. 2011; 20(11): 2144-60.

79. Milhavet O, Martindale JL, Camandola S, Chan SL, Gary DS, Cheng A, et al. Involvement of Gadd153 in the pathogenic action of presenilin-1 mutations. J Neurochem. 2002; 83(3): 673-81.

80. Jin H, Sanjo N, Uchihara T, Watabe K, St George-Hyslop P, Fraser PE, et al. Presenilin-1 holoprotein is an interacting partner of sarco endoplasmic reticulum calcium-ATPase and confers resistance to endoplasmic reticulum stress. J Alzheimers Dis. 2010; 20(1): 261-73.

81. Stutzmann GE, Mattson MP. Endoplasmic reticulum $\mathrm{Ca}(2+)$ handling in excitable cells in health and disease. Pharmacol Rev. 2011; 63(3): 700-27. 
82. Bezprozvanny I, Mattson MP. Neuronal calcium mishandling and the pathogenesis of Alzheimer's disease. Trends Neurosci. 2008; 31(9): 454-63.

83. O'Connor T, Sadleir KR, Maus E, Velliquette RA, Zhao J, Cole SL, et al. Phosphorylation of the translation initiation factor elF2alpha increases BACE1 levels and promotes amyloidogenesis. Neuron. 2008; 60(6): 988-1009.

84. Kudo T, Okumura M, Imaizumi K, Araki W, Morihara T, Tanimukai H, et al. Altered localization of amyloid precursor protein under endoplasmic reticulum stress. Biochem Biophys Res Commun. 2006; 344(2): 525-30.

85. Saltini G, Dominici R, Lovati C, Cattaneo M, Michelini S, Malferrari G, et al. A novel polymorphism in SEL1L confers susceptibility to Alzheimer's disease. Neurosci Lett. 2006; 398(1-2): 53-8.

86. Bauereis B, Haskins WE, Lebaron RG, Renthal R. Proteomic insights into the protective mechanisms of an in vitro oxidative stress model of early stage Parkinson's disease. Neurosci Lett. 2011; 488(1): 11-6.

87. Sado M, Yamasaki Y, Iwanaga T, Onaka Y, Ibuki T, Nishihara S, et al. Protective effect against Parkinson's disease-related insults through the activation of XBP1. Brain Res. 2009; 1257: 16-24.

88. Egawa N, Yamamoto K, Inoue H, Hikawa R, Nishi K, Mori K, et al. The endoplasmic reticulum stress sensor, ATF6alpha, protects against neurotoxininduced dopaminergic neuronal death. J Biol Chem. 2011; 286(10): 7947-57. 89. Chigurupati S, Wei Z, Belal C, Vandermey M, Kyriazis GA, Arumugam TV, et al. The homocysteine-inducible endoplasmic reticulum stress protein counteracts calcium store depletion and induction of CCAAT enhancer-binding 
protein homologous protein in a neurotoxin model of Parkinson disease. J Biol Chem. 2009; 284(27): 18323-33.

90. Silva RM, Ries V, Oo TF, Yarygina O, Jackson-Lewis V, Ryu EJ, et al. CHOP/GADD153 is a mediator of apoptotic death in substantia nigra dopamine neurons in an in vivo neurotoxin model of parkinsonism. J Neurochem. 2005; 95(4): 974-86.

91. Dukes AA, Van Laar VS, Cascio M, Hastings TG. Changes in endoplasmic reticulum stress proteins and aldolase $A$ in cells exposed to dopamine. J Neurochem. 2008; 106(1): 333-46.

92. Hoozemans JJ, van Haastert ES, Eikelenboom P, de Vos RA, Rozemuller JM, Scheper W. Activation of the unfolded protein response in Parkinson's disease. Biochem Biophys Res Commun. 2007; 354(3): 707-11.

93. Silva RM, Ries V, Oo TF, Yarygina O, Jackson-Lewis V, Ryu EJ, et al. CHOP/GADD153 is a mediator of apoptotic death in substantia nigra dopamine neurons in an in vivo neurotoxin model of parkinsonism. J Neurochem. 2005; 95(4): 974-86.

94. Kitada T, Asakawa S, Hattori N, Matsumine H, Yamamura Y, Minoshima $\mathrm{S}$, et al. Mutations in the parkin gene cause autosomal recessive juvenile parkinsonism. Nature. 1998; 392(6676): 605-8.

95. Shimura H, Hattori N, Kubo S, Mizuno Y, Asakawa S, Minoshima S, et al. Familial Parkinson disease gene product, parkin, is a ubiquitin-protein ligase. Nat Genet. 2000; 25(3): 302-5. 
96. Bouman L, Schlierf A, Lutz AK, Shan J, Deinlein A, Kast J, et al. Parkin is transcriptionally regulated by ATF4: evidence for an interconnection between mitochondrial stress and ER stress. Cell Death Differ. 2011; 18(5): 769-82.

97. Narendra D, Tanaka A, Suen DF, Youle RJ. Parkin is recruited selectively to impaired mitochondria and promotes their autophagy. J Cell Biol. 2008; 183(5): 795-803.

98. Shimura H, Schlossmacher MG, Hattori N, Frosch MP, Trockenbacher A, Schneider R, et al. Ubiquitination of a New Form of a-Synuclein by Parkin from Human Brain: Implications for Parkinson's Disease. Science. 2001; 28: 28.

99. Kruger R, Kuhn W, Muller T, Woitalla D, Graeber M, Kosel S, et al. Ala30Pro mutation in the gene encoding alpha-synuclein in Parkinson's disease. Nat Genet. 1998; 18(2): 106-8.

100. Smith WW, Jiang H, Pei Z, Tanaka $\mathrm{Y}$, Morita $\mathrm{H}$, Sawa A, et al. Endoplasmic reticulum stress and mitochondrial cell death pathways mediate A53T mutant alpha-synuclein-induced toxicity. Hum Mol Genet. 2005; 14(24): $3801-11$.

101. Bellucci A, Navarria L, Zaltieri M, Falarti E, Bodei S, Sigala S, et al. Induction of the unfolded protein response by alpha-synuclein in experimental models of Parkinson's disease. J Neurochem. 2011; 116(4): 588-605. 102. Colla E, Coune P, Liu Y, Pletnikova O, Troncoso JC, Iwatsubo T, et al. Endoplasmic reticulum stress is important for the manifestations of alphasynucleinopathy in vivo. J Neurosci. 2012; 32(10): 3306-20. 
103. Inden M, Kitamura $\mathrm{Y}$, Takeuchi $\mathrm{H}$, Yanagida $\mathrm{T}$, Takata K, Kobayashi $\mathrm{Y}$, et al. Neurodegeneration of mouse nigrostriatal dopaminergic system induced by repeated oral administration of rotenone is prevented by 4-phenylbutyrate, a chemical chaperone. J Neurochem. 2007; 101(6): 1491-504.

104. Hara H, Kamiya T, Adachi T. Endoplasmic reticulum stress inducers provide protection against 6-hydroxydopamine-induced cytotoxicity. Neurochem Int. $2011 ;$ 58(1): 35-43.

105. Carnemolla A, Fossale E, Agostoni E, Michelazzi S, Calligaris R, De Maso L, et al. Rrs1 is involved in endoplasmic reticulum stress response in Huntington disease. J Biol Chem. 2009; 284(27): 18167-73.

106. Lajoie P, Snapp EL. Changes in BiP availability reveal hypersensitivity to acute endoplasmic reticulum stress in cells expressing mutant huntingtin. J Cell Sci. 2011; 124(Pt 19): 3332-43.

107. Bennett EJ, Shaler TA, Woodman B, Ryu KY, Zaitseva TS, Becker CH, et al. Global changes to the ubiquitin system in Huntington's disease. Nature. 2007; 448(7154): 704-8.

108. Higo T, Hamada K, Hisatsune C, Nukina N, Hashikawa T, Hattori M, et al. Mechanism of ER stress-induced brain damage by IP(3) receptor. Neuron. 2010; 68(5): 865-78.

109. Sasaki S. Endoplasmic reticulum stress in motor neurons of the spinal cord in sporadic amyotrophic lateral sclerosis. J Neuropathol Exp Neurol. 2010; 69(4): 346-55. 
110. Urushitani M, Sik A, Sakurai T, Nukina N, Takahashi R, Julien JP. Chromogranin-mediated secretion of mutant superoxide dismutase proteins linked to amyotrophic lateral sclerosis. Nat Neurosci. 2006; 9(1): 108-18.

111. Kikuchi H, Almer G, Yamashita S, Guegan C, Nagai M, Xu Z, et al. Spinal cord endoplasmic reticulum stress associated with a microsomal accumulation of mutant superoxide dismutase-1 in an ALS model. Proc Natl Acad Sci U S A. 2006; 103(15): 6025-30.

112. Kieran D, Woods I, Villunger A, Strasser A, Prehn JH. Deletion of the BH3-only protein puma protects motoneurons from ER stress-induced apoptosis and delays motoneuron loss in ALS mice. Proc Natl Acad Sci U S A. 2007; 104(51): 20606-11.

113. Walker AK, Farg MA, Bye CR, McLean CA, Horne MK, Atkin JD. Protein disulphide isomerase protects against protein aggregation and is S-nitrosylated in amyotrophic lateral sclerosis. Brain. 2010; 133(Pt 1): 105-16.

114. Nagata $\mathrm{T}$, llieva $\mathrm{H}$, Murakami $\mathrm{T}$, Shiote $\mathrm{M}$, Narai $\mathrm{H}$, Ohta $\mathrm{Y}$, et al. Increased ER stress during motor neuron degeneration in a transgenic mouse model of amyotrophic lateral sclerosis. Neurol Res. 2007; 29(8): 767-71.

115. Saxena S, Cabuy E, Caroni P. A role for motoneuron subtype-selective ER stress in disease manifestations of FALS mice. Nat Neurosci. 2009; 12(5): 627-36.

116. Wang L, Popko B, Roos RP. The unfolded protein response in familial amyotrophic lateral sclerosis. Hum Mol Genet. 2011; 20(5): 1008-15. 
117. Hetz C, Thielen P, Matus S, Nassif M, Court F, Kiffin R, et al. XBP-1 deficiency in the nervous system protects against amyotrophic lateral sclerosis by increasing autophagy. Genes Dev. 2009; 23(19): 2294-306.

118. Mori A, Yamashita S, Uchino K, Suga T, Ikeda T, Takamatsu K, et al. Derlin-1 overexpression ameliorates mutant SOD1-induced endoplasmic reticulum stress by reducing mutant SOD1 accumulation. Neurochem Int. 2011; 58(3): 344-53.

119. Nishitoh $\mathrm{H}$, Kadowaki $\mathrm{H}$, Nagai A, Maruyama T, Yokota T, Fukutomi H, et al. ALS-linked mutant SOD1 induces ER stress- and ASK1-dependent motor neuron death by targeting Derlin-1. Genes Dev. 2008; 22(11): 1451-64. 120. Lin W, Bailey SL, Ho H, Harding HP, Ron D, Miller SD, et al. The integrated stress response prevents demyelination by protecting oligodendrocytes against immune-mediated damage. J Clin Invest. 2007; 117(2): 448-56.

121. Lin W, Kemper A, Dupree JL, Harding HP, Ron D, Popko B. Interferongamma inhibits central nervous system remyelination through a process modulated by endoplasmic reticulum stress. Brain. 2006; 129(Pt 5): 1306-18. 122. Davis RL, Shrimpton AE, Holohan PD, Bradshaw C, Feiglin D, Collins GH, et al. Familial dementia caused by polymerization of mutant neuroserpin. Nature. 1999; 401(6751): 376-9.

123. Miranda E, MacLeod I, Davies MJ, Perez J, Romisch K, Crowther DC, et al. The intracellular accumulation of polymeric neuroserpin explains the severity of the dementia FENIB. Hum Mol Genet. 2008; 17(11): 1527-39. 
124. Kroeger H, Miranda E, MacLeod I, Perez J, Crowther DC, Marciniak SJ, et al. Endoplasmic reticulum-associated degradation (ERAD) and autophagy cooperate to degrade polymerogenic mutant serpins. J Biol Chem. 2009; 284(34): 22793-802.

125. Pahl HL, Baeuerle PA. The ER-overload response: activation of NF-kappa B. Trends Biochem Sci. 1997; 22(2): 63-7.

126. Hidvegi T, Ewing M, Hale P, Dippold C, Beckett C, Kemp C, et al. An autophagy-enhancing drug promotes degradation of mutant alpha1-antitrypsin Z and reduces hepatic fibrosis. Science. 2010; 329(5988): 229-32.

127. Chen X, Wu J, Lvovskaya S, Herndon E, Supnet C, Bezprozvanny I. Dantrolene is neuroprotective in Huntington's disease transgenic mouse model. Mol Neurodegener. 2011; 6: 81.

128. Li F, Hayashi T, Jin G, Deguchi K, Nagotani S, Nagano I, et al. The protective effect of dantrolene on ischemic neuronal cell death is associated with reduced expression of endoplasmic reticulum stress markers. Brain Res. 2005; 1048(1-2): 59-68.

129. Jiang P, Gan M, Ebrahim AS, Lin WL, Melrose HL, Yen SH. ER stress response plays an important role in aggregation of alpha-synuclein. Mol Neurodegener. 2010; 5: 56.

130. Reijonen S, Putkonen N, Norremolle A, Lindholm D, Korhonen L. Inhibition of endoplasmic reticulum stress counteracts neuronal cell death and protein aggregation caused by N-terminal mutant huntingtin proteins. Exp Cell Res. 2008; 314(5): 950-60. 
131. Yamamoto K, Tashiro E, Imoto M. Quinotrierixin inhibited ER stressinduced XBP1 mRNA splicing through inhibition of protein synthesis. Biosci Biotechnol Biochem. 2011; 75(2): 284-8.

132. Cross BC, Bond PJ, Sadowski PG, Jha BK, Zak J, Goodman JM, et al. The molecular basis for selective inhibition of unconventional mRNA splicing by an IRE1-binding small molecule. Proc Natl Acad Sci U S A. 2012; 109(15): E86978.

133. D'Urso D, Prior R, Greiner-Petter R, Gabreels-Festen AA, Muller HW. Overloaded endoplasmic reticulum-Golgi compartments, a possible pathomechanism of peripheral neuropathies caused by mutations of the peripheral myelin protein PMP22. J Neurosci. 1998; 18(2): 731-40.

134. Kang YJ, Lu MK, Guan KL. The TSC1 and TSC2 tumor suppressors are required for proper ER stress response and protect cells from ER stress-induced apoptosis. Cell Death Differ. 2011; 18(1): 133-44.

135. Liu G, Guo H, Guo C, Zhao S, Gong D, Zhao Y. Involvement of IRE1alpha signaling in the hippocampus in patients with mesial temporal lobe epilepsy. Brain Res Bull. 2011; 84(1): 94-102.

136. Fonseca SG, Ishigaki S, Oslowski CM, Lu S, Lipson KL, Ghosh R, et al. Wolfram syndrome 1 gene negatively regulates ER stress signaling in rodent and human cells. J Clin Invest. 2010; 120(3): 744-55.

137. Chen P, Burdette AJ, Porter JC, Ricketts JC, Fox SA, Nery FC, et al. The early-onset torsion dystonia-associated protein, torsinA, is a homeostatic 
regulator of endoplasmic reticulum stress response. Hum Mol Genet. 2010; 19(18): 3502-15.

138. Wang F, Agnello G, Sotolongo N, Segatori L. Ca2+ homeostasis modulation enhances the amenability of L444P glucosylcerebrosidase to proteostasis regulation in patient-derived fibroblasts. ACS Chem Biol. 2011; 6(2): $158-68$.

139. Penas C, Verdu E, Asensio-Pinilla E, Guzman-Lenis MS, HerrandoGrabulosa M, Navarro X, et al. Valproate reduces CHOP levels and preserves oligodendrocytes and axons after spinal cord injury. Neuroscience. 2011; 178: 33-44. 


\title{
IMPLICATIONS OF ENDOPLASMIC RETICULUM DYSFUNCTION IN NEUROLOGICAL DISEASE
}

\author{
Benoit D. Roussel ${ }^{1,4} \mathrm{PhD}$, Antonina J. Kruppa ${ }^{1} \mathrm{PhD}$, Elena Miranda ${ }^{2} \mathrm{PhD}$, \\ Damian C. Crowther ${ }^{3} \mathrm{PhD}$, David A. Lomas ${ }^{1} \mathrm{PhD}$ and Stefan J. Marciniak ${ }^{1} \mathrm{PhD}$
}

${ }^{1}$ Department of Medicine, University of Cambridge, Cambridge Institute for Medical Research (CIMR), Wellcome Trust/MRC Building, Hills Road, Cambridge CB2 0XY, UK

2Department of Biology and Biotechnology 'Charles Darwin' and Pasteur Institute-Cenci Bolognetti Foundation, University of Rome 'La Sapienza', piazzale Aldo Moro 5, 00185 Rome, Italy

${ }^{3}$ Department of Genetics, University of Cambridge, Downing Site, Cambridge, CB2 3EH, UK

${ }^{4}$ INSERM U919, University Caen Basse Normandie, Serine Proteases and Pathophysiology of the Neurovascular Unit, Public Interest Group CYCERON, F-14074 Caen, France ( ${ }^{*}$ actual address)

Correspondence should be addressed to:

Dr Benoit D Roussel \& Dr Stefan J Marciniak

Cambridge Institute for Medical Research, Wellcome Trust/MRC Building,

Hills Road, Cambridge CB2 OXY, United Kingdom

Email: broussel@cyceron.fr, sim20@cam.ac.uk 
Key words: ER stress, Neurodegeneration, Cerebral ischaemia, Alzheimer's disease, Parkinson's disease, FENIB

Running title: ER dysfunction in the CNS

Word count: 5,988 (excluding references and legends) 


\section{ABSTRACT}

Endoplasmic reticulum (ER) dysfunction is important in the pathogenesis of many neurological diseases. In this review, we examine the evidence for ER dysfunction in a range of neurological conditions including cerebral ischaemia, sleep apnoea, Alzheimer's disease, multiple sclerosis, amyotrophic lateral sclerosis, the prion diseases and Familial Encephalopathy with Neuroserpin Inclusion Bodies (FENIB). Protein misfolding in the endoplasmic reticulum initiates a well-studied 'Unfolded Protein Response' in energy-starved neurones during stroke that is relevant to the toxicity of reperfusion. The toxic peptide $A \beta$ induces 'ER stress' in Alzheimer's disease leading to activation of similar pathways, while the accumulation of polymeric neuroserpin in the neuronal ER triggers a poorly understood 'ER overload response'. In other neurological disorders such as Parkinson's and Huntington's diseases ER dysfunction is well recognised but the mechanisms for this are less clear. By targeting components of these signalling responses, it may prove possible to ameliorate their toxic effects and treat a range of neurodegenerative conditions.

Word count: 157 


\section{Introduction}

It can be argued that most neurodegenerative disorders arise from defective protein folding. This is clearly true for those rare disorders caused by the misfolding of mutated neuronal proteins such as Huntington's disease, but it is also the case for common disorders such as cerebral ischaemia where the lack of energy can impair normal protein folding ${ }^{1}$ and sporadic Alzheimer's disease where protein aggregation causes cellular stress ${ }^{2-4}$. Even some infectious neurodegenerative disorders such as the prionopathies arise from abnormal

protein folding ${ }^{5-9}$. Consequently, the processes for disposing of misfolded proteins are the focus of much research. Although the subcellular location of protein misfolding may differ between these disorders, it appears that the interdependence of protein folding throughout the cell results in ER dysfunction being the final common pathway for many, if not all, of these diseases (Table 1).

\section{ER Dysfunction}

The endoplasmic reticulum (ER) is required for folding of all secreted and membrane proteins and insults that impair its function induce a pathological state termed 'ER stress' ${ }^{10}$. This triggers an adaptive programme called the Unfolded Protein Response (UPR), which combines the early inhibition of protein synthesis with a later upregulation of genes that promote protein folding or disposal ${ }^{10}$. Both the translational and transcriptional components of the UPR protect the neurone from becoming overwhelmed by misfolded ER proteins; however, when the insult is too great, apoptotic cell death frequently ensues. While many cells 
are relatively protected from accumulating misfolded protein through continued dilution of their ER by cell replication, this process is unavailable to post-mitotic neurones, which depend exclusively on the UPR. Even glial cells, which can replicate, are susceptible to ER stress owing to their highly developed secretory pathway.

It is important that the UPR be distinguished from the less well-understood ER Overload Response (EOR) ${ }^{11}$. The former is triggered by protein misfolding within the ER lumen, while the latter occurs when well-folded or misfolded proteins accumulate and distend the ER. In this review, we will discuss the relevance of these forms of ER dysfunction to neurological disease, since a better understanding of each is likely to identify novel therapeutic strategies (Panel 1). We will focus on ischaemic stroke, Alzheimer's disease and Parkinson's disease to discuss ER stress, while using Familial Encephalopathy with Neuroserpin Inclusion Bodies (FENIB) to illustrate ER overload, since these are the diseases for which the most evidence currently exists. In addition, we will discuss the evidence for ER dysfunction in multiple sclerosis, amyotrophic lateral sclerosis and the prion disorders. Some neurological disorders provoke ER stress signalling despite being caused by the accumulation of protein within the cytoplasm, for example Huntington's disease ${ }^{12}$. Such disorders emphasise the interdependence of protein folding networks in the neurone and so shall be discussed as examples of disordered protein homeostasis or 'proteostasis'. 


\section{ER stress signalling}

The signalling pathways triggered by ER stress comprise the UPR ${ }^{10}$ (Figure 1 ). Although it may seem tiresome to dwell on individual molecular components, this is unavoidable when studying a phenomenon as complex as ER stress. Not least, because many of the measures commonly used to detect and quantify ER stress are themselves components of the UPR. Some of these are activated transiently and so their absence cannot be used as evidence for a lack of ER stress ${ }^{10,13}$; conversely, certain components can be activated by stresses other than ER protein misfolding and so need to be interpreted with caution. We shall therefore begin with a review of the major mediators of ER stress signalling with an emphasis on their role in neurones before moving on to considering specific examples of neuropathology mediated by ER dysfunction.

\section{- PERK}

Whenever misfolded protein accumulates in the ER lumen, new protein synthesis is rapidly inhibited ${ }^{14}$. This occurs because ER stress activates the PKR-like Endoplasmic Reticulum elF2 $\alpha$ Kinase (PERK), also know as Pancreatic elF2 $\alpha$ kinase (Pek) because of the tissue in which it was first discovered ${ }^{14}$. This kinase is ubiquitously expressed but is most important in highly secretory tissues such as the brain where it functions to match protein synthesis with the efficiency of protein folding in the ER ${ }^{15}$. When protein folding is progressing well PERK is inactive, but when misfolded ER proteins accumulate the kinase is activated and phosphorylates eukaryotic translation initiation factor $2 \alpha\left(\right.$ elF2 $\alpha$ ) (Figure 1) ${ }^{16}$. 
This substrate is a subunit of the heterotrimeric GTP-binding complex elF2 that regulates the initiation of protein synthesis ${ }^{14}$. EIF2 recruits the methionyl-tRNA to the ribosome at the onset of protein translation, but when its elF2 $\alpha$ subunit is phosphorylated this activity is lost and translation ceases. The load of proteins entering the ER is thus reduced following PERK activation preventing the accumulation of more misfolded proteins.

\section{- ATF4}

Despite the inhibition of protein translation that accompanies phosphorylation of elF2 $\alpha$, a small subset of mRNAs is translated more efficiently under these conditions ${ }^{17}$. The best characterised of these is Activating Transcription Factor 4 (ATF4), which triggers a transcriptional programme of stress-responsive genes

17. Other members of the elF2 $\alpha$ kinase family can inhibit translation and activate these genes; for example PKR responds to viral infection, HRI to iron deficiency and GCN2 to amino acid starvation ${ }^{18}$. This ability of elF2 $\alpha$ phosphorylation to mediate a response to multiple stresses led to this pathway being named the Integrated Stress Response ${ }^{19}$. Surprisingly, within the brain this can provoke specific behavioural responses. A lack of essential dietary amino acids triggers the phosphorylation of eIF2 $\alpha$ in the anterior piriform cortex by GCN2, which alters feeding behaviour in rodents ${ }^{20,21}$. Thus, phosphorylation of elF2 $\alpha$ is not synonymous with ER stress and multiple lines of evidence should always be sought when attributing phosphorylation of elF2 $\alpha$ to ER dysfunction. 
Phosphorylation of elF2 $\alpha$ is particularly important for the maintenance of axonal myelination in the human central nervous system (Table 1); indeed mutations that disrupt the regulation of elF2 $\alpha$ result in white matter hypomyelination

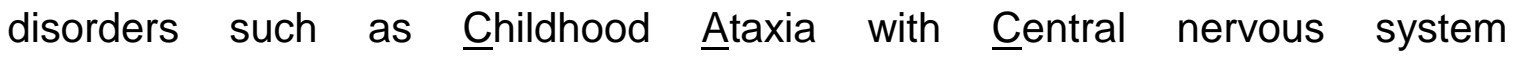
Hypomyelination (CACH syndrome) and Vanishing White Matter (VWM) ${ }^{22}$. This family of autosomal recessive conditions constitutes a spectrum of severity from congenital to adult-onset, involving the progressive loss of mental and motor function due to a loss of brain white matter. In all cases, the causative mutations are found within subunits of elF2B, a guanine nucleotide exchange factor (GEF) responsible for recharging the elF2 complex with GTP ${ }^{23,24}$ (Figure 1). These mutations interfere with the GEF activity of elF2B and enhance the synthesis of ATF4. This deregulates many target genes including components of a negative feedback system, including CHOP and GADD34, that normally recover protein translation following its initial inhibition by PERK ${ }^{13,25}$.

\section{- $\mathrm{CHOP}$}

The transcription factor CHOP is induced by ATF4 and has widely been thought to be pro-apoptotic during ER stress, since Chop-/- animals are resistant to ER stress-induced cell death ${ }^{13}$. However, this is inconsistent with observations made in neurological diseases. For example, CHOP expression is clearly antiapoptotic in mouse models of the X-linked disorder Pelizaeus-Merzbacher leukodystrophy caused by abnormalities of the proteolipid protein 1 (PLP1) gene

${ }^{26}$. Indeed, identification of the target genes of $\mathrm{CHOP}$ failed to reveal a link with 
apoptosis but instead identified genes that promote protein secretion ${ }^{13}$. This led us to suggest that in models of severe ER stress the promotion of protein secretion by $\mathrm{CHOP}$ might increase the intensity of stress and thus induce cell death ${ }^{13}$. By contrast, during conditions of milder ER stress, for example in Pelizaeus-Merzbacher leukodystrophy, it is likely that CHOP does not enhance ER stress sufficiently to trigger cell death ${ }^{26}$. These observations highlight the need to model not only the nature of the stress, but also its intensity and duration since differences in either can significantly affect the outcome and thus lead to beneficial or deleterious effects depending upon the context. There may also be cell type specific consequences of expressing CHOP. For example, while deletion of Chop worsens the central hypomyelination seen in PelizaeusMerzbacher leukodystrophy ${ }^{26}$, Chop-/- animals are protected against the peripheral hypomyelination caused by mutant myelin protein zero (P0) in mouse models of Charcot Marie Tooth type $1 \mathrm{~B}^{27}$.

\section{- GADD34}

A critical target gene of CHOP encodes Growth Arrest and DNA Damageinducible protein 34 (GADD34), which is a regulatory subunit of protein phosphatase $1(\mathrm{PP} 1)^{13}$. This dephosphorylates elF2 $\alpha$ and thus brings about the recovery of protein translation after its initial inhibition. It has been shown in mice that inactivation of the Gadd34 gene can protect animals from tissue damage during ER stress by reducing the accumulation of misfolded proteins ${ }^{13}$. Subsequently, a small molecule called salubrinal was identified that increases 
the level of elF2 $\alpha$ phosphorylation and promotes survival of ER-stressed cells ${ }^{28}$. It has been suggested that salubrinal may be an inhibitor of the elF2 $\alpha$ phosphatases ${ }^{28}$, but direct evidence for this is lacking. Recently, however, a selective inhibitor of GADD34, guanabenz, has been identified confirming the beneficial effects of GADD34 inhibition during ER stress at least in cultured cells 29. It is therefore likely that future therapies involving the inhibition of GADD34 will be able to modulate ER stress.

\section{- ATF6}

In addition to the Integrated Stress Response genes regulated by PERK and ATF4, many additional genes are induced during the UPR by two further ER stress sensors, Inositol-Requiring Enzyme 1 (IRE1) and Activating Transcription Factor 6 (ATF6) ${ }^{10}$ (Figure 1). Like PERK, both are ER membrane proteins that are held inactive under normal conditions by the binding of the ER chaperone Binding Immunoglobulin Protein (BiP; also known as GRP78). During stress, misfolded proteins sequester BiP, freeing ATF6 to traffic to the Golgi apparatus where it is cleaved to release a soluble transcription factor. Of note, astrocytes express an ATF6-related protein called OASIS (Old Astrocyte Specifically Induced Substance) whose functions appear to overlap partially with those of ATF6 ${ }^{30}$. This might enable astrocytes to respond to ER stress in a tissuespecific manner. 
While cleavage of ATF6 is strong evidence of ER stress, this is difficult to detect. Consequently, many studies fail to measure this arm of the UPR, but the use of sensitive reporters that measure the binding of ATF6 to specific DNA sequences can circumvent this problem in vitro ${ }^{11}$.

\section{- IRE1}

The activation of IRE1 closely resembles that of PERK but, unlike PERK, IRE1 triggers splicing of the mRNA encoding the transcription factor X-box Binding Protein $1(\mathrm{XBP} 1)^{31}$. This induces a frame shift that generates the active form of this protein. Like phosphorylation of elF2 $\alpha$, the splicing of XBP1 mRNA is transient ${ }^{13}$. Following the alleviation of ER stress by the induction of UPR target genes, spliced $X B P 1$ mRNA is rapidly lost from the cell to be replaced by the unspliced form ${ }^{13}$. In laboratory studies, supra-physiological levels of ER stress can cause complete splicing of XBP1 mRNA, but in vivo stresses are frequently subtler and so it is rare to observe complete splicing and careful quantification is therefore necessary ${ }^{32}$.

If proteins fail to fold in the ER, they are prevented from progressing along the secretory pathway and eventually are targeted for degradation ${ }^{33}$. This 'ERassociated protein degradation' (or ERAD) returns terminally misfolded proteins to the cytosol where they are ubiquitinated by ER-associated ubiquitin ligases for degradation by the proteasome ${ }^{34}$. Many components of the ERAD machinery 
are target genes of XBP1 and so the capacity for ERAD is increased by activation of IRE1 ${ }^{35}$.

\section{ER dysfunction in neurological disease}

\section{Cerebral hypoxia}

In industrialized countries stroke is the third biggest killer and the leading cause of disability in adults. Acute ischaemia is the main cause of neuronal loss and, although its pathology is complex, appears to involve ER stress ${ }^{1,15,36-38}$. During cerebral ischaemia, neuronal depolarization due to energy depletion causes the uncontrolled release of glutamate. The consequent activation of NMDA receptors on nearby neurones generates further glutamate release and causes an ischaemic depolarization wave to spread outward from the initial site of damage leading to widespread disturbance of calcium homeostasis ${ }^{39}$. Unsurprisingly, many studies implicate ER calcium store release in the resulting excitotoxic death (reviewed in reference ${ }^{39}$ ).

The ER is the main site for calcium storage within the cell and so its chaperones have evolved to function efficiently in this high calcium environment; indeed many require high calcium to function ${ }^{40}$. Calcium is pumped into the ER by the sarcoendoplasmic reticular calcium-ATPase (SERCA) and released back into the cytosol by the inositol trisphosphate receptor (IP3R) in response to extracellular signals and by the ryanodine receptor during calcium-induced calcium release ${ }^{39}$. Inhibition of the SERCA pump by thapsigargin induces apoptosis in many cell 
types including neuroblastoma cells and is often used to induce ER stress in the experimental setting ${ }^{41}$. During cerebral ischaemia, energy depletion leads to failure of the SERCA pump and thus redistribution of ER calcium into the cytosol. This delivers a double blow with combined toxicity from uncontrolled cytosolic calcium and ER stress due to chaperone dysfunction (Figure 2$)^{39}$.

The UPR is activated in many rodent models of cerebral ischaemia ${ }^{1,36}$. In these models, protein synthesis is rapidly inhibited and accompanies the phosphorylation of elF2 $\alpha$. Although the inhibition of translation has been attributed to aggregation of components of the translation machinery ${ }^{42}$, the primary mechanism appears to be through phosphorylation of elF2 $\alpha^{43}$, which can remain phosphorylated for up to twelve hours following ischaemia ${ }^{44}$. PERK is the sole elF2 $\alpha$ kinase activated by cerebral ischaemia and predictably Perk-/mice fail to show elF2 $\alpha$ phosphorylation following transient cerebral ischaemia and fail to reduce protein translation during the reperfusion period ${ }^{15}$. Even with the far milder recurrent cerebral hypoxia seen in obstructive sleep apnoea, activation of PERK has been described and has been suggested to play a role in the loss of upper airway motor neurones in this condition ${ }^{45}$.

IRE1 is also activated during cerebral ischaemia leading to the induction of UPR target genes ${ }^{37,38}$. It appears to promote activation of pro-apoptotic caspase-12 in cultured rodent cells and this has been detected in ischaemic rodent brains ${ }^{46}$. However, caspase-12 is non-functional in the majority of humans, except those 
from sub-Saharan Africa, owing to a common truncating mutation ${ }^{47}$. For this reason, it has been proposed that during ER stress in humans, caspase-4 might serve an analogous function to that of caspase-12 in rodents ${ }^{48}$.

Due to the problems of detection referred to earlier, the role of ATF6 during ischaemia is unclear. ATF6 gene expression is elevated following transient middle cerebral artery occlusion in rats ${ }^{36}$, but its activation has not been detected in rat brain following cardiac arrest and resuscitation ${ }^{49}$. OASIS is also upregulated and appears to play a neuroprotective role in response to kainate excitotoxicity ${ }^{50}$.

$\mathrm{CHOP}$ is induced following forebrain ischaemia in a variety of rodent models including bilateral common carotid ${ }^{51,52}$ or middle cerebral artery occlusion in mice ${ }^{44}$ and global cerebral ischaemia in rats ${ }^{53}$. The location within the brain of CHOP induction appears to correlate well with subsequent cell death ${ }^{53,54}$ and deletion of the Chop gene protects mice during bilateral common carotid artery occlusion ${ }^{52}$. Similarly, depletion of CHOP using RNA interference partially prevents the death of astrocyte cultures stressed by oxygen-glucose depletion ${ }^{55}$. As discussed, some of the toxicity attributable to $\mathrm{CHOP}$ reflects increased protein translation mediated by GADD34 ${ }^{13}$. Indeed, GADD34 induction is wellrecognised to accompany cerebral ischaemia ${ }^{56}$ being detected at the peri-infarct penumbra within two to twenty-four hours ${ }^{57}$ and accounts for the transient nature of elF2 $\alpha$ phosphorylation during stroke ${ }^{15}$. Attenuation of translation protects the 
cell from accumulating misfolded proteins, thus treatment with salubrinal (a drug that enhances elF2 $\alpha$ phosphorylation) reduces ER stress and promotes cellular survival in kainate-induced neurotoxicity ${ }^{58}$. Indeed, salubrinal has been shown to limit infarct size in a murine model of stroke ${ }^{1}$.

In addition to attenuating protein translation, the UPR leads to upregulation of ER molecular chaperones, the most abundant being BiP ${ }^{10}$. Following transient forebrain ischaemia, BiP expression in the hippocampus and cortex peaks between twelve to seventy-two hours after reperfusion ${ }^{54,59}$, but can remain elevated for up to two weeks ${ }^{36}$. This is protective, since suppression of BiP enhances apoptosis in hippocampal neurones exposed to excitotoxic and oxidative insults ${ }^{60}$, while its overexpression in primary astrocyte cultures is protective against oxygen-glucose deprivation ${ }^{61}$. Indeed, higher levels of BiP induction correlate with neuronal protection ${ }^{37,62}$.

Induction of the ER chaperone ORP150 (150-kDa oxygen-regulated protein) is also seen in ischaemic neurones, and over-expression of ORP150 protects mice from cerebral ischaemia ${ }^{63}$. ORP150 modulates the activity of BiP, which exists in either an ATP- or ADP-bound form, each with different substrate-binding affinity. ORP150 functions as a nucleotide exchange factor for BiP to replace its bound ADP with ATP. Interesting, another BiP nucleotide exchange factor, SIL1, is mutated in the Marinesco-Sjogren syndrome of cerebellar ataxia in which homozygous loss of SIL1 leads to ER stress and selective loss of cerebellar 
Purkinje cells ${ }^{64}$. When ATP-BiP binds its substrate protein, a co-chaperone of the DnaJ family is required to stimulate BiP's ATPase activity and so promote high affinity substrate binding. The relative levels of ADP-BiP and ATP-BiP appear to be important for neuronal survival, since the toxicity of SIL1 loss can be ameliorated by the deletion of an ER luminal DnaJ co-chaperone called p58 $8^{\mathrm{IPK}}$ 65. While loss of SIL1 would be predicted to reduce the level of ATP-BiP through impaired nucleotide exchange, loss of $\mathrm{p} 58^{\mathrm{IPK}}$ is likely to restore balance by lessening BiP's ATPase activity.

When taken together, these observations suggest that ER stress is induced by cerebral ischaemia and that the UPR limits cerebral infarct size. There is good evidence to suggest that manipulation of ER stress signalling by increasing phosphorylation of elF2 $\alpha$ may have important therapeutic effects as an acute intervention for cerebral ischaemia.

\section{Alzheimer's disease}

Often presenting with failing memory, Alzheimer's disease (AD) is a relentlessly progressive neurodegenerative disorder and the most common cause of dementia in adults. The classic histopathological features consist of extracellular plaques of the $\beta$-amyloid $(A \beta)$ peptide and intracellular neurofibrillary tangles of hyperphosphorylated aggregates of the microtubule-associated protein tau. Studies of familial AD demonstrate that the disorder is caused by overproduction of the more aggregation-prone $A \beta_{1-42}$ peptide ${ }^{66}$ (Figure 3). Despite decades of 
study, the molecular pathology of this disease remains unclear. However, increasing evidence suggests that ER stress may represent a new paradigm for understanding this condition.

Studies using post-mortem tissue from the brains of individuals with $A D$ have provided evidence for ER dysfunction in this disease. But when looking at a single marker of ER stress, such studies can generate confusing results. For example, when BiP is examined in isolation it can show no change ${ }^{3}$, a decrease ${ }^{67}$ or even an increase ${ }^{2,68}$, although BiP expression does seem to be higher in brains with histologically more advanced disease ${ }^{68,69}$. However, whilst often a useful indicator, the level of $\mathrm{BiP}$ expression is inadequate alone to assess the activation of UPR signalling, especially in a chronic disorder in which histological features evolve over time. It has therefore proved more useful to include additional markers of the UPR in such studies. For example, protein disulphide isomerase, another target of the UPR, is elevated in the temporal lobes of the brains of individuals with $A D^{3}$, associated with neurofibrillary tangles in the hippocampus and frontal lobes and in dystrophic neurites of senile plaques ${ }^{4}$. When one looks for more proximal markers of UPR signalling, there is activation of PERK in the hippocampus of AD brains, which appears to co-localise with staining for phosphorylated tau and correlates with histological staging ${ }^{70,71}$. Yet phosphorylated PERK is barely detectable in tangle-bearing neurones themselves, suggesting that PERK is activated at the pre-tangle stage in neurones of the hippocampus ${ }^{71}$. In addition, there are elevated levels of spliced 
$X B P 1$ mRNA in the temporal cortex of $A D$ patients when compared to agematched controls ${ }^{3}$. Congruently, a marked increase in the number of neurones immunoreactive for phosphorylated (active) IRE1 $\alpha$ has been detected in the hippocampus of individuals with $A D^{71}$.

There is good evidence for activation of PERK in laboratory models of AD. Increased BiP expression observed upon application of exogenous $A \beta$ to primary cortical neurones suggests that accumulation of the peptide may directly activate ER stress signalling ${ }^{72,73}$. Moreover, exogenous $A \beta$ has been found to increase the phosphorylation of PERK and elF2 $\alpha$ in cultured neuronal cells ${ }^{73,74}$, while silencing of PERK by siRNA in $A \beta_{42}$-treated cells limits elF2 $\alpha$ phosphorylation and enhances cell death ${ }^{73}$. In addition, $A \beta_{42}$ treatment induces $\mathrm{CHOP}$ expression both in cultured cells and in rabbit hippocampus ${ }^{75,76}$, while prior treatment of cells with $\mathrm{CHOP}$ anti-sense RNA improves survival following exposure to the $A \beta$ peptide, suggesting a role for $C H O P$ in $A \beta$-mediated death ${ }^{77}$. In Drosophila neurones or mammalian PC-12 cells, exposure to $A \beta$ induces XBP1 mRNA splicing and in both models overexpression of spliced XBP1 is protective, while knockdown of XBP1 exacerbates $A \beta$ toxicity ${ }^{78}$.

PC-12 cells overexpressing mutant forms of presenilin 1 (PS1), a component of the $\gamma$-secretase, that has been linked to familial AD, show increased levels of phosphorylated elF2 $\alpha$, as do hippocampal homogenates from PS1 mutant knock-in mice ${ }^{79}$. PC-12 cells expressing mutant PS1 have elevated levels of 
CHOP, as do knock-in mice expressing mutant PS1 ${ }^{79}$. The nature of the interaction between PS1 and ER stress has yet to be fully elucidated, although it is known that PS1 and the SERCA calcium pump physically interact with one another ${ }^{80}$. As discussed, disordered calcium homeostasis is a potent cause of ER stress and much evidence suggests that calcium signalling is perturbed in Alzheimer's disease ${ }^{81}$ (reviewed in reference ${ }^{82}$ ). Interestingly, ER stress induced by tunicamycin, a glycosylation inhibitor frequently used to induce ER stress in vitro, increases PS1 expression in multiple cell lines including neuroblastoma ${ }^{80}$. Recent evidence suggests that phosphorylation of elF2 $\alpha$ by PERK during ER stress can increase the level of $\beta$-site APP cleaving enzyme-1 (BACE) and thereby promoting amyloid formation ${ }^{83}$. This suggests that the interaction between $A D$ and ER stress may prove to be bi-directional.

ER stress has been shown to alter APP localization, processing and degradation by the ERAD machinery ${ }^{84}$ (Figure 4). During ER stress, immature forms of APP bind to $\mathrm{BiP}$ and when $\mathrm{BiP}$ is overexpressed $\mathrm{A} \beta$ generation is reduced as APP is retained in earlier compartments of the secretory pathway ${ }^{84}$. The ERAD ubiquitin ligase HRD1 promotes APP ubiquitination and degradation in HEK293 cells reducing the generation of both $A \beta_{40}$ and $A \beta_{42}{ }^{2}$. In addition, an intronic polymorphism (IVS3-88A $>$ G) of $S E L 1 L$, another component of the ERAD system, has been associated with $A D$ in an Italian population ${ }^{85}$. These hints that ERAD is important in the pathogenesis of $A D$ still require further validation. But there is accumulating evidence for elevated UPR signalling in AD and, combined with the 
support from model systems, provides a potential mechanism by which the $A \beta$ peptide and mutants of PS1 might induce ER stress. This offers the potential to identify new therapeutic targets in an otherwise incurable disease.

\section{Parkinson's disease}

With age, $2 \%$ of the population suffer the loss of dopaminergic neurones in their nigrostriatal pathway and so develop Parkinson's disease (PD) characterised by hypokinesia, rigidity and tremor. Post-mortem studies identify characteristic Lewy body inclusions in many affected brains, suggesting aberrant protein disposal as a possible cause, while toxins that cause Parkinsonism, such as MPTP, rotenone and 6OHDA, impair mitochondrial function and promote ER stress ${ }^{86-90}$.

Multiple lines of evidence point towards a role for ER stress in the pathogenesis of PD. For example, excess levels of dopamine are toxic to PC-12 cells, which correlates with their induction of ER chaperones ${ }^{91}$. The brains of patients suffering from sporadic PD, but not controls, have elevated levels of phosphorylated PERK and elF2 $\alpha^{92}$. Perk-/- sympathetic neurones are hypersensitive to $6 \mathrm{OHDA}{ }^{92}$, while overexpression of spliced XBP1 is protective both in cultured cells and animals treated with MMP+/MPTP ${ }^{87}$. CHOP expression is increased both by 6OHDA and MPTP, and knockout of the Chop gene is protective in mice treated with 6OHDA ${ }^{93}$. 
In Japanese and European families with the juvenile onset autosomal recessive variant of PD (ARPD), classical genetic mapping identified the diseaseassociated gene PARK2 ${ }^{94}$. This encodes an ubiquitin ligase Parkin, whose activity is lost with disease-associated mutations ${ }^{95}$. Parkin was suggested to localize to the ER and to be upregulated during the UPR ${ }^{96}$. A major function of Parkin appears to involve targeting defective mitochondria for destruction by autophagy ${ }^{97}$. It is possible that impaired mitochondrial function in patients with PARK2 mutations manifests as ER stress owing to defects in energy supply during ER protein folding. However, another component of Lewy bodies, $\alpha-$ synuclein, can be found throughout the cell including the ER lumen and may also be a target of Parkin ${ }^{98}$. Mutations of $\alpha$-synuclein cause an autosomal dominant form of PD ${ }^{99}$, while the glycosylated ER-form of $\alpha$-synuclein has been shown to be ubiquitinated by Parkin and to accumulate in a non-ubiquitinated form in the brains of individuals with Parkin deficiency ${ }^{98}$. Overexpression of $\alpha$-synuclein induces ER stress ${ }^{100}$, perhaps through binding to $\mathrm{BiP}{ }^{101}$, while PDI appears to impair $\alpha$-synuclein fibril formation ${ }^{100}$. Recently, oligomers of mutant $\alpha$-synuclein were shown to accumulate within the ER in an animal model and to trigger the UPR, albeit with relatively little PERK activation ${ }^{102}$. When elF2 $\alpha$ phosphorylation was augmented with salubrinal, the accumulation of $\alpha$-synuclein oligomers was ameliorated and disease onset was delayed. There is further evidence that modulating the levels of ER stress may be beneficial in PD, since 4-PBA, which has been shown to possess 'chemical chaperone activity' that can protect cells from ER stress, rescues cells from the neurotoxicity of rotenone ${ }^{103}$ and 'pre- 
conditioning' neuroblastoma cells with ER stress to up-regulate chaperone levels can protect the cells from subsequent challenge with 6OHDA ${ }^{104}$.

\section{Huntington disease}

Huntington disease (HD) is an inherited autosomal dominant disorder characterised by motor dysfunction, psychiatric disturbances and intellectual decline. It is caused by expansions of CAG repeats within the HTT gene encoding huntingtin and so represents an archetypal poly-Q disease. In health, the normal HTT gene contains 6 to 35 repeats, while in patients affected by HD there may be more than 40 , which generates a protein prone to aggregation. Although this aggregation takes place in the cytosol this has been shown to provoke ER stress ${ }^{105}$.

It is now appreciated that perturbations of protein folding within one organelle can be propagated to another. This concept of cell-wide protein homeostasis, or 'proteostasis', may be especially relevant to HD and other poly-Q disorders wherein cytoplasmic aggregates trigger the UPR ${ }^{106}$. The precise mechanism linking aggregation in the cytosol with malfunction of the ER is poorly understood; however, expression of poly-Q proteins and mutant huntingtin in cells has been shown to bind components of the ERAD machinery and impair their function ${ }^{12}$, 107. It is possible that huntingtin is a target of the ERAD ubiquitin ligase HRD1,

since HRD1 can ameliorate the toxicity of the poly-Q protein ${ }^{107}$. By sequestering HRD1 and other components, huntingtin might reduce the capacity of a neurone 
to cope with misfolded proteins by ERAD, thereby rendering them more vulnerable to ER stress ${ }^{12}$. In addition, while chronic ER stress is known to induce cell death in some circumstances, it might also impair intracellular signalling in viable cells. Recent data suggest that ER calcium release via the IP3R1 channel is impaired by ER stress in HD owing to the loss of a stimulatory interaction between BiP and this channel ${ }^{108}$.

\section{Amyotrophic lateral sclerosis}

Amyotrophic lateral sclerosis (ALS) involves the progressive loss of motor neurones causing an irreversible decline of muscle power and death usually within five years. The aetiology remains largely unknown, although $5-10 \%$ of cases display a dominant pattern of inheritance suggestive of a toxic-gain-offunction, so-called Familial ALS (FALS). Of these, a fifth are caused by mutations in the copper-zinc superoxide dismutase 1 (SOD1) that accumulates as fibrils in Lewy Body-like hyaline inclusions, the histological hallmark of FALS.

Post-mortem brains from ALS patients show elevated levels of markers of ER stress ${ }^{109}$. Furthermore, disease models of FALS implicate ER stress in its pathogenesis. Although SOD1 was thought to be an abundant cytosolic protein, it is also secreted by multiple cell types and co-localises with ER markers ${ }^{110}$. When expressed in cultured cells or in animal neuronal tissue, mutant SOD1 accumulates within the ER and upregulates targets of the UPR ${ }^{111-113}$. 
Activation of PERK can be detected in animals prior to the development of overt disease ${ }^{114}$ and it has been shown in three models of FALS that a subset of motor neurones are more sensitive to the toxic effects of mutant SOD1 and show evidence of ER stress at a younger age ${ }^{115}$. When one allele of Perk is deleted in mice expressing a mutant form of SOD1, onset of disease is accelerated, suggesting that phosphorylation of elF2 $\alpha$ is protective in this disorder ${ }^{116}$. This is supported by the protection of vulnerable neurones in animals treated with salubrinal ${ }^{115}$.

Surprisingly, deletion of neuronal XBP1 has been shown to delay the onset of disease extending the lives of FALS mice ${ }^{117}$. In cultured neurones depletion of XBP1 reduces SOD1 aggregates and toxicity through enhanced autophagy, which might plausibly explain this apparent neuroprotection through increased clearance of aggregated protein. Similarly, enhanced degradation of SOD1 by overexpression of ERAD protein derlin1 ameliorates SOD1-induced cell death 118. Though mutant SOD1 has been shown to interact with derlin1 and so impair ERAD to promote ER stress ${ }^{119}$.

\section{Multiple sclerosis}

Regulated phosphorylation of elF2 $\alpha$ is important for the health of myelinated neurones within the central nervous system as illustrated by the $\mathrm{CACH} / \mathrm{VWD}$ syndrome and Pelizaeus-Merzbacher leukodystrophy as mentioned previously. This holds true in multiple sclerosis (MS), although the timing of elF2 $\alpha$ 
phosphorylation relative to the onset of disease determines its consequences. In the experimental autoimmune encephalitis (EAE) model of MS, ER stress can hasten or delay disease progression if induced after of before disease onset respectively ${ }^{120,121}$; a phenomenon previously seen with interferon treatment. Indeed, both EAE and interferon cause phosphorylation of elF2 $\alpha$ by PERK. Only when animals are exposed to interferon prior to EAE is a protective 'preconditioning' seen and, importantly, the protection is lost if one allele of Perk is deleted ${ }^{120}$. In contrast, interferon treatment of animals with established EAE exacerbates their ER stress and worsens demyelination through impaired oligodendrocyte survival.

\section{FENIB}

Ten years ago, the first cases of a new familial encephalopathy with inclusion bodies (FENIB) were described in two families living in the USA ${ }^{122}$. The primary symptom of this autosomal dominant neurodegenerative disease was pre-senile dementia. In each family, eosinophilic neuronal inclusions were observed in the deeper layers of the cerebral cortex and in the substantia nigra (Figure 5). After isolation and sequencing of these inclusions, it was demonstrated that they were composed of a single protein, neuroserpin. When expressed in neurones, the mutants of neuroserpin accumulate to form acid-Schiff-positive diastase-resistant inclusions in the ER, also called Collins' bodies ${ }^{122}$. 
Neuroserpin is a member of the serine protease inhibitor (serpin) superfamily. Serpins are capable of polymerisation under certain circumstances and many examples of naturally occurring mutations exist that promote polymerisation leading to disease ${ }^{123,124}$. The retention of polymerised neuroserpin within the ER causes neurotoxicity through a toxic gain-of-function, while the lack of secretion causes the activation of proteolysis and hence disease through a lossof-function ${ }^{123}$.

Despite being retained in the ER, the polymerised mutants of neuroserpin fail to activate the UPR ${ }^{11}$. Instead, these polymers induce NFKB signalling in a calcium-dependent manner ${ }^{11}$. This is reminiscent of the ER overload response (EOR), which is activated by the accumulation of well-folded protein as happens, for example, in some viral infections ${ }^{125}$. The degradation of mutant neuroserpin involves the co-ordinated activity of both the ERAD and autophagic pathways ${ }^{124}$. Since these pathways have successfully been targeted in preclinical studies of a related serpinopathy using the drug carbamazepine ${ }^{126}$, there is hope for pharmacological treatment of this and other ER overload disorders. Indeed, it is likely that similar strategies will prove beneficial in other diseases of protein accumulation, such as those described in the sections concerning ER stress.

\section{Prion diseases}

The nature of the ER dysfunction observed in prion diseases remains less clear. While ER stress pathways were activated in a cell model of Creutzfeldt-Jakob 
disease (CJD), UPR signalling was not detected in a transgenic mouse model for prion disease ${ }^{5}$. Nevertheless, both primary neuronal cultures and PC-12 cells expressing PrP mutants develop dramatic ER swelling suggesting that ER homeostasis is perturbed ${ }^{6}$. The failure to detect splicing of XBP1 mRNA or differences in BiP levels in prion disease models suggests that prion proteins might not elicit classical ER stress ${ }^{5}$. However, pharmacological induction of ER stress in neuronal cell lines expressing mutant PrP can decrease PrP levels ${ }^{7}$. Recently it was shown that prion replication causes prolonged repression of protein translation leading to synaptic failure of neuronal loss ${ }^{9}$. In contrast to many ER stress-related disorders in which enhanced phosphorylation of elF2 $\alpha$ is protective, prion-induced neurodegeneration is enhanced by salubrinal while overexpression of GADD34 is protective. The relationship between the prionopathies and ER dysfunction therefore requires further examination.

\section{Concluding remarks and therapeutic potential}

The evidence for activation of ER stress responsive pathways in a range of neurological conditions is strong. What remains to be determined is how successful strategies that target these responses will be in treating these

diseases. The UPR signalling field has matured to a point at which small molecular inhibitors of its components are now being developed.

The muscle relaxant dantrolene targets IP3R channels of the ER to prevent the release of calcium. This provides neuroprotection in models of HD ${ }^{127}$ and of 
cerebral hypoxia-reperfusion injury, where its action is associated with reduced levels of ER stress ${ }^{128}$. Prolonging the phosphorylation of elF2 $\alpha$ and thus delaying the recovery of protein translation with agents such as salubrinal or guanabenz is another promising approach ${ }^{28,29}$. Salubrinal has already been shown to reduce the accumulation of $\alpha$-synuclein in models of $A L S^{102,129}$, reduce the toxicity of $A \beta$ to primary neurones ${ }^{73}$, and lessen the ER stress associated with cerebral ischemia/reperfusion and models of $\mathrm{HD}{ }^{1,}{ }^{130}$. More recently, agents have been developed that inhibit IRE1, including quinotrierixin ${ }^{131}$ and $4 \mu 8 \mathrm{C}{ }^{132}$. Both selectively inhibit the splicing of XBP1 mRNA and the latter prevents expansion of the ER without obvious toxicity, which might have therapeutic utility to impede the formation of protein inclusions in neurones.

The list of neurological disorders with impaired ER protein folding is already long and appears set to grow further for some time to come (Table 1). It will therefore aid the neurologist and neuroscientist alike to appreciate the signalling pathways that communicate this failure of ER function to the rest of the cell, since it is likely these insights will inform research, diagnosis and ultimately therapy.

\section{Acknowledgements}

Our labs are funded by grants from the MRC and ART and by Papworth NHS Trust. AJK is a Wellcome Trust PhD student and SJM is an MRC Senior Clinical Fellow (MRC Ref G1002610). DCC is an Alzheimer's Research UK Senior Research Fellow and is supported by the MRC and EPSRC (MRC Ref 
G0700990). EM is funded by the Pasteur Institute-Cenci Bolognetti Foundation and by the Telethon Foundation.

\section{Contributions and conflicts of interest}

BDR and SJM planned and wrote the review. All authors commented on the final manuscript. BDR performed the literature search for and wrote the stroke, Parkinson's and Huntington's disease, multiple sclerosis and prionopathy sections and prepared figure 1. AJK performed the literature search for Alzheimer's disease, and contributed to drafting the Alzheimer's disease section and figure. EM helped draft the FENIB section. DCC helped draft the Alzheimer's section. DAL helped draft the FENIB section. SJM performed the literature search for ER stress and supervised the review project. 


\section{Panel 1}

\section{Search Strategy}

We set out by searching the PubMed database with the terms "(endoplasmic reticulum) AND (brain OR neurological) AND disease" including only articles in English. These titles and abstracts were screened and relevant papers were obtained for detailed assessment. Their bibliographies were also screened for additional sources. Papers published prior to September 2012 are included. Where possible, emphasis is given to articles published within the last 5 years.

\section{Figure legends}

Figure 1. Endoplasmic reticulum stress signalling In health, newly synthesised secretory proteins are translocated into the ER lumen co-translationally. They fold with the aid of chaperones, for example BiP. When recognised as correctly folded they exit the ER in COPII-coated vesicles and traffic along the secretory pathway. During ER stress, misfolded proteins accumulate in the ER lumen and sequester BiP from the sensor molecules PERK, IRE1 and ATF6. PERK phosphorylates elF2 $\alpha$, which binds and inhibits its guanine nucleotide exchange factor elF2B. This blocks new secretory protein synthesis and triggers the integrated stress response (ISR) through increased levels of ATF4. Activation of IRE1 leads to generation of active XBP1, while 
cleavage of ATF6 generates ATF6c. These transcription factors co-operate to induce target genes of the unfolded protein response (UPR).

\section{Figure 2. ER stress during cerebral ischaemia}

During an ischaemic stroke, the lack of glucose and oxygen supply in neurones induces a dramatic fall in ATP production. Without energy, BiP binds to unfolded proteins less efficiently resulting in the accumulation of misfolded ER client proteins and subsequent activation of the UPR. In parallel, failure of the SERCA pump depletes ER calcium and worsens chaperone function still further. Extracellular tPA (tissue-type plasminogen activator) cleaves the NMDA receptor allowing calcium influx into the cytosol. The resultant elevation of cytosolic calcium triggers calcium-induced calcium release via ryanodine receptors located in the ER membrane leading to calcium depletion from the ER. In severely affected neurones, elevated cytosolic calcium ultimately induces cell death. In

surviving neurones, induction of the elF2 $\alpha$ phosphatase GADD34 by ATF4 in a CHOP-dependent manner enables the eventual recovery of protein translation. This can contribute to reperfusion injury through increasing the level of ER protein load.

\section{Figure 3. Alzheimer's disease and ER stress}

(A) In health, amyloid precursor protein (APP) is cleaved sequentially by $\beta$ secretase followed by $\gamma$-secretase in the TGN and early endosomes mainly 
generating non-toxic $A \beta_{40}$. APP is recycled via the endosomal pathway. (B) In Alzheimer's disease, toxic $A \beta_{42}$ is generated and secreted. Exogenous $A \beta_{42}$ causes ER stress via a poorly understood mechanism. In some cases of familial Alzheimer's disease, mutations in PS1 impair trafficking of APP, thereby enhancing $A \beta_{42}$ secretion. Mutated PS1 may also lead to APP processing within the ER.

\section{Figure 4: ERAD of amyloid precursor protein}

Newly synthesised proteins, for example amyloid precursor protein (APP), interact with ER chaperones during multiple folding cycles until they reach their native folded state. Overexpression of BiP can increase retention of APP in the ER. If protein folding fails, the terminally misfolded client is targeted for degradation via ERAD. The interaction of glycoprotein substrates with both the folding machinery and the ERAD machinery is governed by cycles of demannosylation and re-mannosylation. Eventually, low mannose species can interact with EDEM and be targeted for dislocation from the ER lumen into the cytosol. This process is incompletely understood and displays substrate specific differences, but for APP involves a complex containing Hrd1 and Sel1L. Once in the cytosol, the ERAD substrate is ubiquitinated and eventually degraded by the proteasome. 
Figure 5: FENIB and the ER overload response

(A) Eosin staining of cerebral cortex from individuals with wild-type neuroserpin (WT) and the S52R or G392E mutations. Mutant protein is retained as polymers within the ER to form Collins bodies (red). The rate of polymer formation correlates with the age at which symptoms develop and the amount of Collins' bodies that can be detected. (B) Monomeric serpins, for example neuroserpin, present a reactive centre loop (red) that functions as a pseudosubstrate for their target protease. However, point mutations in the shutter domain (purple circle) open $\beta$-sheet $A$ (green) to allow the insertion of the reactive centre loop belonging to a second serpin molecule. If allowed to propagate, this loop-sheet linkage generates large stable pathological polymers that are retained in the ER to form Collins' bodies. (C) These polymers are formed of folded neuroserpin and therefore fail to activate the UPR. Instead they cause the release of ER calcium into the cytosol, which causes $\mathrm{NF \kappa B}$ activation and target gene induction. 


\begin{tabular}{|c|c|c|c|c|}
\hline Disease & Neurological phenotype & Cause & $\begin{array}{l}\text { Proposed mechanism for } \\
\text { ER dysfunction }\end{array}$ & $\begin{array}{c}\text { Selected } \\
\text { references }\end{array}$ \\
\hline $\begin{array}{l}\mathrm{CACH} / \mathrm{VWM} \\
\text { leukodystrophy }\end{array}$ & $\begin{array}{l}\text { Cerebellar ataxia } \\
\text { Central hypomyelination } \\
\text { Autosomal recessive }\end{array}$ & elF2B mutations & Enhanced ATF4 synthesis & $22-24$ \\
\hline $\begin{array}{l}\text { Pelizaeus- } \\
\text { Merzbacher } \\
\text { leukodystrophy }\end{array}$ & $\begin{array}{l}\text { Cerebellar ataxia } \\
\text { Central hypomyelination } \\
\text { X-linked }\end{array}$ & PLP1 gene duplication & $\begin{array}{l}\text { Accumulation of PLP1 } \\
\text { within the ER }\end{array}$ & 26 \\
\hline $\begin{array}{l}\text { Charcot-Marie } \\
\text { tooth type } 1 \mathrm{~A}\end{array}$ & $\begin{array}{l}\text { Peripheral sensory neuropathy } \\
\text { Peripheral demyelination } \\
\text { Autosomal dominant }\end{array}$ & $\begin{array}{l}\text { PMP22 mutation or } \\
\text { duplication }\end{array}$ & $\begin{array}{l}\text { Accumulation of myelin } \\
\text { protein PMP22 within the } \\
\text { ER }\end{array}$ & 133 \\
\hline $\begin{array}{l}\text { Charcot-Marie } \\
\text { tooth type 1B }\end{array}$ & $\begin{array}{l}\text { Peripheral sensory neuropathy } \\
\text { Peripheral demyelination } \\
\text { Autosomal dominant }\end{array}$ & MPZ mutation & $\begin{array}{l}\text { Presumed accumulation of } \\
\text { myelin protein PO within } \\
\text { the ER }\end{array}$ & 27 \\
\hline Multiple sclerosis & $\begin{array}{l}\text { Progressive motor and } \\
\text { cognitive impairment } \\
\text { Patchy central demyelination } \\
\text { Sporadic }\end{array}$ & $\begin{array}{l}\text { Inflammatory loss of } \\
\text { myelination }\end{array}$ & $\begin{array}{l}\text { Inflammation-driven } \quad \text { ER } \\
\text { stress }\end{array}$ & 120,121 \\
\hline $\begin{array}{l}\text { Marinesco- } \\
\text { Sjögren syndrome }\end{array}$ & $\begin{array}{l}\text { Cerebellar ataxia } \\
\text { Purkinje cell loss } \\
\text { Autosomal recessive }\end{array}$ & SIL1 gene mutation & $\begin{array}{l}\text { BiP dysfunction due to } \\
\text { impaired SIL1 nucleotide } \\
\text { exchange activity }\end{array}$ & 64,65 \\
\hline Alzheimer disease & $\begin{array}{ll}\text { Loss of cortical } & \begin{array}{l}\text { neurones } \\
\text { cognitive }\end{array} \\
\text { Progressive } & \\
\text { impairment } & \\
\text { Sporadic } & \\
\& & \end{array}$ & $\begin{array}{l}\text { Poorly understood } \\
\beta \text {-amyloid accumulation } \\
\text { hyperphosphorylation of } \\
\text { tau }\end{array}$ & $\begin{array}{l}\text { Impaired ER calcium } \\
\text { homeostasis } \\
\text { Direct } A \beta \text { toxicity }\end{array}$ & $\begin{array}{l}2-4,71-73,75,80, \\
81,83\end{array}$ \\
\hline
\end{tabular}




\begin{tabular}{|c|c|c|c|c|}
\hline & Autosomal dominant & & & \\
\hline $\begin{array}{l}\text { Parkinson } \\
\text { disease }\end{array}$ & $\begin{array}{l}\text { Progressive motor and } \\
\text { cognitive dysfunction } \\
\text { Sporadic } \\
\text { Autosomal Recessive } \\
\text { Autosomal Dominant }\end{array}$ & 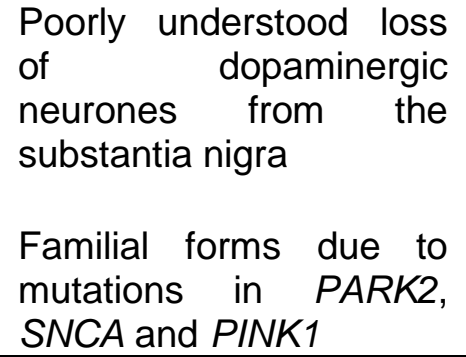 & $\begin{array}{l}\text { Impaired mitochondrial } \\
\text { ATP generation causing } \\
\text { secondary ER failure } \\
\text { ER accumulation of } \\
\text { aggregated synuclein }\end{array}$ & $\begin{array}{l}87,91,93,96,101- \\
104\end{array}$ \\
\hline $\begin{array}{l}\text { Huntington } \\
\text { disease }\end{array}$ & $\begin{array}{l}\text { Progressive motor and } \\
\text { cognitive dysfunction } \\
\text { Autosomal Dominant }\end{array}$ & $\begin{array}{l}\text { Expansion of CAG } \\
\text { repeats in the HTT gene } \\
\text { leading to selective } \\
\text { neuronal loss in caudate } \\
\text { and putamen }\end{array}$ & $\begin{array}{l}\begin{array}{l}\text { Failure of } \\
\text { likely due }\end{array} \text { to cytosolic } \\
\text { aggregates } \\
\text { impairing }\end{array}$ & $12,106-108$ \\
\hline $\begin{array}{l}\text { Amyotrophic } \\
\text { lateral sclerosis }\end{array}$ & $\begin{array}{l}\text { Progressive motor impairment } \\
\text { Sporadic } \\
\& \\
\text { Autosomal Dominant }\end{array}$ & $\begin{array}{l}\text { Poorly understood loss } \\
\text { of motor neurones } \\
\text { Some familiar forms due } \\
\text { to mutations in SOD1 } \\
\text { gene }\end{array}$ & $\begin{array}{l}\text { Accumulation of mutant } \\
\text { SOD1 within the ER }\end{array}$ & $109,111-116,119$ \\
\hline Prion diseases & $\begin{array}{l}\text { Spongiform encephalopathy } \\
\text { Infective } \\
\& \\
\text { Autosomal Dominant }\end{array}$ & $\begin{array}{l}\text { Propagation of infective } \\
\text { prion conformation of } \\
\text { PrP protein }\end{array}$ & $\begin{array}{l}\text { Impaired cellular } \\
\text { proteostasis } \\
\text { Possible direct ER toxicity }\end{array}$ & $5-7,9$ \\
\hline FENIB & $\begin{array}{l}\text { Progressive dementia and } \\
\text { epilepsy } \\
\text { Autosomal Dominant }\end{array}$ & Mutations of SERPINI1 & $\begin{array}{l}\text { Polymerised neuoserpin } \\
\text { accumulates within the ER } \\
\text { activating the ER overload } \\
\text { response }\end{array}$ & 11,124 \\
\hline $\begin{array}{l}\text { Tuberous } \\
\text { sclerosis complex }\end{array}$ & $\begin{array}{l}\text { Central hamartomas cause } \\
\text { epilepsy often with cognitive } \\
\text { and behavioural defects }\end{array}$ & $\begin{array}{l}\text { TSC1 and } \\
\text { mutations }\end{array}$ & $\begin{array}{l}\text { mTORC-mediated } \\
\text { impairment of ER stress } \\
\text { signalling }\end{array}$ & 134 \\
\hline
\end{tabular}




\begin{tabular}{|c|c|c|c|c|}
\hline & Autosomal Dominant & & & \\
\hline Epilepsy & $\begin{array}{l}\text { Progressive neuronal loss } \\
\text { Sporadic }\end{array}$ & Repeated seizure activity & $\begin{array}{l}\text { Incompletely understood } \\
\text { Likely involves disturbed } \\
\text { ER calcium homeostasis } \\
\end{array}$ & 135 \\
\hline $\begin{array}{c}\text { Wolfram } \\
\text { syndrome } 1\end{array}$ & $\begin{array}{l}\text { Diabetes insipidus, optic } \\
\text { atrophy, deafness } \\
\text { Autosomal Recessive }\end{array}$ & $\begin{array}{l}\text { Mutations of WFS1 } \\
\text { gene. }\end{array}$ & $\begin{array}{l}\text { WFS1 encodes an ER ion } \\
\text { channel whose dysfunction } \\
\text { induces ER stress }\end{array}$ & 136 \\
\hline Torsion dystonia 1 & $\begin{array}{l}\text { Involuntary sustained muscle } \\
\text { contraction } \\
\text { Autosomal Dominant }\end{array}$ & $\begin{array}{l}\text { Mutations in TOR1A } \\
\text { gene }\end{array}$ & $\begin{array}{l}\text { Impairment of Torsin A, an } \\
\text { AAA ATPase chaperone in } \\
\text { the ER }\end{array}$ & 137 \\
\hline $\begin{array}{l}\text { Lipid storage } \\
\text { disorders (e.g. } \\
\text { Gaucher disease) }\end{array}$ & $\begin{array}{l}\text { Progressive ataxia, mental } \\
\text { and motor deficiency } \\
\text { Autosomal Recessive }\end{array}$ & Mutations in GBA & $\begin{array}{l}\text { Disturbed ER calcium } \\
\text { homeostasis and } \\
\text { accumulation of mutated } \\
\text { protein within the ER }\end{array}$ & 138 \\
\hline $\begin{array}{l}\text { Cerebral } \\
\text { ischaemia }\end{array}$ & $\begin{array}{l}\text { Neuronal death } \\
\text { Sporadic }\end{array}$ & $\begin{array}{l}\text { Ischaemia causing } \\
\text { impaired protein folding }\end{array}$ & $\begin{array}{l}\text { Energy deficiency causing } \\
\text { ER chaperone and enzyme } \\
\text { dysfunction }\end{array}$ & $1,51,54,59,61,62$ \\
\hline Sleep apnoea & $\begin{array}{l}\text { Neuronal death } \\
\text { Sporadic. }\end{array}$ & $\begin{array}{l}\text { Ischaemia causing } \\
\text { impaired protein folding }\end{array}$ & $\begin{array}{l}\text { Energy deficiency causing } \\
\text { ER chaperone and enzyme } \\
\text { dysfunction }\end{array}$ & 45 \\
\hline Trauma & $\begin{array}{l}\text { Neuronal death } \\
\text { Sporadic }\end{array}$ & $\begin{array}{l}\text { Neuronal trauma and } \\
\text { impaired perfusion }\end{array}$ & $\begin{array}{l}\text { Incompletely understood } \\
\text { Likely involves disturbed } \\
\text { energy metabolism and ER } \\
\text { calcium homeostasis }\end{array}$ & 139 \\
\hline
\end{tabular}




\section{Table1: Neurodegenerative diseases and ER stress: an overview.}

$\mathrm{CACH}$ : Childhood ataxia with central hypomyelination; VWM: vanishing white matter; elF2: eukaryotic translation initiation factor 2; ATF4: activating transcription factor 4; PLP1: proteolipid protein 1; CHOP: CCAAT/enhancer binding protein; IRE1: Inositolrequiring enzyme-1; Bip: Binding immunoglobulin protein; PMP22: peripheral myelin protein 22; PS1: presenilin 1; ERAD: ERassociated protein degradation; SOD1: Cu/Zn superoxide dismutase enzyme; SERCA: sarco/endoplasmic reticulum Ca2+ATPase; PLP1: proteolipid protein 1; MPZ: myelin protein zero 


\section{References}

1. Nakka VP, Gusain A, Raghubir R. Endoplasmic reticulum stress plays critical role in brain damage after cerebral ischemia/reperfusion in rats. Neurotox Res. 2010; 17(2): 189-202.

2. Kaneko M, Koike H, Saito R, Kitamura Y, Okuma Y, Nomura Y. Loss of HRD1-mediated protein degradation causes amyloid precursor protein accumulation and amyloid-beta generation. J Neurosci. 2010; 30(11): 3924-32. 3. Lee JH, Won SM, Suh J, Son SJ, Moon GJ, Park UJ, et al. Induction of the unfolded protein response and cell death pathway in Alzheimer's disease, but not in aged Tg2576 mice. Exp Mol Med. 2010; 42(5): 386-94.

4. Honjo Y, Ito H, Horibe T, Takahashi R, Kawakami K. Protein disulfide isomerase-immunopositive inclusions in patients with Alzheimer disease. Brain Res. 2010; 1349: 90-6.

5. Quaglio E, Restelli E, Garofoli A, Dossena S, De Luigi A, Tagliavacca L, et al. Expression of mutant or cytosolic PrP in transgenic mice and cells is not associated with endoplasmic reticulum stress or proteasome dysfunction. PLoS ONE. 2011; 6(4): e19339.

6. Dossena S, Imeri L, Mangieri M, Garofoli A, Ferrari L, Senatore A, et al. Mutant prion protein expression causes motor and memory deficits and abnormal sleep patterns in a transgenic mouse model. Neuron. 2008; 60(4): 598-609.

7. Nunziante M, Ackermann K, Dietrich K, Wolf H, Gadtke L, Gilch S, et al. Proteasomal dysfunction and endoplasmic reticulum stress enhance trafficking of 
prion protein aggregates through the secretory pathway and increase accumulation of pathologic prion protein. J Biol Chem. 2011; 286(39): 33942-53. 8. Rane NS, Kang SW, Chakrabarti O, Feigenbaum L, Hegde RS. Reduced translocation of nascent prion protein during ER stress contributes to neurodegeneration. Dev Cell. 2008; 15(3): 359-70.

9. Moreno JA, Radford H, Peretti D, Steinert JR, Verity N, Martin MG, et al. Sustained translational repression by elF2alpha-P mediates prion neurodegeneration. Nature. 2012; 485(7399): 507-11.

10. Marciniak SJ, Ron D. Endoplasmic reticulum stress signaling in disease. Physiol Rev. 2006; 86(4): 1133-49.

11. Davies MJ, Miranda E, Roussel BD, Kaufman RJ, Marciniak SJ, Lomas DA. Neuroserpin polymers activate NF-kappaB by a calcium signalling pathway that is independent of the unfolded protein response. J Biol Chem. 2009; 284(27): 18202-9.

12. Duennwald ML, Lindquist S. Impaired ERAD and ER stress are early and specific events in polyglutamine toxicity. Genes Dev. 2008; 22(23): 3308-19.

13. Marciniak SJ, Yun CY, Oyadomari S, Novoa I, Zhang Y, Jungreis R, et al. $\mathrm{CHOP}$ induces death by promoting protein synthesis and oxidation in the stressed endoplasmic reticulum. Genes Dev. 2004; 18: 3066-77.

14. Harding $\mathrm{H}$, Zhang $\mathrm{Y}$, Ron D. Translation and protein folding are coupled by an endoplasmic reticulum resident kinase. Nature. 1999; 397(6716): 271-4.

15. Owen CR, Kumar R, Zhang P, McGrath BC, Cavener DR, Krause GS. PERK is responsible for the increased phosphorylation of elF2alpha and the 
severe inhibition of protein synthesis after transient global brain ischemia. $\mathrm{J}$ Neurochem. 2005; 94(5): 1235-42.

16. Marciniak SJ, Garcia-Bonilla L, Hu J, Harding HP, Ron D. Activationdependent substrate recruitment by the eukaryotic translation initiation factor 2 kinase PERK. J Cell Biol. 2006; 172(2): 201-9.

17. Harding $\mathrm{H}$, Zhang $\mathrm{Y}$, Zeng $\mathrm{H}$, Novoa I, Lu $\mathrm{P}$, Calfon $\mathrm{M}$, et al. An integrated stress response regulates amino acid metabolism and resistance to oxidative stress. Mol Cell. 2003; 11: 619-33.

18. Dalton LE, Healey E, Irving J, Marciniak SJ. Phosphoproteins in stressinduced disease. Prog Mol Biol TransI Sci. 2012; 106: 189-221.

19. Harding HP, Zhang Y, Zeng H, Novoa I, Lu PD, Calfon M, et al. An integrated stress response regulates amino acid metabolism and resistance to oxidative stress. Mol Cell. 2003; 11(3): 619-33.

20. Hao S, Sharp JW, Ross-Inta CM, McDaniel BJ, Anthony TG, Wek RC, et al. Uncharged tRNA and sensing of amino acid deficiency in mammalian piriform cortex. Science. 2005; 307(5716): 1776-8.

21. Maurin AC, Jousse C, Averous J, Parry L, Bruhat A, Cherasse Y, et al. The GCN2 kinase biases feeding behavior to maintain amino acid homeostasis in omnivores. Cell Metab. 2005; 1(4): 273-7.

22. Kantor L, Harding HP, Ron D, Schiffmann R, Kaneski CR, Kimball SR, et al. Heightened stress response in primary fibroblasts expressing mutant elF2B genes from $\mathrm{CACH} / \mathrm{VWM}$ leukodystrophy patients. Hum Genet. 2005; 118(1): 99106. 
23. Leegwater PA, Vermeulen G, Konst AA, Naidu S, Mulders J, Visser A, et al. Subunits of the translation initiation factor elF2B are mutant in leukoencephalopathy with vanishing white matter. Nat Genet. 2001; 29(4): 383-8. 24. Richardson JP, Mohammad SS, Pavitt GD. Mutations causing childhood ataxia with central nervous system hypomyelination reduce eukaryotic initiation factor 2B complex formation and activity. Mol Cell Biol. 2004; 24(6): 2352-63. 25. Harding HP, Calfon M, Urano F, Novoa I, Ron D. Transcriptional and translational control in the mammalian unfolded protein response. Annu Rev Cell Dev Biol. 2002; 18: 575-99.

26. Southwood CM, Garbern J, Jiang W, Gow A. The unfolded protein response modulates disease severity in Pelizaeus-Mezbacher Disease. Neuron. 2002; 36: 585-96.

27. Pennuto M, Tinelli E, Malaguti M, Del Carro U, D'Antonio M, Ron D, et al. Ablation of the UPR-mediator CHOP restores motor function and reduces demyelination in Charcot-Marie-Tooth 1B mice. Neuron. 2008; 57(3): 393-405.

28. Boyce M, Bryant KF, Jousse C, Long K, Harding HP, Scheuner D, et al. A Selective inhibitor of elF2a dephosphorylation protects cells from ER stress. Science. 2005; 307: 935-9.

29. Tsaytler P, Harding HP, Ron D, Bertolotti A. Selective inhibition of a regulatory subunit of protein phosphatase 1 restores proteostasis. Science. 2011; 332(6025): 91-4. 
30. Kondo S, Murakami T, Tatsumi K, Ogata M, Kanemoto S, Otori K, et al. OASIS, a CREB/ATF-family member, modulates UPR signalling in astrocytes. Nat Cell Biol. 2005; 7(2): 186-94.

31. Calfon M, Zeng H, Urano F, Till JH, Hubbard SR, Harding HP, et al. IRE1 couples endoplasmic reticulum load to secretory capacity by processing the XBP-1 mRNA. Nature. 2002; 415: 92-6.

32. Hosoi T, Ogawa K, Ozawa K. Homocysteine induces X-box-binding protein 1 splicing in the mice brain. Neurochem Int. 2010; 56(2): 216-20.

33. Meusser B, Hirsch C, Jarosch E, Sommer T. ERAD: the long road to destruction. Nat Cell Biol. 2005; 7(8): 766-72.

34. Haynes CM, Titus EA, Cooper AA. Degradation of misfolded proteins prevents ER-derived oxidative stress and cell death. Mol Cell. 2004; 15(5): 76776.

35. Yoshida H, Matsui T, Hosokawa N, Kaufman RJ, Nagata K, Mori K. A time-dependent phase shift in the Mammalian unfolded protein response. Dev Cell. 2003; 4(2): 265-71.

36. Rissanen A, Sivenius J, Jolkkonen J. Prolonged bihemispheric alterations in unfolded protein response related gene expression after experimental stroke. Brain Res. 2006; 1087(1): 60-6.

37. Morimoto N, Oida Y, Shimazawa M, Miura M, Kudo T, Imaizumi K, et al. Involvement of endoplasmic reticulum stress after middle cerebral artery occlusion in mice. Neuroscience. 2007; 147(4): 957-67. 
38. Hayashi T, Hamakawa K, Nagotani S, Jin G, Li F, Deguchi K, et al. HMG CoA reductase inhibitors reduce ischemic brain injury of Wistar rats through decreasing oxidative stress on neurons. Brain Res. 2005; 1037(1-2): 52-8. 39. Szydlowska K, Tymianski M. Calcium, ischemia and excitotoxicity. Cell Calcium. 2010; 47(2): 122-9.

40. Coe H, Michalak M. Calcium binding chaperones of the endoplasmic reticulum. Gen Physiol Biophys. 2009; 28 Spec No Focus: F96-F103.

41. Nguyen HN, Wang C, Perry DC. Depletion of intracellular calcium stores is toxic to SH-SY5Y neuronal cells. Brain Res. 2002; 924(2): 159-66.

42. Zhang F, Liu CL, Hu BR. Irreversible aggregation of protein synthesis machinery after focal brain ischemia. J Neurochem. 2006; 98(1): 102-12.

43. Althausen S, Mengesdorf T, Mies G, Olah L, Nairn AC, Proud CG, et al. Changes in the phosphorylation of initiation factor elF-2alpha, elongation factor eEF-2 and p70 S6 kinase after transient focal cerebral ischaemia in mice. J Neurochem. 2001; 78(4): 779-87.

44. Qi X, Okuma Y, Hosoi T, Nomura Y. Edaravone protects against hypoxia/ischemia-induced endoplasmic reticulum dysfunction. J Pharmacol Exp Ther. 2004; 311(1): 388-93.

45. Zhu Y, Fenik P, Zhan G, Sanfillipo-Cohn B, Naidoo N, Veasey SC. Eif-2a protects brainstem motoneurons in a murine model of sleep apnea. J Neurosci. 2008; 28(9): 2168-78. 
46. Shibata M, Hattori H, Sasaki T, Gotoh J, Hamada J, Fukuuchi Y.

Activation of caspase-12 by endoplasmic reticulum stress induced by transient middle cerebral artery occlusion in mice. Neuroscience. 2003; 118(2): 491-9.

47. Xue Y, Daly A, Yngvadottir B, Liu M, Coop G, Kim Y, et al. Spread of an inactive form of caspase-12 in humans is due to recent positive selection. Am J Hum Genet. 2006; 78(4): 659-70.

48. Hitomi J, Katayama T, Eguchi Y, Kudo T, Taniguchi M, Koyama Y, et al. Involvement of caspase-4 in endoplasmic reticulum stress-induced apoptosis and Abeta-induced cell death. J Cell Biol. 2004; 165(3): 347-56.

49. Kumar R, Krause GS, Yoshida H, Mori K, DeGracia DJ. Dysfunction of the unfolded protein response during global brain ischemia and reperfusion. J Cereb Blood Flow Metab. 2003; 23(4): 462-71.

50. Chihara K, Saito A, Murakami T, Hino S, Aoki Y, Sekiya H, et al. Increased vulnerability of hippocampal pyramidal neurons to the toxicity of kainic acid in OASIS-deficient mice. J Neurochem. 2009; 110(3): 956-65.

51. Osada N, Kosuge Y, Kihara T, Ishige K, Ito Y. Apolipoprotein E-deficient mice are more vulnerable to ER stress after transient forebrain ischemia. Neurochem Int. 2009; 54(7): 403-9.

52. Tajiri S, Oyadomari S, Yano S, Morioka M, Gotoh T, Hamada JI, et al. Ischemia-induced neuronal cell death is mediated by the endoplasmic reticulum stress pathway involving CHOP. Cell Death Differ. 2004; 11(4): 403-15.

53. Hayashi T, Saito A, Okuno S, Ferrand-Drake M, Dodd RL, Chan PH. Damage to the endoplasmic reticulum and activation of apoptotic machinery by 
oxidative stress in ischemic neurons. J Cereb Blood Flow Metab. 2005; 25(1): 41-53.

54. Oida Y, Shimazawa M, Imaizumi K, Hara H. Involvement of endoplasmic reticulum stress in the neuronal death induced by transient forebrain ischemia in gerbil. Neuroscience. 2008; 151(1): 111-9.

55. Benavides A, Pastor D, Santos P, Tranque P, Calvo S. CHOP plays a pivotal role in the astrocyte death induced by oxygen and glucose deprivation. Glia. 2005; 52(4): 261-75.

56. Paschen W, Hayashi T, Saito A, Chan PH. GADD34 protein levels increase after transient ischemia in the cortex but not in the CA1 subfield: implications for post-ischemic recovery of protein synthesis in ischemia-resistant cells. J Neurochem. 2004; 90(3): 694-701.

57. McCaig D, Imai H, Gallagher L, Graham DI, Harland J, Moira Brown S, et al. Evolution of GADD34 expression after focal cerebral ischaemia. Brain Res. 2005; 1034(1-2): 51-61.

58. Sokka AL, Putkonen N, Mudo G, Pryazhnikov E, Reijonen S, Khiroug L, et al. Endoplasmic reticulum stress inhibition protects against excitotoxic neuronal injury in the rat brain. J Neurosci. 2007; 27(4): 901-8.

59. Osada N, Kosuge Y, Ishige K, Ito Y. Characterization of neuronal and astroglial responses to ER stress in the hippocampal CA1 area in mice following transient forebrain ischemia. Neurochem Int. 2010; 57(1): 1-7.

60. Yu Z, Luo H, Fu W, Mattson MP. The endoplasmic reticulum stressresponsive protein GRP78 protects neurons against excitotoxicity and apoptosis: 
suppression of oxidative stress and stabilization of calcium homeostasis. Exp Neurol. 1999; 155(2): 302-14.

61. Ouyang YB, Xu LJ, Emery JF, Lee AS, Giffard RG. Overexpressing GRP78 influences Ca2+ handling and function of mitochondria in astrocytes after ischemia-like stress. Mitochondrion. 2011; 11(2): 279-86.

62. Kudo T, Kanemoto S, Hara H, Morimoto N, Morihara T, Kimura R, et al. A molecular chaperone inducer protects neurons from ER stress. Cell Death Differ. 2008; 15(2): 364-75.

63. Tamatani M, Matsuyama T, Yamaguchi A, Mitsuda N, Tsukamoto Y, Taniguchi M, et al. ORP150 protects against hypoxia/ischemia-induced neuronal death. Nature medicine. 2001; 7(3): 317-23.

64. Zhao L, Longo-Guess C, Harris BS, Lee JW, Ackerman SL. Protein accumulation and neurodegeneration in the woozy mutant mouse is caused by disruption of SIL1, a cochaperone of BiP. Nat Genet. 2005; 37(9): 974-9.

65. Zhao L, Rosales C, Seburn K, Ron D, Ackerman SL. Alteration of the unfolded protein response modifies neurodegeneration in a mouse model of Marinesco-Sjogren syndrome. Hum Mol Genet. 2010; 19(1): 25-35.

66. Luheshi LM, Tartaglia GG, Brorsson AC, Pawar AP, Watson IE, Chiti F, et al. Systematic in vivo analysis of the intrinsic determinants of amyloid Beta pathogenicity. PLoS Biol. 2007; 5(11): e290.

67. Katayama T, Imaizumi K, Sato N, Miyoshi K, Kudo T, Hitomi J, et al. Presenilin-1 mutations downregulate the signalling pathway of the unfoldedprotein response. Nat Cell Biol. 1999; 1(8): 479-85. 
68. Hoozemans JJ, Veerhuis R, Van Haastert ES, Rozemuller JM, Baas F, Eikelenboom $\mathrm{P}$, et al. The unfolded protein response is activated in Alzheimer's disease. Acta Neuropathol. 2005; 110(2): 165-72.

69. Hoozemans JJ, Stieler J, van Haastert ES, Veerhuis R, Rozemuller AJ, Baas $F$, et al. The unfolded protein response affects neuronal cell cycle protein expression: implications for Alzheimer's disease pathogenesis. Exp Gerontol. 2006; 41(4): 380-6.

70. Unterberger U, Hoftberger R, Gelpi E, Flicker H, Budka H, Voigtlander T. Endoplasmic reticulum stress features are prominent in Alzheimer disease but not in prion diseases in vivo. J Neuropathol Exp Neurol. 2006; 65(4): 348-57. 71. Hoozemans JJ, van Haastert ES, Nijholt DA, Rozemuller AJ, Eikelenboom $\mathrm{P}$, Scheper $\mathrm{W}$. The unfolded protein response is activated in pretangle neurons in Alzheimer's disease hippocampus. Am J Pathol. 2009; 174(4): 1241-51. 72. Resende R, Ferreiro E, Pereira C, Oliveira CR. ER stress is involved in Abeta-induced GSK-3beta activation and tau phosphorylation. J Neurosci Res. 2008; 86(9): 2091-9.

73. Lee do Y, Lee KS, Lee HJ, Kim do H, Noh YH, Yu K, et al. Activation of PERK signaling attenuates Abeta-mediated ER stress. PLoS ONE. 2010; 5(5): e10489.

74. Seyb KI, Ansar S, Bean J, Michaelis ML. beta-Amyloid and endoplasmic reticulum stress responses in primary neurons: effects of drugs that interact with the cytoskeleton. J Mol Neurosci. 2006; 28(2): 111-23. 
75. Song S, Lee H, Kam TI, Tai ML, Lee JY, Noh JY, et al. E2-25K/Hip-2 regulates caspase-12 in ER stress-mediated Abeta neurotoxicity. J Cell Biol. 2008; 182(4): 675-84.

76. Ghribi O, Herman MM, DeWitt DA, Forbes MS, Savory J. Abeta(1-42) and aluminum induce stress in the endoplasmic reticulum in rabbit hippocampus, involving nuclear translocation of gadd 153 and NF-kappaB. Brain Res Mol Brain Res. 2001; 96(1-2): 30-8.

77. Schapansky J, Olson K, Van Der Ploeg R, Glazner G. NF-kappaB activated by ER calcium release inhibits Abeta-mediated expression of $\mathrm{CHOP}$ protein: enhancement by AD-linked mutant presenilin 1. Exp Neurol. 2007; 208(2): 169-76.

78. Casas-Tinto S, Zhang Y, Sanchez-Garcia J, Gomez-Velazquez M, Rincon-Limas DE, Fernandez-Funez P. The ER stress factor XBP1s prevents amyloid-beta neurotoxicity. Hum Mol Genet. 2011; 20(11): 2144-60.

79. Milhavet O, Martindale JL, Camandola S, Chan SL, Gary DS, Cheng A, et al. Involvement of Gadd153 in the pathogenic action of presenilin-1 mutations. J Neurochem. 2002; 83(3): 673-81.

80. Jin H, Sanjo N, Uchihara T, Watabe K, St George-Hyslop P, Fraser PE, et al. Presenilin-1 holoprotein is an interacting partner of sarco endoplasmic reticulum calcium-ATPase and confers resistance to endoplasmic reticulum stress. J Alzheimers Dis. 2010; 20(1): 261-73.

81. Stutzmann GE, Mattson MP. Endoplasmic reticulum $\mathrm{Ca}(2+)$ handling in excitable cells in health and disease. Pharmacol Rev. 2011; 63(3): 700-27. 
82. Bezprozvanny I, Mattson MP. Neuronal calcium mishandling and the pathogenesis of Alzheimer's disease. Trends Neurosci. 2008; 31(9): 454-63.

83. O'Connor T, Sadleir KR, Maus E, Velliquette RA, Zhao J, Cole SL, et al. Phosphorylation of the translation initiation factor elF2alpha increases BACE1 levels and promotes amyloidogenesis. Neuron. 2008; 60(6): 988-1009.

84. Kudo T, Okumura M, Imaizumi K, Araki W, Morihara T, Tanimukai H, et al. Altered localization of amyloid precursor protein under endoplasmic reticulum stress. Biochem Biophys Res Commun. 2006; 344(2): 525-30.

85. Saltini G, Dominici R, Lovati C, Cattaneo M, Michelini S, Malferrari G, et al. A novel polymorphism in SEL1L confers susceptibility to Alzheimer's disease. Neurosci Lett. 2006; 398(1-2): 53-8.

86. Bauereis B, Haskins WE, Lebaron RG, Renthal R. Proteomic insights into the protective mechanisms of an in vitro oxidative stress model of early stage Parkinson's disease. Neurosci Lett. 2011; 488(1): 11-6.

87. Sado M, Yamasaki Y, Iwanaga T, Onaka Y, Ibuki T, Nishihara S, et al. Protective effect against Parkinson's disease-related insults through the activation of XBP1. Brain Res. 2009; 1257: 16-24.

88. Egawa N, Yamamoto K, Inoue H, Hikawa R, Nishi K, Mori K, et al. The endoplasmic reticulum stress sensor, ATF6alpha, protects against neurotoxininduced dopaminergic neuronal death. J Biol Chem. 2011; 286(10): 7947-57. 89. Chigurupati S, Wei Z, Belal C, Vandermey M, Kyriazis GA, Arumugam TV, et al. The homocysteine-inducible endoplasmic reticulum stress protein counteracts calcium store depletion and induction of CCAAT enhancer-binding 
protein homologous protein in a neurotoxin model of Parkinson disease. J Biol Chem. 2009; 284(27): 18323-33.

90. Silva RM, Ries V, Oo TF, Yarygina O, Jackson-Lewis V, Ryu EJ, et al. CHOP/GADD153 is a mediator of apoptotic death in substantia nigra dopamine neurons in an in vivo neurotoxin model of parkinsonism. J Neurochem. 2005; 95(4): 974-86.

91. Dukes AA, Van Laar VS, Cascio M, Hastings TG. Changes in endoplasmic reticulum stress proteins and aldolase $A$ in cells exposed to dopamine. J Neurochem. 2008; 106(1): 333-46.

92. Hoozemans JJ, van Haastert ES, Eikelenboom P, de Vos RA, Rozemuller JM, Scheper W. Activation of the unfolded protein response in Parkinson's disease. Biochem Biophys Res Commun. 2007; 354(3): 707-11.

93. Silva RM, Ries V, Oo TF, Yarygina O, Jackson-Lewis V, Ryu EJ, et al. CHOP/GADD153 is a mediator of apoptotic death in substantia nigra dopamine neurons in an in vivo neurotoxin model of parkinsonism. J Neurochem. 2005; 95(4): 974-86.

94. Kitada T, Asakawa S, Hattori N, Matsumine H, Yamamura Y, Minoshima $\mathrm{S}$, et al. Mutations in the parkin gene cause autosomal recessive juvenile parkinsonism. Nature. 1998; 392(6676): 605-8.

95. Shimura H, Hattori N, Kubo S, Mizuno Y, Asakawa S, Minoshima S, et al. Familial Parkinson disease gene product, parkin, is a ubiquitin-protein ligase. Nat Genet. 2000; 25(3): 302-5. 
96. Bouman L, Schlierf A, Lutz AK, Shan J, Deinlein A, Kast J, et al. Parkin is transcriptionally regulated by ATF4: evidence for an interconnection between mitochondrial stress and ER stress. Cell Death Differ. 2011; 18(5): 769-82.

97. Narendra D, Tanaka A, Suen DF, Youle RJ. Parkin is recruited selectively to impaired mitochondria and promotes their autophagy. J Cell Biol. 2008; 183(5): 795-803.

98. Shimura H, Schlossmacher MG, Hattori N, Frosch MP, Trockenbacher A, Schneider R, et al. Ubiquitination of a New Form of a-Synuclein by Parkin from Human Brain: Implications for Parkinson's Disease. Science. 2001; 28: 28.

99. Kruger R, Kuhn W, Muller T, Woitalla D, Graeber M, Kosel S, et al. Ala30Pro mutation in the gene encoding alpha-synuclein in Parkinson's disease. Nat Genet. 1998; 18(2): 106-8.

100. Smith WW, Jiang H, Pei Z, Tanaka Y, Morita H, Sawa A, et al. Endoplasmic reticulum stress and mitochondrial cell death pathways mediate A53T mutant alpha-synuclein-induced toxicity. Hum Mol Genet. 2005; 14(24): 3801-11.

101. Bellucci A, Navarria L, Zaltieri M, Falarti E, Bodei S, Sigala S, et al. Induction of the unfolded protein response by alpha-synuclein in experimental models of Parkinson's disease. J Neurochem. 2011; 116(4): 588-605. 102. Colla E, Coune P, Liu Y, Pletnikova O, Troncoso JC, Iwatsubo T, et al. Endoplasmic reticulum stress is important for the manifestations of alphasynucleinopathy in vivo. J Neurosci. 2012; 32(10): 3306-20. 
103. Inden M, Kitamura $\mathrm{Y}$, Takeuchi $\mathrm{H}$, Yanagida $\mathrm{T}$, Takata K, Kobayashi $\mathrm{Y}$, et al. Neurodegeneration of mouse nigrostriatal dopaminergic system induced by repeated oral administration of rotenone is prevented by 4-phenylbutyrate, a chemical chaperone. J Neurochem. 2007; 101(6): 1491-504.

104. Hara H, Kamiya T, Adachi T. Endoplasmic reticulum stress inducers provide protection against 6-hydroxydopamine-induced cytotoxicity. Neurochem Int. 2011; 58(1): 35-43.

105. Carnemolla A, Fossale E, Agostoni E, Michelazzi S, Calligaris R, De Maso L, et al. Rrs1 is involved in endoplasmic reticulum stress response in Huntington disease. J Biol Chem. 2009; 284(27): 18167-73.

106. Lajoie $\mathrm{P}$, Snapp EL. Changes in BiP availability reveal hypersensitivity to acute endoplasmic reticulum stress in cells expressing mutant huntingtin. J Cell Sci. 2011; 124(Pt 19): 3332-43.

107. Bennett EJ, Shaler TA, Woodman B, Ryu KY, Zaitseva TS, Becker CH, et al. Global changes to the ubiquitin system in Huntington's disease. Nature. 2007; 448(7154): 704-8.

108. Higo T, Hamada K, Hisatsune C, Nukina N, Hashikawa T, Hattori M, et al. Mechanism of ER stress-induced brain damage by IP(3) receptor. Neuron. 2010; 68(5): 865-78.

109. Sasaki S. Endoplasmic reticulum stress in motor neurons of the spinal cord in sporadic amyotrophic lateral sclerosis. J Neuropathol Exp Neurol. 2010; 69(4): 346-55. 
110. Urushitani M, Sik A, Sakurai T, Nukina N, Takahashi R, Julien JP. Chromogranin-mediated secretion of mutant superoxide dismutase proteins linked to amyotrophic lateral sclerosis. Nat Neurosci. 2006; 9(1): 108-18.

111. Kikuchi H, Almer G, Yamashita S, Guegan C, Nagai M, Xu Z, et al. Spinal cord endoplasmic reticulum stress associated with a microsomal accumulation of mutant superoxide dismutase-1 in an ALS model. Proc Natl Acad Sci U S A. 2006; 103(15): 6025-30.

112. Kieran D, Woods I, Villunger A, Strasser A, Prehn JH. Deletion of the BH3-only protein puma protects motoneurons from ER stress-induced apoptosis and delays motoneuron loss in ALS mice. Proc Natl Acad Sci U S A. 2007; 104(51): 20606-11.

113. Walker AK, Farg MA, Bye CR, McLean CA, Horne MK, Atkin JD. Protein disulphide isomerase protects against protein aggregation and is S-nitrosylated in amyotrophic lateral sclerosis. Brain. 2010; 133(Pt 1): 105-16.

114. Nagata $\mathrm{T}$, llieva $\mathrm{H}$, Murakami $\mathrm{T}$, Shiote $\mathrm{M}$, Narai $\mathrm{H}$, Ohta $\mathrm{Y}$, et al. Increased ER stress during motor neuron degeneration in a transgenic mouse model of amyotrophic lateral sclerosis. Neurol Res. 2007; 29(8): 767-71.

115. Saxena S, Cabuy E, Caroni P. A role for motoneuron subtype-selective ER stress in disease manifestations of FALS mice. Nat Neurosci. 2009; 12(5): 627-36.

116. Wang L, Popko B, Roos RP. The unfolded protein response in familial amyotrophic lateral sclerosis. Hum Mol Genet. 2011; 20(5): 1008-15. 
117. Hetz C, Thielen P, Matus S, Nassif M, Court F, Kiffin R, et al. XBP-1 deficiency in the nervous system protects against amyotrophic lateral sclerosis by increasing autophagy. Genes Dev. 2009; 23(19): 2294-306.

118. Mori A, Yamashita S, Uchino K, Suga T, Ikeda T, Takamatsu K, et al. Derlin-1 overexpression ameliorates mutant SOD1-induced endoplasmic reticulum stress by reducing mutant SOD1 accumulation. Neurochem Int. 2011; 58(3): 344-53.

119. Nishitoh $\mathrm{H}$, Kadowaki $\mathrm{H}$, Nagai A, Maruyama T, Yokota T, Fukutomi H, et al. ALS-linked mutant SOD1 induces ER stress- and ASK1-dependent motor neuron death by targeting Derlin-1. Genes Dev. 2008; 22(11): 1451-64. 120. Lin W, Bailey SL, Ho H, Harding HP, Ron D, Miller SD, et al. The integrated stress response prevents demyelination by protecting oligodendrocytes against immune-mediated damage. J Clin Invest. 2007; 117(2): 448-56.

121. Lin W, Kemper A, Dupree JL, Harding HP, Ron D, Popko B. Interferongamma inhibits central nervous system remyelination through a process modulated by endoplasmic reticulum stress. Brain. 2006; 129(Pt 5): 1306-18. 122. Davis RL, Shrimpton AE, Holohan PD, Bradshaw C, Feiglin D, Collins GH, et al. Familial dementia caused by polymerization of mutant neuroserpin. Nature. 1999; 401(6751): 376-9.

123. Miranda E, MacLeod I, Davies MJ, Perez J, Romisch K, Crowther DC, et al. The intracellular accumulation of polymeric neuroserpin explains the severity of the dementia FENIB. Hum Mol Genet. 2008; 17(11): 1527-39. 
124. Kroeger H, Miranda E, MacLeod I, Perez J, Crowther DC, Marciniak SJ, et al. Endoplasmic reticulum-associated degradation (ERAD) and autophagy cooperate to degrade polymerogenic mutant serpins. J Biol Chem. 2009; 284(34): 22793-802.

125. Pahl HL, Baeuerle PA. The ER-overload response: activation of NF-kappa B. Trends Biochem Sci. 1997; 22(2): 63-7.

126. Hidvegi T, Ewing M, Hale P, Dippold C, Beckett C, Kemp C, et al. An autophagy-enhancing drug promotes degradation of mutant alpha1-antitrypsin Z and reduces hepatic fibrosis. Science. 2010; 329(5988): 229-32.

127. Chen X, Wu J, Lvovskaya S, Herndon E, Supnet C, Bezprozvanny I. Dantrolene is neuroprotective in Huntington's disease transgenic mouse model. Mol Neurodegener. 2011; 6: 81.

128. Li F, Hayashi T, Jin G, Deguchi K, Nagotani S, Nagano I, et al. The protective effect of dantrolene on ischemic neuronal cell death is associated with reduced expression of endoplasmic reticulum stress markers. Brain Res. 2005; 1048(1-2): 59-68.

129. Jiang P, Gan M, Ebrahim AS, Lin WL, Melrose HL, Yen SH. ER stress response plays an important role in aggregation of alpha-synuclein. Mol Neurodegener. 2010; 5: 56.

130. Reijonen S, Putkonen N, Norremolle A, Lindholm D, Korhonen L. Inhibition of endoplasmic reticulum stress counteracts neuronal cell death and protein aggregation caused by N-terminal mutant huntingtin proteins. Exp Cell Res. 2008; 314(5): 950-60. 
131. Yamamoto K, Tashiro E, Imoto M. Quinotrierixin inhibited ER stressinduced XBP1 mRNA splicing through inhibition of protein synthesis. Biosci Biotechnol Biochem. 2011; 75(2): 284-8.

132. Cross BC, Bond PJ, Sadowski PG, Jha BK, Zak J, Goodman JM, et al. The molecular basis for selective inhibition of unconventional mRNA splicing by an IRE1-binding small molecule. Proc Natl Acad Sci U S A. 2012; 109(15): E86978.

133. D'Urso D, Prior R, Greiner-Petter R, Gabreels-Festen AA, Muller HW. Overloaded endoplasmic reticulum-Golgi compartments, a possible pathomechanism of peripheral neuropathies caused by mutations of the peripheral myelin protein PMP22. J Neurosci. 1998; 18(2): 731-40.

134. Kang YJ, Lu MK, Guan KL. The TSC1 and TSC2 tumor suppressors are required for proper ER stress response and protect cells from ER stress-induced apoptosis. Cell Death Differ. 2011; 18(1): 133-44.

135. Liu G, Guo H, Guo C, Zhao S, Gong D, Zhao Y. Involvement of IRE1alpha signaling in the hippocampus in patients with mesial temporal lobe epilepsy. Brain Res Bull. 2011; 84(1): 94-102.

136. Fonseca SG, Ishigaki S, Oslowski CM, Lu S, Lipson KL, Ghosh R, et al. Wolfram syndrome 1 gene negatively regulates ER stress signaling in rodent and human cells. J Clin Invest. 2010; 120(3): 744-55.

137. Chen P, Burdette AJ, Porter JC, Ricketts JC, Fox SA, Nery FC, et al. The early-onset torsion dystonia-associated protein, torsinA, is a homeostatic 
regulator of endoplasmic reticulum stress response. Hum Mol Genet. 2010; 19(18): 3502-15.

138. Wang F, Agnello G, Sotolongo N, Segatori L. Ca2+ homeostasis modulation enhances the amenability of L444P glucosylcerebrosidase to proteostasis regulation in patient-derived fibroblasts. ACS Chem Biol. 2011; 6(2): $158-68$.

139. Penas C, Verdu E, Asensio-Pinilla E, Guzman-Lenis MS, HerrandoGrabulosa M, Navarro X, et al. Valproate reduces CHOP levels and preserves oligodendrocytes and axons after spinal cord injury. Neuroscience. 2011; 178: 33-44. 
Benoit D. Roussel

$P h D$

Tel: $\quad+441223762818$ (secretary)

Fax: $\quad+441223748178$

E-mail: bdr24@cam.ac.uk

\author{
UNIVERSITY OF \\ CAMBRIDGE \\ Cambridge Institute for Medical Research \\ Wellcome Trust/MRC Building \\ Hills Road \\ Cambridge CB2 0XY \\ United Kingdom
}

\section{Dear Dr Craven}

Thank you for offering us the possibility to publish our manuscript. Please find here our revised manuscript with the editorial changes you suggested: we have included a contributions and conflicts of interest section under the same heading, there is now a panel to detail our searches on Pubmed, and there is only one qualification for each author.

Best regards

Dr BD Roussel. 

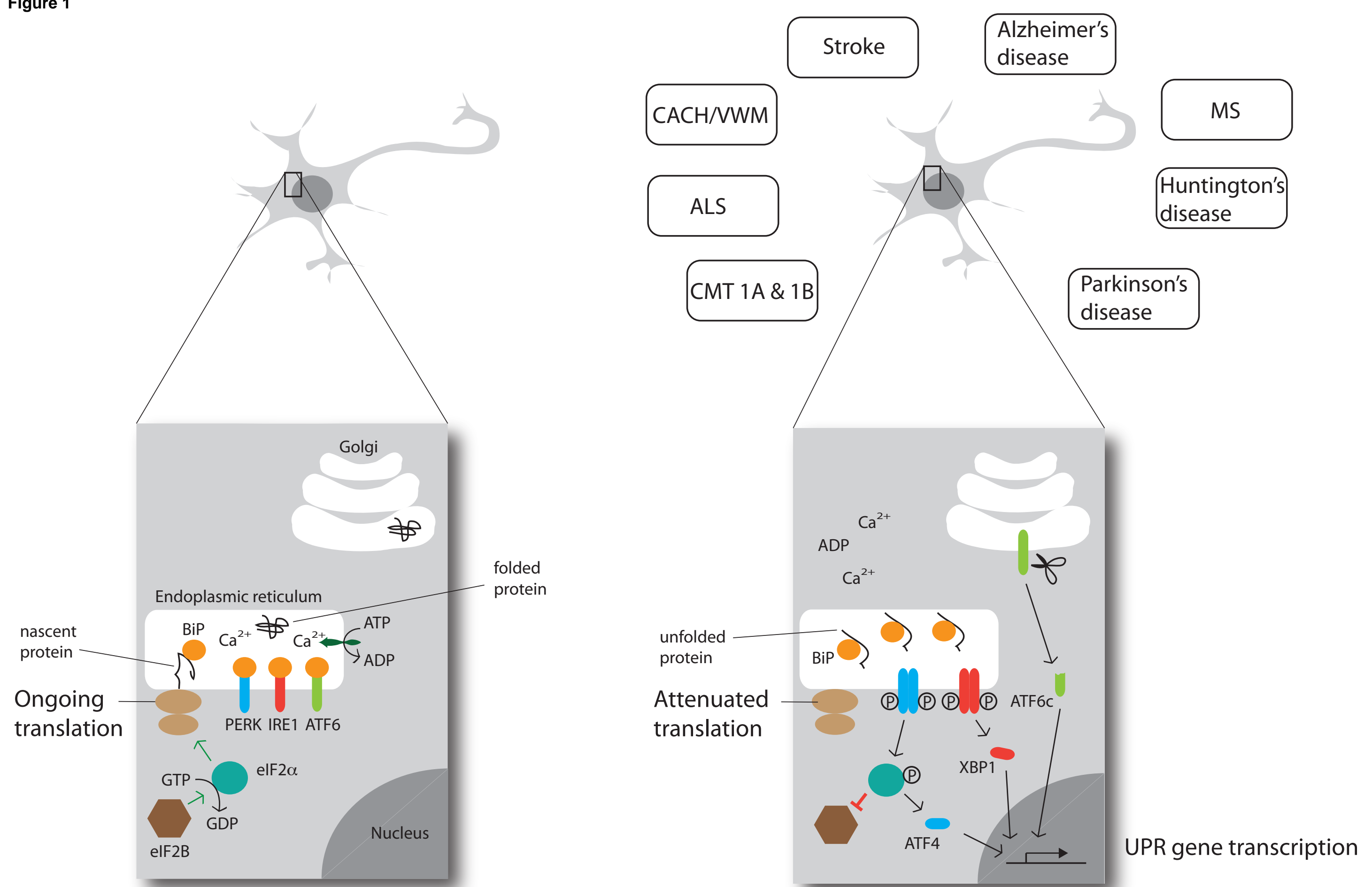
Figure 2

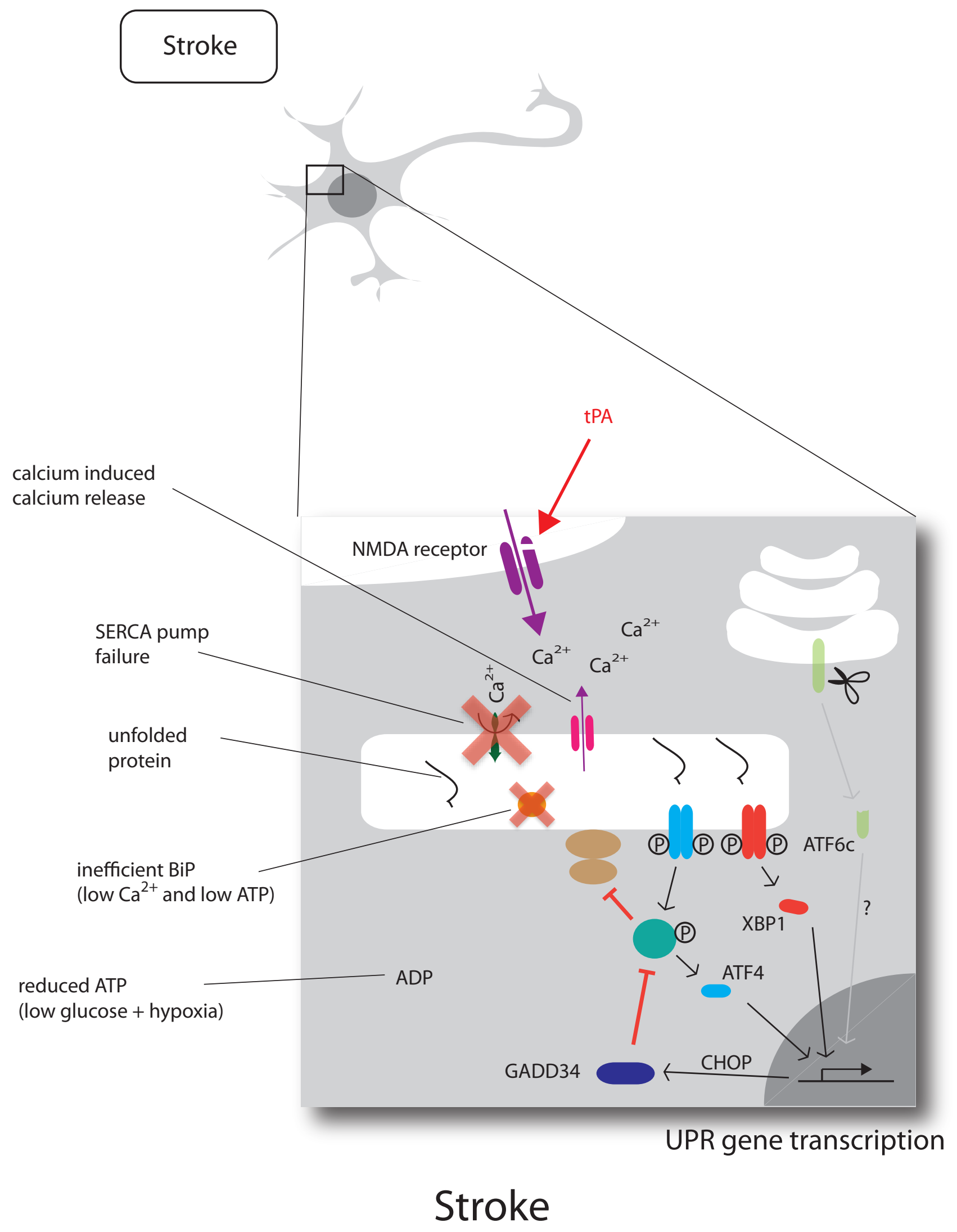


A

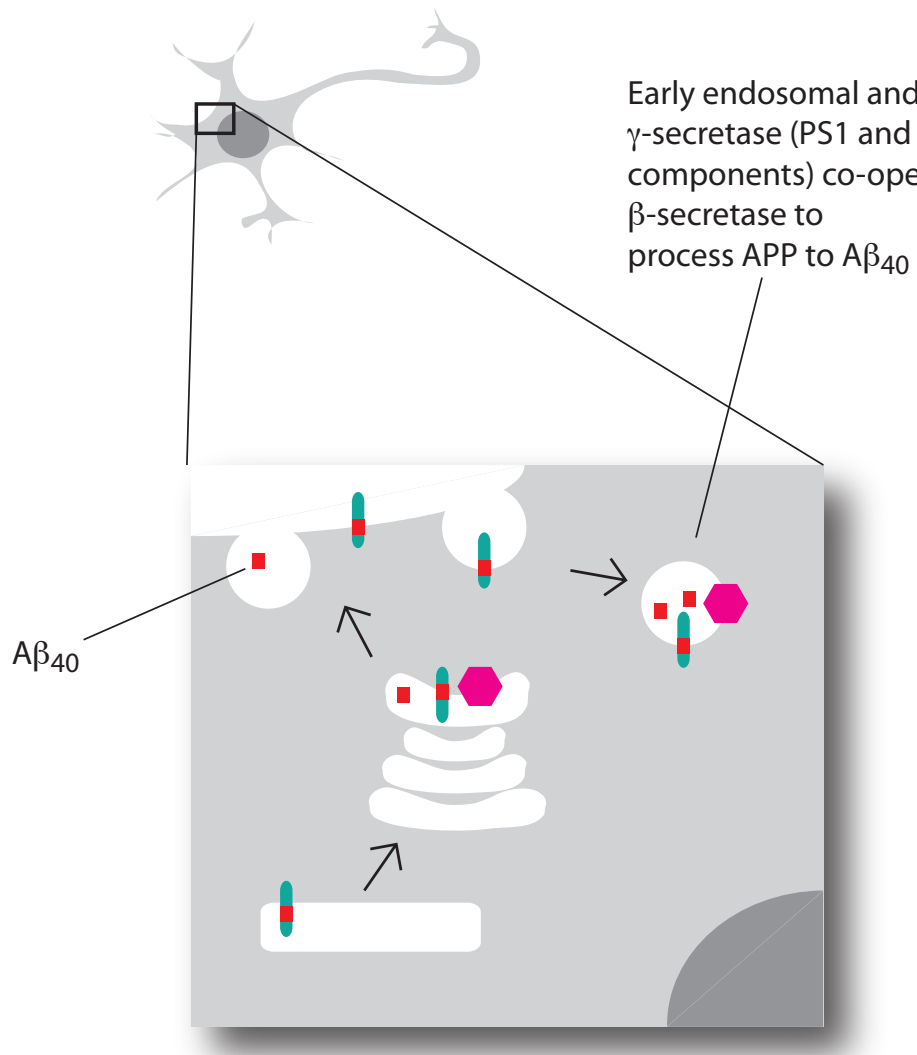

B

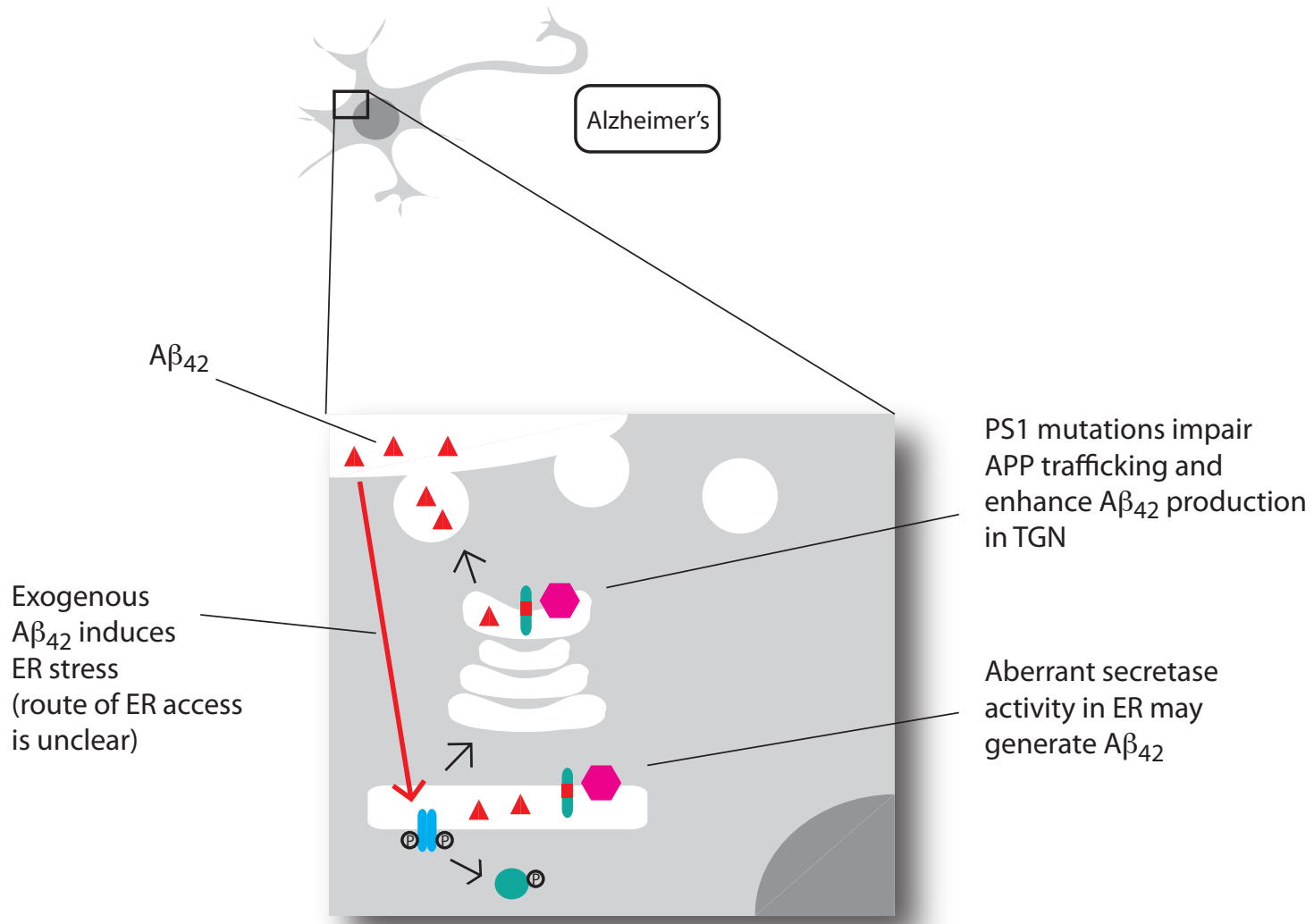

Health
- $\quad A \beta_{40}$

$\triangle \quad A \beta_{42}$

APP

Secretase

\section{Alzheimer's disease}




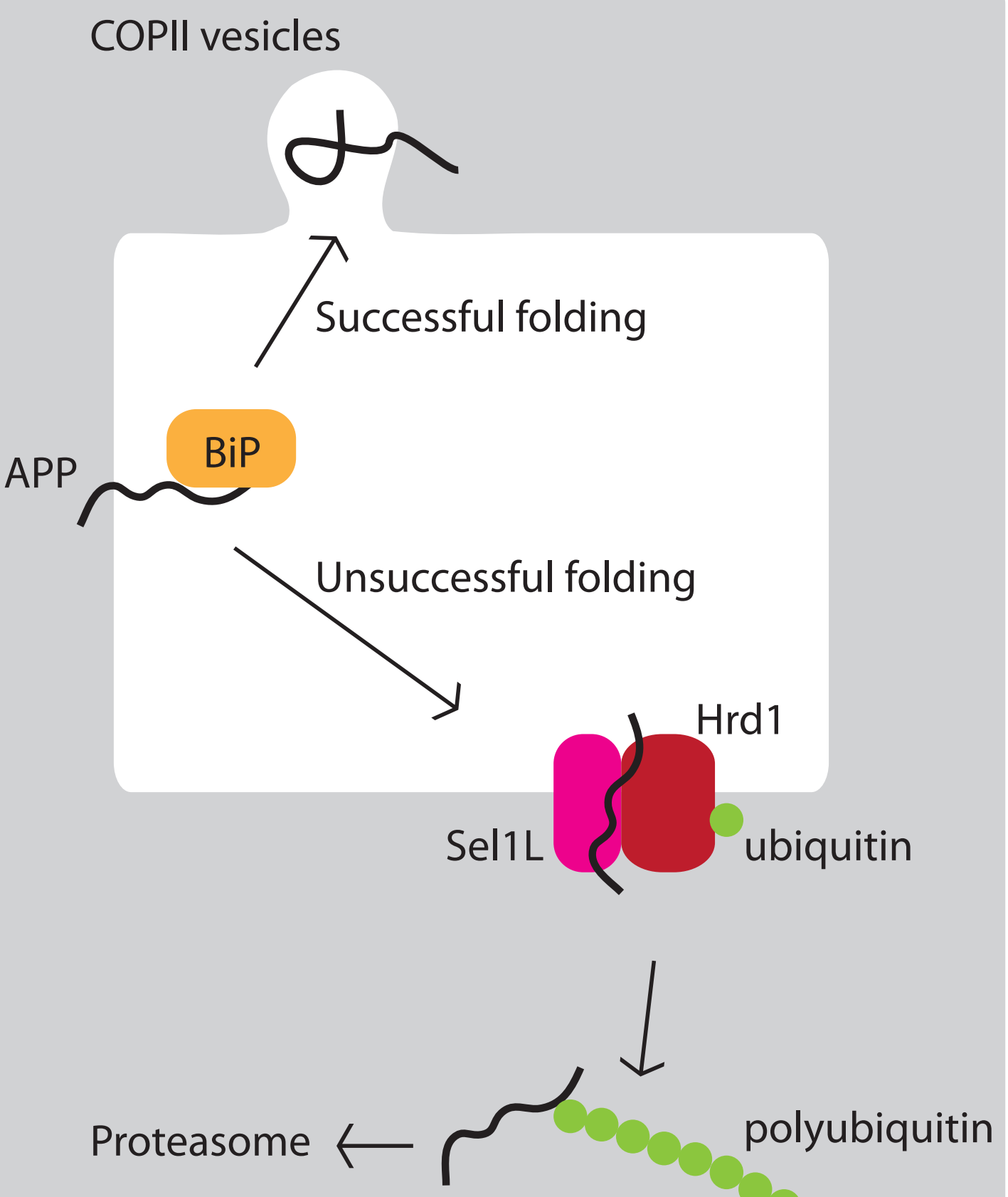


A
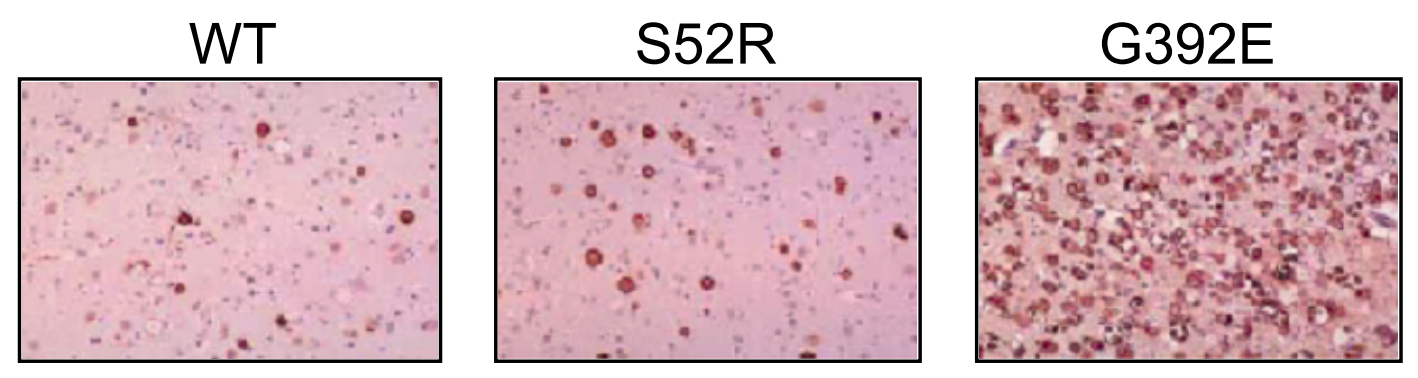

B
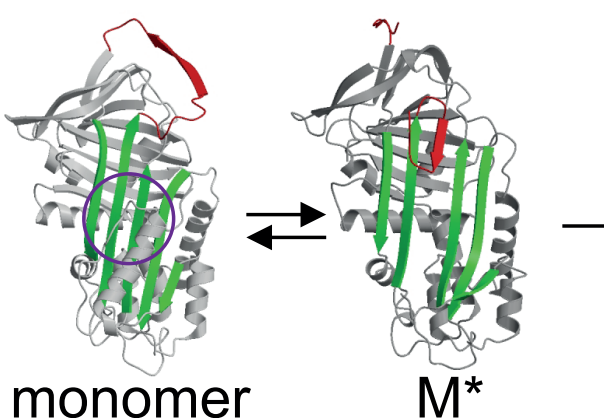

$M^{*}$

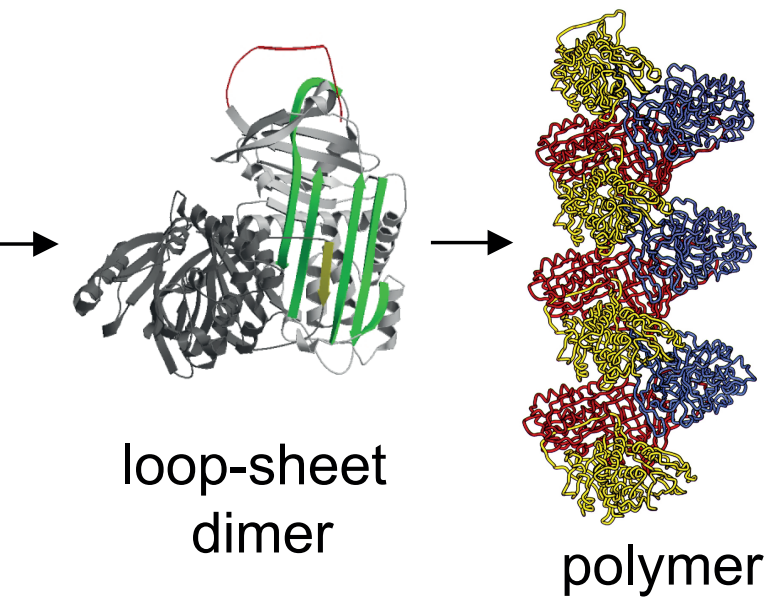

polymer

Pathway to serpin polymerisation

Ordered neuroserpin polymer inclusions

No UPR activation Polymer-induced calcium release NFKB activation

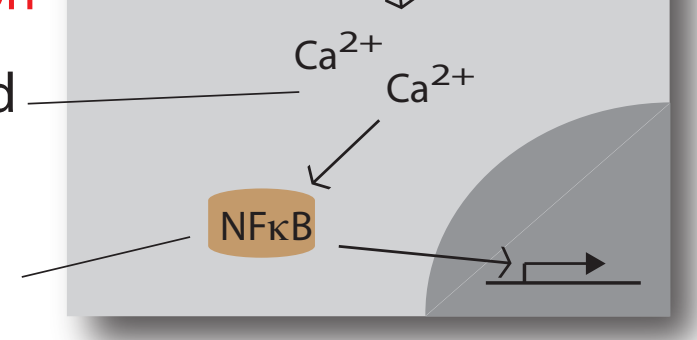
ER overload response 